أثر الوظائف الخضراء لإدارة الموارد البشرية على التنمية المستدامة: دراسة تطبيقية على فروع بنك

\title{
القاهرة بمحافظة الاسكندرية
}

ملخص البحث: إن الهدف الرئيس للبحث هو التعرف علي أثر الوظائف الخضراء لإدارة الموارد البشرية على التنمية

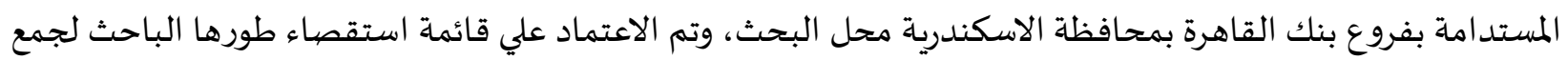

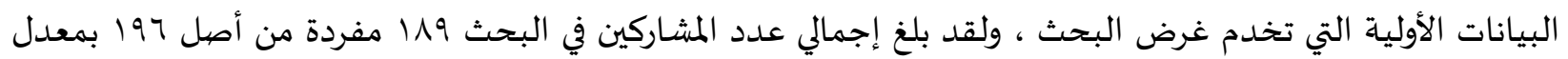

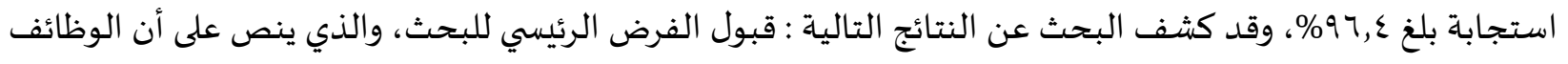

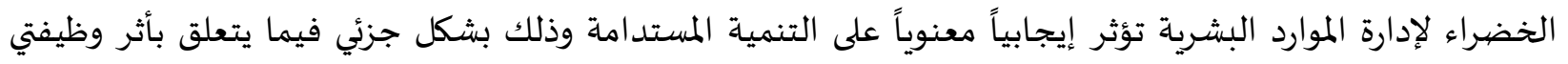

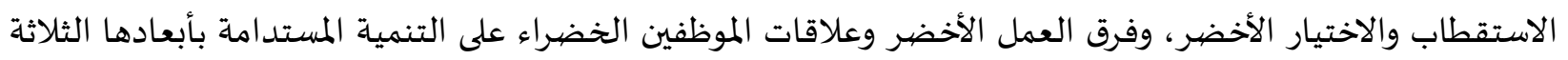

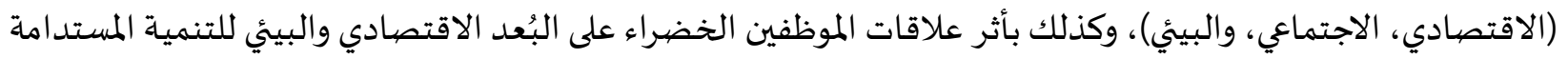

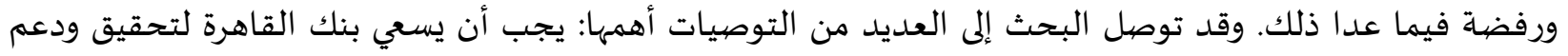

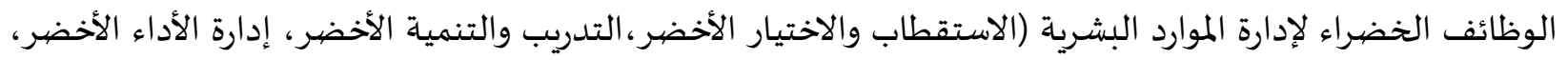

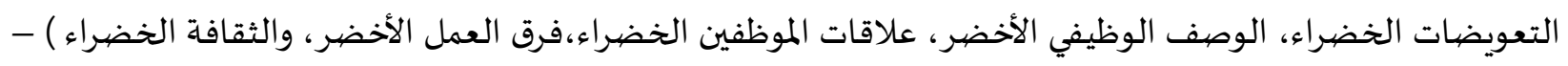

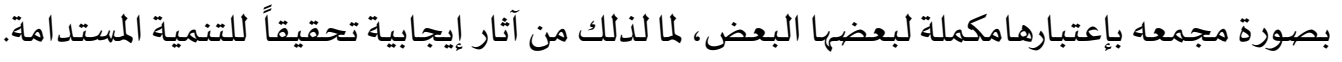

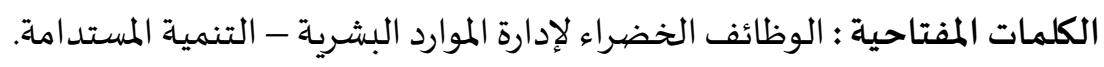

The Effect of Green Human Resources Management Functions on Sustainable Development: An Applied Study on Banque du Caire branches in Alexandria Governorate

Abstract :The main objective of the research is to identify the impact of green human resource management functions on sustainable development in the Banque du Caire branches in the Alexandria governorate. A survey list developed by the researcher was used to collect primary data that serve the purpose of the research. Total number of study participants is 189 out of 196 with a response rate of $96.4 \%$ The research revealed the following results: Accepting the main hypothesis of the research, which states that green human resource management functions have a positive significant impact on sustainable development partially in relation to the impact of the green recruitment and selection functions, green teams and green staff relations on sustainable development in its three dimensions (economic, social, and environmental), as well as the effect of green staff relations on the economic and environmental dimension of sustainable development and its rejection otherwise. The research reached many recommendations, the most important of which are:Banque du Caire should strive to achieve and support green human resource management functions (green recruitment and selection, green training and development, green performance management, green compensation, green job description, green staff relations, green teams and green culture) collectively as complementary to each other with the positive effects in order to achieve sustainable development.

Keywords: Green Human Resource Management GHRM functions - sustainable development. 
تلعب إدارة الموارد البشرية دوراً رئيسياً فى التنمية كما يمثل الإستثمار فهيا أفضل الإستثمارات عائداً، وتأتي أهمية الموارد البشرية من المحور الأساسي لنشاطها والذي يتمثل فى الإنسان فهو مصدر كل الثروات وعليه تعتمد الكفاءة والنمو والتقدم التمان وكيان المنظمة واستمرارها فى المنافسة. وحتى يستطيع العنصر البشري فى المنظمة القيام بواجباته بكفاءة وفعالية لا بد من إدارته بالصورة المثلي حتي تستطيع المنظمة تحقيق انتاجية أعلي أهدافها الاستراتيجية، تتأثر إدارة الموارد البشرية بالمتغيرات البيئية بطريقة أو بأخري التى تحدث في بيئة المنظمة ومن ثم كان لزاماً مواجهة المتغيرات الخارجيه المؤثرة على الأفراد من خلال

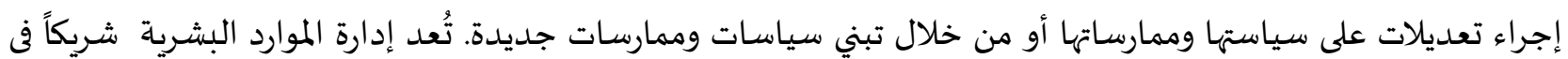

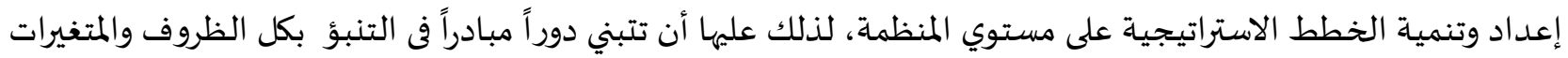

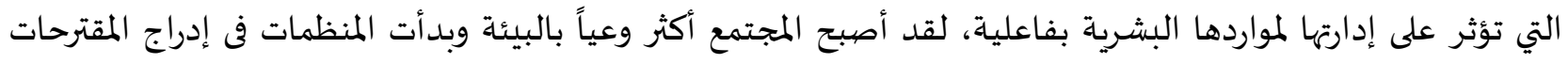

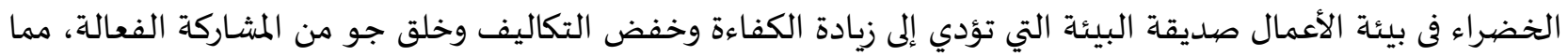
يساعد على العمل بطريقة مستدامة بيئياً لذلك فقد أصبح من الضروري الاهتمام بالمخاوف البيئية وهي قضية مهمة في الوقت الحاضر ، وأن كل صناعة تعمل على إعداد وتنفيذ ممارسات صديقة للبيئة للحد من القضايا البيئية. في إدارة الموارد البشرية يتم وضع وظائف خضراء من أجل تقليص نسبة الضرر أو الخسائر النسبية لمواردها من أجل التوسع في المستقبل لكل Jaid,. \& Misal, (2019)(إعناعة إلى جانب المورد البشري أيضًا الوظائف الخضراء هي برامج فعلية لإدارة الموارد البشرية الخضراء وتطبقها المنظمات كتقنيات وعمليات لتقليل الآثار السلبية للبيئة والمجتمع، ودعم الجوانب الإيجابية، إذ أن الهدف والغاية هو الاستدامة للأداء البيئي والاجتماعي بالإضافة إلى الأداء الاقتصادي، وفي السياق العالمي اليوم هذا ما تطبقه العديد من المنظمات، وللعيش في ظل أنظمة بيئية سليمة، تحتاج إلى

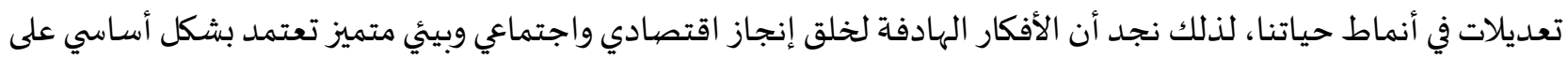
عنصر رأس المال البشري، من خلال التوعية المستمرة والتي تسعي إلهها المنظمات التي تهتم بالوظائف الخضراء، لقد حظي مجال البحث للوظائف الخضراء لإدارة الموارد البشرية على الاهتمام في السنوات الأخيرة، فالوظائف الخضراء تدفع بالعاملين إلى إنجاز أكبر من المتوقع حيث تُعرف بأها وظائف موجهة نحو التخضير تساعد في استدامة البيئة وخلق منصية من الخبرات للقوي العاملة عالية الرضا الوظيفي مما سيؤدي إلى إنتاجية عالية (2015),Arulrajah et al. وفى ضوء التحولات التي يشهدها القرن العشرون ظهرت مبادرة التنمية المستدامة وهى تعتبر واحدة من أهم الأفكار التى انتشرت خلال الفترة الأخيرة حيث بدأ (2011) Human Development Report. لبرنامج الأمم المتحدة الإنمائي مؤكدًا على أن الاستدامة هي قضية عدالة اجتماعية لأجيال الحاضر والمستقبل على السواءوتعتبر التنمية المستدامة عملية شاملة تهدف إلى إيجاد سبل ووسائل تضمن الانتقال من حالة التخلف الاقتصادى والاجتماعى للدول إلى وضعية أكثر ازدهارًا تسودها الرفاهية وتحسن المستوى المعيشي،حاضراً ومستقبلاً، يرتبط فهم مفهوم التنمية المستدامة من الناحية النظرية بالاستدامة البيئية -

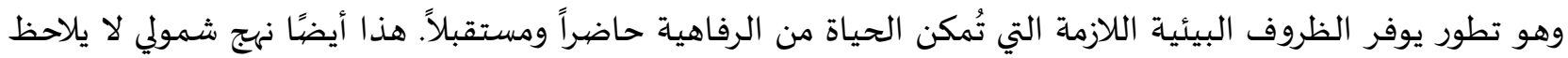


التنمية المستدامة منفصلاً عن حماية البيئة ويوضع في سياق اجتماعي واقتصادي. ومع ذلك، من أجل تحقيق الظروف البيئية Klarin,. اللازمة، يجب أيضًا تحقيق بعض الظروف الاجتماعية بالنظر إلى أثرها أو عدم أثرها على الاستدامة البيئية (2018) ومن جانب آخر نجد أن الخدمات المصرفية هي واحدة من قطاع الخدمات في مصر، تنمو وتتحمل قدراً كبيراً من المسؤولية الاجتماعية والمالية، يدرك القطاع المصرفي المصري أهمية كل من الأخلاق الاجتماعية والشعور الأخضر بالموثوقية البيئية. القطاع المصرفي ليس فقط أداة لبناء العلامة التجارية، ولكنها توسع ليصبح الأداة الأساسية للخدمات المصرفية. وقد أصببحت وظائف الموارد البشرية حالياً تأخذ المبادرة في القطاع المصرفي أيضًا لمواءمة ممارساتها وسياساتها مع أهداف الاستدامة التي. إن إدارة الموارد البشرية الخضراء هي عملية لتطوير سياسة الإدارة البيئية والتي بموجبها يتعين على البنوك ربط التوازن بين تنمية المصرفي الإلزامي وسلامة البيئة الطبيعية للجيل القادم. إدارة الموارد البشرية الخضراء ليست سوى "تخضير" البعد الوظيفي لإدارة الموارد البشرية مثل تصيميم الوظائف وشراء الموارد البشرية .تعلن إدارة الموارد البشرية الخضراء عن استخدام كل ميزة لدى الموظفين والاستفادة منها مما يساعد على تشجيع الممارسات المستدامة وزيادة يقظة الموظف والالتزامات المتعلقة بمسائل الاستدامة. يتمثل التركيز الرئيسي في القطاع المصرفي والبدء في اتباع ممارسات مبتكرة في التشغيل الأمثل للموارد مع استهلاك Jaid,. \& Misal, أقل من الوقت، مما يؤدى إلى فاعلية التكلفة (2019) علي ضوء ما سبق ، وبما أن القطاع المصرفي هو جزء من النظام المالي تتحول البنوك إلى قوة مالية، بالإضافة إلى ذلك، فإن التوجاه نحو القطاع المصرفي يؤدي إلى زيادة معدلات النمو الاقتصادي في أي دولة. وبغرض تحقيق استدامة للمنظمات فى ظل بيئة أعمال تتسم بالتنافسية الشديدة فلابد من الاهتمام بالتطبيق السليم للوظائف الخضراء للموارد البشرية لتحقيق \&Moraes, et al. (2018 \&Maeen. (2018) \& Jaid, \& Misal,. (2019)(أهداف المنظمة، حيث أوضحت بعض الدراسات مثل \& Chanderjeet (2017 Sunita,. (2017)) والاجتماعي والاقتصادي، بالإضافة إلي أنها تؤثر على رضا الموظفين إيجابياً، ومن ثم تحسين أداء المنظمات.على الرغم من أهمية الوظائف الخضراء لإدارة الموارد البشرية إلا أن معظم الدراسـات التى تناولتها لم تربطها بمدي علاقتها بشكل مباشر بالتنمية المستدامة، لذلك تناول الباحث فى هذا البحث التعرف علي أثرالوظائف الخضراء لإدارة الموارد البشرية في تحقيق التنمية المستدامة كدراسة تطبيقية علي فروع بنك القاهرة بمحافظة الاسكندرية

\section{r - الإطارالنظري والدراسـات السـابقة}

تتمثل محاور البحث في كل من إدارة الموارد البشرية الخضراء ووظائفها والتنمية المستدامة، وعليه فإن المناقشة للإطار النظري والدراسات السابقة ستدور حول هذه المحاور كما يلي:

ب-1 إدارة الموارد البشرية الخضراء تعددت التعريفات المقدمة لتعريف إدارة الموارد البشرية الخضراء حيث عرفها (2008),.Renwick et al بأهها عبارة عن دمج الإدارة البيئية للمنظمات في وظائف إدارة الموارد البشرية، بالإضافة إلى أن السياسات المتميزة في مجال الاستقطاب، وإدارة الأداء والتقييم، والتدريب والتطوير، وعلاقات العمل، والأجور والمكافآت تعتبر أدوات قوية لتوافق العاملين مع الاستراتيجية البيئية للمنظمة، وعرفها (2013) Jabbour, بأنها المواءمة المنهجية والمخططة لوظائف إدارة الموارد البشرية النموذجية مع 
الأهداف البيئية للمنظمة. بالإضافة إلى أن سياسات إدارة الموارد البشرية تستخدم لتشجيع الاستخدام المستدام للموارد داخل المؤسسات التجارية وتعزيز القضايا البيئية التي تعزز من معنويات العاملين وتحقق رضاءهم. فى حين تم تعرفها وفقاً لدراسة (2010), Jabbour et al بأنها جعل الأبعاد الوظيفية لإدارة الموارد البشرية خضراء مثل الوصف الوظيفي، والاستقطاب والاختيار، والتدريب ، وتقييم الأداء، والمكافآت. أما Rani\& Mishra,(2014 استخدام سياسات إدارة الموارد البشرية لدعم الاستخدام المستدام للموارد داخل المنظمات، والذي يُعد من أهم الأسباب التي تساعد استدامة البيئة، في حين عرفها ( Rimi\& 2015), Yusoff عملية واسعة منظمة من تطبيق للابتكار لتحقيق الاستدامة، وخفض النفايات والمسؤولية الاجتماعية والميزة التنافسية، وأخيراً عرفها (2016) Sarode et al، وظائف الموارد البشرية الموجهة نحو التخضير ويسهم في استدامة البيئة وتسهم فى خلق منصة من الخبرات للقوي العاملة عالية الرضا الوظيفي مما سيؤدي إلى إنتاجية عالية، وبناءً لما سبق فقد

اتضح بعض المفاهيم الخاصة ببعض الباحثون حول إدارة الموارد البشرية الخضراء يوضحها الجدول رقم (1).

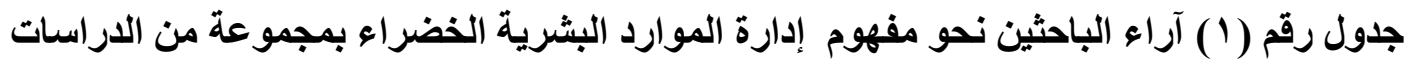

\begin{tabular}{|c|c|}
\hline مفهوم إدارة الموارد البشرية الخضراء & 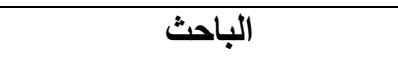 \\
\hline 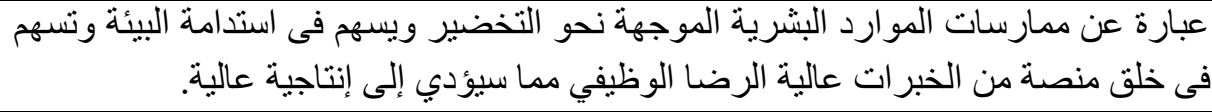 & Sarode et al ,(2016) \\
\hline عملية و اسعة منظمة من تطبيق للابتكار و المسؤولية الاجتماعية و الميزة التنافسية & Rimi\& Yusoff ,(2015) \\
\hline 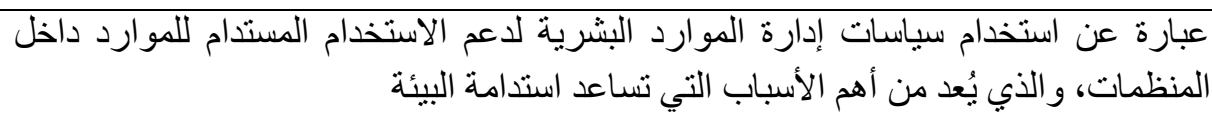 & ,(2014) \\
\hline 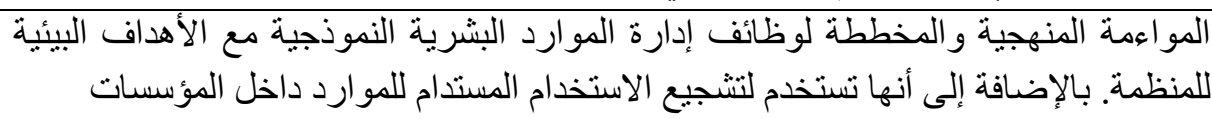 & Jabbour,(2013) \\
\hline 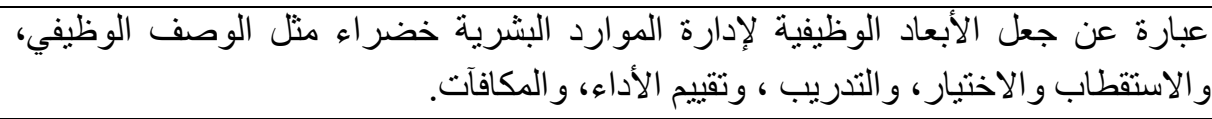 & Jabbour et al ,(2010) \\
\hline 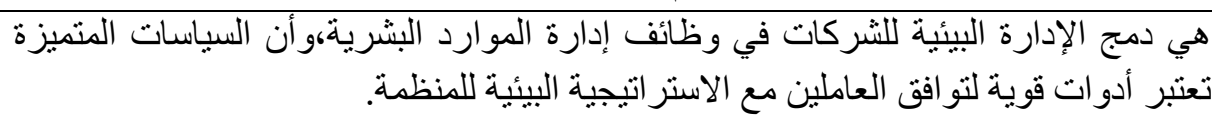 & Renwick et al.,2008) \\
\hline
\end{tabular}

المصددر: إعداد الباحث من خلال الاعتماد على المصيادر المتوفرة لدورة

وفي ضوء التعريفات السابقة نجد أنه تعددت وجهات نظر الأدبيات فى تعريف إدارة الموارد البشرية الخضراء بناءاً على الوظائف التى تم استخدامها، وبناءً عليه اعتمد البحث الحالي على تعريف إدارة الموارد البشرية الخضراء بأهها" إدارة تهتم بالتطور موجهة نحو البيئة المحيطة بالمنظمة الخاصة والعامة من خلال الاهتمام بالعنصر البشري الذي يتميز بالمهارة، والعمل علي دمج للسياسات المتميزة من خلال وظائفها الخضراء لتشجيع الاستخدام المستدام للموارد بهدف تعزيز

القضيايا البيئية التي تعزز من_معنويات العاملين وتعمل على التو افق بين العاملين والأهداف الاستر اتيجية للمنظمة". الوظائف الخضراء لإدارة الموارد البشرية التميز في السياسات والإجراءات في وظائف إدارة الموارد البشرية للمديرين والعاملين في بنك القاهرة من (التصميم الوصفي الأخضر، الاستقطاب والاختيار الأخضر، ادارة الاداء الأخضر، المكافأت والتعويضات الخضراء، ومشـاركة الموظفين الخضراء، فرق العمل الخضراء، الثقافة البيئية الخضراء)، والتي تعتبر الأداة القوية الفاعلة في توجيا العاملين نحو الأداء البيئي وهي العمليات والبرامج الخضراء والتقنيات التي تُنفذ للحد من الآثار السلبية، والاهتمام بالآثار الإيجابية تحقيقاً للأداء المستدام. 
ويتباين الباحثون في تحديدهم للوظائف التي يجب أن تتضمنها إدارة الموارد البشرية الخضراء، ويوضح الجدول التالي رقم (r) الوظائف الخضراء لإدارة الموارد البشرية الواردة في بعض الدراسات والأدبيات البحثية.

جدول رقم(r) الوظائف الخضراء لإدارة الموارد البشرية بمجموعة من الدراسـات

\begin{tabular}{|c|c|}
\hline وظائف إدارة الموارد البشرية الخضراء & 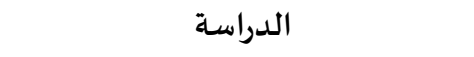 \\
\hline 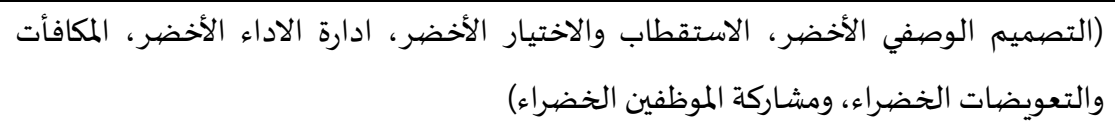 & Jaid, \& Misal, (2019) \\
\hline 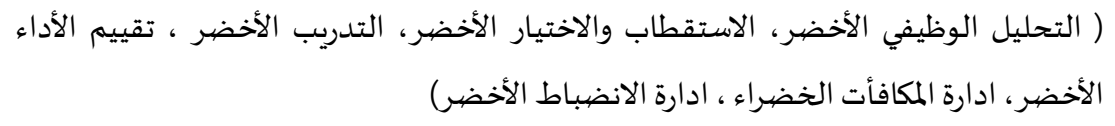 & Maeen. (2018) \\
\hline (التدريب البيئي ، والتمكين البيئي ، العمل الجماعي للأغراض البيئية، الأداء ذو الكفاءة البيئية) & Moraes, et al. (2018) \\
\hline 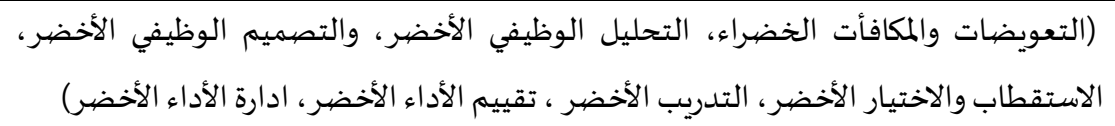 & Halawi, \& Zaraket,(2018) \\
\hline الأخضر، الوصف الوظيفي الأخضر، التحليل الوظيفي الأخضر، الاستقطاب والاختيار الأخضر، التدريب ، الأخضر ، المكافأت الخضراء) & John, \& Sathiq, (2018) \\
\hline الخضراء، مشاركة الموظفين الخضاب والاختيار الأخضر، المكافأت، التدريب البيئي، فرق العمل الخضراء، الثقافة البيئية & Sunita, (2017) \\
\hline 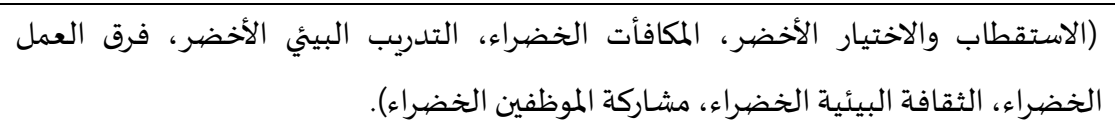 & Chanderjeet (2017) \\
\hline (الاستقطاب والاختيار الأخضر ، التدريب الأخضر، تقييم الأداء الأخضر، التعويضات الخضراء) & Rimi, (2016) \\
\hline
\end{tabular}

المصدر: إعداد الباحث من خلال الاعتماد على المصيادر المتاحة

وفى ضيوء الكتابات والأدبيات البحثية التى تناولت الوظائف الخضراء لإدارة الموارد البشرية والتى يتضح منها وجود اختلافات بين الكتاب والباحثين فى تحديدهم للوظائف الخضراء لإدارة الموارد البشرية فتم اختيار الوظائف الخضراء لإدارة الموارد البشرية الأكثر شيوعاً في الدراسات وتتمثل فيما يلي: المتمثلة (الاستقطاب والاختيار الأخضر، التدريب والتنمية الأخضر، إدارة الأداء الأخضرر، التعويضات الخضراء، الوصف الوظيفي الأخضر، علاقات الموظفين الخضراء، فرق العمل الخضراء، والثقافة الخضراء )، ويمكن توضيح هذه الوظائف فيما يلي:

\section{(1) الاستقطاب والاختيار الأخضر}

الاستقطاب الأخضر يعني عملية التوظيف غير الورقية بأقل أثر على البيئة. وهو نظام يتم التركيز فيه على أهمية البيئة وجعلها عنصرًا رئيسيًا في الصناعة المصرفية. بالإضافة إلى ذلك، فإن هؤلاء الأفراد يتم تحريكهم أيضًا وهم متحمسون للعمل في صناعة مصرفية خضراء صديقة للبيئة. إن استقطاب المرشحين ذوي التطور الأخضر يجعل من السهل على البنوك تثقيف المهنيين الذين يدركون العمليات المستدامة مثل إعادة التدوير والحفظ وخلق عالم أكثر منطقية من خلال البيانات يمكننا أن 
نستنتج أن الاستقطاب الأخضر يوفر لصاحب العمل زيادة الفرصة في جذب المرشحين والاحتفاظ بهم بعد الترشيحات. في الآونة الأخيرة، يجعل الاتجاه الأخضر موضوعات الاستقطاب كقضايا صديقة للبيئة، وبالتالي يجعل الموظف صديقًاً للبيئة في تحقيق الأهداف البيئية وكيف ينظر الموظفين إلى الوظيفة ومعايير الاستدامة على النحو المطلوب على سبيل المثال، يمكن القيام بعملية الاستقطاب والاختيار في صورة مقابلات شخصية غير ورقية ومواقع صديقة للبيئة وأيضًا ممارسات أخرى في التوظيف. يمكن للقائمين على الاستقطاب تنفيذ السياسات الخضراء وكذلك سياسات الإدارة في وضع السياسات الخضراء Chanderjeet (2017) لتحقيق الأهداف (r) (r) التدريب والتنمية الأخضر

يعد تعليم وتدريب القوى العاملة عنصرين أساسيين في تعزيز وتنفيذ ممارسات الإدارة البيئية في منظمات الأعمال. إن عوامل الموارد البشرية مثل دعم الإدارة العليا والتدريب البيئي وتمكين الموظفين والعمل الجماعي وأنظمة المكافآت هي عناصر أساسية في عملية تنفيذ وصيانة نظام الإدارة البيئية. التدريب البيئي مناسب للمديرين وغيرهم من الموظفين، حيث يظهر الموظفون تدريهه وتأهيلهم من خلال العمل الجماعي. التدريب البيئي هو العامل الأكثر أهمية، فبدون تدريب محدد لا يتم تحقيق مستويات عالية من التنمية البيئية، والتي ينبغي أن تكون أولوية للمنظمة التي تريد أن تظل قادرة على المنافسـة. يؤثر التدريب البيئي بشكل إيجابي على تطوير الاستراتيجيات البيئية الاحترافية، أن تدريب الموظفين حسب الطلب له أثر مباشر وإيجابي على أداء المنظمات في التنمية المستدامة ويعدل إيجابياً العلاقة بين الموقف البيئي للمنظمة وأدائها في التنمية. أظهرت بعض إلى الدراسات أن المنظمات التي تقدم المزيد من التدربب يمكن أن تحقق فعالية أفضل في عمليات الإدارة البيئية وأن جميع المستويات الهرمية للموظفين يجب أن تتلقى تدريبًا بيئيًا لزيادة الوعي والمعرفة. وأنه يتعين على المنظمات إنشاء بيئة أعمال Moraes, et al (2018) تتميز بمستويات عالية من الوعي البيئي والتوجياه وتوفير التدريب البيئي الكافي لزيادة كفاءاتها البيئية (r) (إدارة الأداء الأخضر

إن إدارة الأداء هي عملية مستمرة للاتصال بين العاملين والمشرفين الذى يتم على مدار العام لكي يدعم الأهداف الاستراتيجية للمنظمة، وتشتمل إدارة الأداء الأخضر كافة الأمور المتصلة بسياسات المنظمة والمسؤوليات البيئية. ويؤدي إدماج الإدارة البيئية في إدارة الأداء إلى تحسين قيمة ونوعية الأداء البيئي، حيث أشارت دراسة (Jabbour et al.,2008) ، إلى أن إدارة الأداء تهدف إلى تحسين الأداء بشكل عام، وذلك من خلال مقارنة النتائج مع الأهداف والتى تسعي لتحقيق أهداف المنظمة على المدي البعيد. بالإضافة إلى أن إدارة الأداء الأخضر في ضوء رؤية الإدارة البيئية تعني أن المنظمة تقوم بتقييم الأداء البيئي للعاملين ومساهمتهم فى تحقيق النتائج البيئية داخل المنظمة، وتم التأكيد على أن إيجاد مؤشرات الأداء الأخضر تعني إنشاء العديد من المعايير لجميع الأعضياء فى تقييم الأداء، تغطى عدة موضوعات مثل الحوادث والمسؤوليات البيئية، وتقديم الاهتمامات والسياسـات البيئية، كما تؤكد بعض الدراسات فى هذا الصدد على أن مؤشرات الأداء الأخضر لا غني عنها للمديرين والعاملين على حد سواء حيث يعتبر تقييم الأداء من أهم الجوانب المؤثرة على عملية وفعالية إدارة الأجور والمكافآت، لذلك لا غني عن

تلك المؤشرات فى نظم إدارة الأداء (2017) Tang., et al., 


\section{(ع) التعويضات الخضراء}

يشير نظام الأجور والمكافآت إلى مجموعة التدابيرالمجزية من أجل جذب العاملين والمحافظة عليهم وتحفيزهم،. ويمثل نظام الأجور والمكافآت الخضراء وظيفة رئيسية من الوظائف الخضراء لإدارة الموارد البشرية حيث تعتمد استدامة الأداء البيئي للمنظمة اعتماداً كبيراً على ممارسات إدارة الأجور والمكافآت الخضراء لتحفيز المديرين والعاملين على مبادرات الإدارة البيئية للمنظمات، يتم ذلك عن طريق إعطاء حوافز مالية للموظفين لأدائهم الأخضر الجيد في الوظائف بجانب المكافآت غير المالية مثل المدح والتقدير للموظفين بسبب اتباعهم الممارسات الخضراء. يمكن أن يضع قسم الموارد البشرية توصيفًا وظيفيًا للإدارة البيئية الخضراء عند للموظفين. بالإضافة إلى ذلك، ينبغي إدراج الأهداف الخضراء في توصيف الوظائف الإدارية. في خطتها الإستراتيجية لتطوير نموذج المكافآت للمواهب، يمكن أن تدرج المنظمة الوعي البيئي كأحد الكفاءات الأساسية المطلوبة من الموظفين، وتستطيع المنظمات التي لديها ممارسات خضراء جذب المواهب الجيدة، وإعطاء الأفضلية في الاختيار للمرشحين Halawi, \& Zaraket. (2018). الذين هم "على دراية بالبيئة"، والتي تصبح جزءًا من اكتساب الموارد البشرية (0) الوصف الوظيفي الأخضر بشكل عام، يمكن استخدام توصيف الوظائف لتحديد عدد من المهام والواجبات والمشئوليات المتعلقة بحماية البيئة. وفي هذه الأيام، قامت بعض المنظمات بدمج المهام والواجبات والمسئوليات البيئية والاجتماعية قدر الإمكان في كل وظيفة من أجل حماية البيئة. في بعض المنظمات، يشتمل كل وصف وظيفي على واجب واحد على الأقل يتعلق بحماية البيئة، ويشمل أيضًا على وجاه التحديد المسئوليات البيئية كلما كان ذلك ممكنًا. قد تشمل الأوصاف الوظيفية ومواصفات الأشخاص الوظيفية المتطلبات البيئية والاجتماعية والشخصية والفنية للمنظمات قدر الإمكان. على سبيل المثال، يجب تضمين مهام حماية البيئة إلى جانب تخصيص أدوار إعداد التقارير البيئية ومهام الصحة والسلامة. بالإضافة إلى ذلك، تستخدم بعض الشركات فرق Hussain,. العمل والفرق متعددة الوظائف كتقنيات تصميم الوظائف لإدارة المشكلات البيئية بالمنظمة بنجاح.. (2018)

\section{(7) علاقات الموظفين الخضراء}

تعتمد علاقات الموظفين على المشاركة الفعالة ومشاركة الموظفين في وظائف وعمليات اتخاذ القرارات التنظيمية. من الواضح أن مشاركة الموظفين في المبادرات التنظيمية الخضراء تؤدي إلى تحسين إدارة البيئة من خلال مواءمة تحفيز الموظفين وأهدافهم وقدراتهم مع ممارسات الإدارة الخضراء. إن إشراك الموظفين يحسن أنظمة الإدارة البيئية مثل الاستخدام الكفء للموارد وتقليل أي نوع من النفايات في المؤسسة. يعد بناء ثقافة إيجابية لإشراك موظفيها في أي عملية للإدارة البيئية أمراً بالغ الأهمية في تحقيق مبادرات الإدارة البيئية في المنظمة. كما قد يكون الأمر، فإن مبادرات الإدارة البيئية ليست مسئولية الإدارة العليا وحدها، بل المسؤولية المشتركة والتزام الجهات الفاعلة في موظفي المنظمة والعملاء والإدارة يجب أن يكون الموظفون على دراية بالأمور الخضراء في المنظمة، والتي تتطلب قنوات اتصال متنوعة وبيئة تعليمية خضراء. الرؤية الخضراء هي نمط المبادئ التي تلهم السلوك الأخضر، كما يوجاه الأفراد نحو المشاركة في أنشطة صديقة للبيئة. مثل هذه البيئة تلهم الأفراد ليكونوا على دواية بسلوك بعضهم البعض فيما يتعلق بالمبادرات الخضراء. ويمكن للأفراد تطوير سلوكياتهم وعيهم الأخضر (2019). 


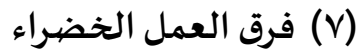

العمل الجماعي هوالعمل الذي يتضمن الأهداف والغايات المشتركة والثقة المتبادلة وصنع القرار بالإجماع والتعاون والتنسيق والتماسك. في سياق الإدارة البيئية في المنظمات، يأتي مفهوم الفرق الخضراء على أهها مجموعة العمل المصمممة لحل المشكلات البيئية. إن استخدام الفرق الخضراء هو أداة لتوجيه المنظمات الحاصلة على شهادات المواصفات المعتمدة نحو التخضير، تؤثر الفرق الخضراء بشكل إيجابي على أداء المنظمة وسمعتها البيئية، مما يساهم في تحسين الأداء البيئي التشغيلي وكذلك العلاقة الإيجابية بين الأداء البيئي والتنظيمي للموظف. يرتبط الأداء التنظيمي بالعمل الجماعي. يتم استخدام الفرق الخضراء

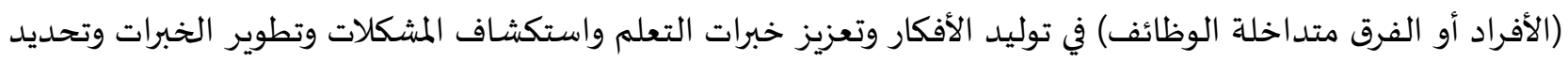

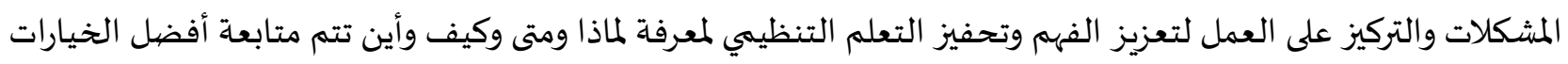
البيئية العملية للمنظمات؟. إنشاء فرق خضراء بين الموظفين في كل قسم سيساعد على تحديد المشكلات الخضراء، وتوفير حلوًا محددة للمشاكل، مما يجعل المؤسسة تعمل أكثر استدامة من الناحية البيئية. تقوم هذه الفرق بتثقيف وتمكين

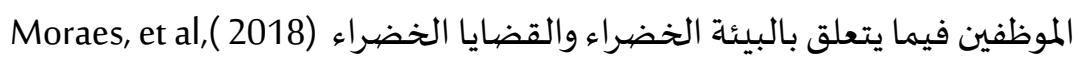
( ) ( ) ( الثقافة الخضراء

هناك موضوع قوي في الاستدامة على المدى الطويل وهو الثقافة الخضراء، أي الانسجام البشري والبيئي الأوسع معًا، بحيث البـاء يمكن تحقيق التنمية المستدامة للثقافة البشرية. الثقافة الخضراء هي خلق تبني الإنسان للبيئة. تساعد ممارسات الموارد

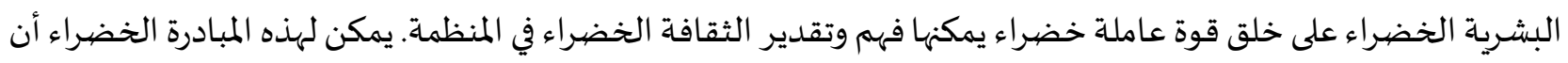

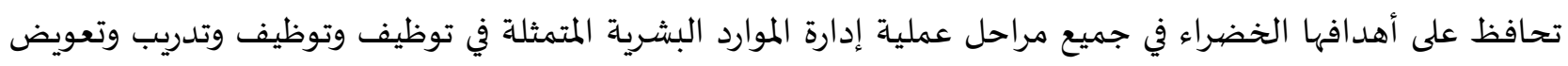
وتطوير ودفع عجلة رأس المال البشري للشركة. توجد مجموعة من محفزات الثقافة الخضراء التي حددتها دراسة إداءة Margaretha and Saragih (2013) وهي تطوير المواهب من أجل معرفة ممارسات "التخضير" بالمنظمات وتصميم الوظائف

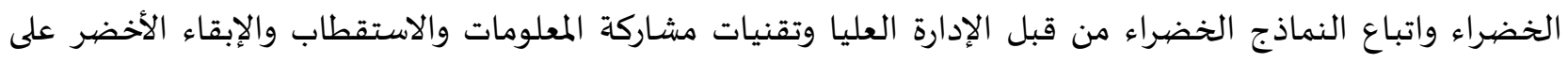

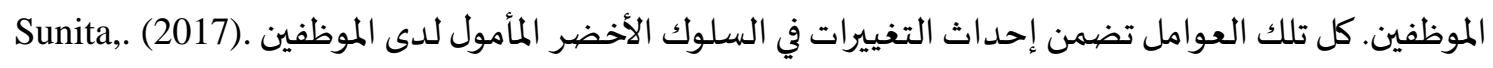

Y r T التنمية المستدامة ( مفهوم وأهداف، و أبعاد)

\section{مفهوم وأهداف التنمية المستدامة}

يمكن تناول التنمية المستدامة بتعريفات عديدة، ولكن قبل التعرف على مفهومها بشكل واضح لابد وأن نتطرق إلى ثلاثة مفاهيم رئيسية، لعل أول هذه المفاهيم هو النمو، والذى يعرف بأنه" الزيادة في الدخل الحقيقي"، ولكى نشعر بتلك الزيادة

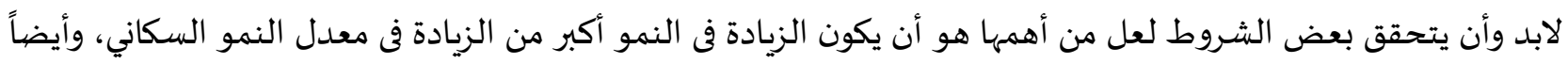

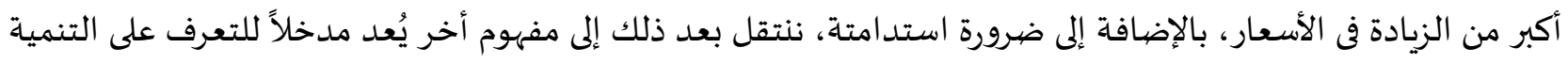

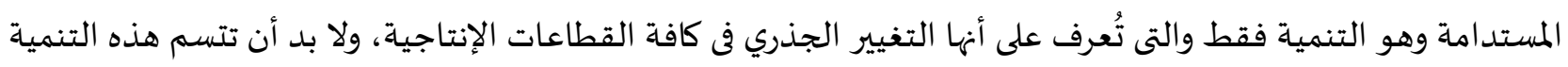

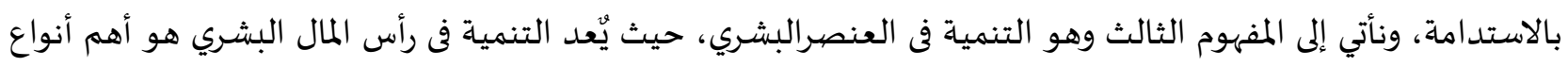

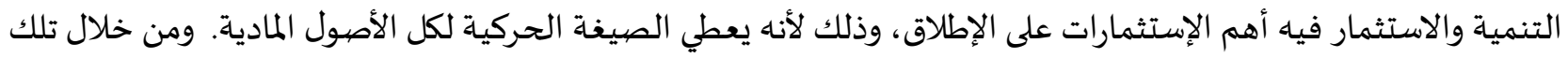


التعريفات السابقة المرتبطة ارتباط وثيق بالتنمية المستدامة يتضح لدينا أهها تُعرف بـ" تلبية احتياجات الحاضر بشرط المحافظة على احتياجات الأجيال المقبلة، وأن يعيش الإنسان مع الطبيعة وليس على حسابها" كما يمكن أن تُعرف بأهها عبارة عن " الحفاظ على جودة حياة الإنسان حاضراً ومستقبلاً ويتطلب زيادة النمو، وحماية البيئة، والإهتمام بجانب الصحة للأجيال الحالية والمستقبلية على حد سواء" ولقد أكد (2015) .Darwish على أن التعريف الأكثر انتشارًا للتنمية المستدامة هو التعريف الذي تضمنه "Brundtland Report عام 19NV" بعنوان "مستقبلنا المشترك" بأهها "تلبية احتياجات الحاضر بدون الأثر في قدرة الأجيال المقبلة على تلبية احتياجاتها". وأضافت Whitfield, 2015) تعريفًا آخر بأهها" حماية قدرة الأرض على دعم الحياة بكافة أشكالها المتنوعة بناء على مبادئ كل من المساواة بين الأنواع والتكافل واحترام الحقوق الأسـاسية مثل الحرية وتكافؤ الفرص للجميع".

وفي ضوء التعريفات السابقة نجد أنها تعددت وجهات نظر الأدبيات فى تعريف التنمية المستدامة وبناءً عليه اعتمد البحث الحالي على تعريف التنمية المستدامة على أهها "نظام لصنع القراروتحقيق صحة ورفاهية الإنسـان في الحاضروالمستقبل بناءعلى مبادئ المساواة الأساسية التي تقول أن كل إنسان مخصص له نوع معين من جودة الحياة،ويدب الحفاظ على الحد الأدنى من ظروف تلك الجودة من جيل لآخر".

ولقد تمثلت أهداف التنمية المستدامة فى القضياء على الفقر والجوع وتحسين التخذية، توافرالحياة الصحية السليمة، ضمان جودة التعليم، تعزيز فرص العمل، تحقيق المساواة، وتمكين المرأة، توافر الإدارة المستدامة للمياه والنظافة، الطاقة الجيدة، تعزيز استدامة النمو الإقتصادي وتعزيز التوظيف الكامل، توافر البنية التحتية القوية، تقليل اللامساواة، توافر الإستقرار الإنساني المستدام، مقاومة آثار التغيرات المناخية، المحافظة على موارد البحار والمحيطات، مقاومة التصحر وإيقاف خسائرالتنوع البيولوجي، تعزيز المجتمعات، تعزيز المجتمعات وتوفيرالعدالة داخل المجتمعات، تقوية وسائل تفعيل الشراكات للتنمية المستدامة عالمياً.ومن هنا تتلخص أهداف التنمية المستدامة بين الطموح والأهداف، حيث تركز أن تكون المجتمعات مزدهره تستمد ذلك من خلال زيادة النمو والذى يؤدي بدوره لرفع المستوي المعيشي ومن ثم تحقيق الرفاهية، وضمان الاستدامة، وتوفير بنية أساسية قوية لكونها العمود الفقري للتنمية المستدامة ، ومن ثم تعزيزا لاقتصاد القومي الذى يساعد على تحقيق مستوي أفضل من المعيشـة (2015) Basnett, \& Bhattacharya, ، يمكن تحديد ثلاثة أبعاد التي تقوم عليها عملية التنمية المستدامة حيث أن هناك شبا إجماع تؤكده معظم الدراسات والأبحاث فيما يتعلق بأبعاد التنمية المستدامة على أنها Schoolman et al, (2012) ثلاثة أبعاد مترابطة ومتداخلة فيما بينها وتتمثل في الأبعاد (الإقتصادية، الإجتماعية، والبيئية)

وفيما يلي عرض موجز لأبعاد التنمية المستدامة الأسـاسية:-

\section{البُعد الاقتصهادي للتنمية Economic Dimension Of Development}

قدم الباحثون مساهمات أساسية في النظرية الاقتصادية للاستدامة. تمثل نماذجهم الرفاه مع مرور الوقت لقد أظهروا الحد الأقصى لمستوى الفائدة الذي يمكن تحقيقه بمرور الوقت مع المستوى الهائي للموارد الطبيعية. قد يكون الأثر ثابتًا أو متناقصًا بمرور الوقت، اعتمادًا على ما يفترض حول رأس المال الأسساسي والتقدم التكنولوجي الذي يتم باه تخفيض الفائدة المستقبلية. على وجاه التحديد، أظهر Solow (عVI) أنه في ظل ظروف معينة، يمكن تحقيق رفاه دائم مع مرور الوقت من 
خلال الحفاظ على إجمالي رأس المال. وهذا يعني أن استنفاذ رأس المال الطبيعي يمكن القضاء عليه من خلال الاستثمار في رأس المال الصناعي أو أنواع أخرى منه. من خلال الحفاظ على مستوى رأس المال الإنتاجي، وهو أعلى مستوى ممكن ، يمكن تحقيق الاستهلاك للشخص الواحد مع مرور الوقت. على الرغم من أن Solow لم يتحدث صراحةً عن الاستدامة، كانت تلك هي أول ورقة يمكن قراءتها في سياق نظرية النمو الاقتصادي الرسمي كهدف مستدام للمجتمع تتمثل أبرز نقاط الاستدامة الاقتصادية في توفير حياة مستدامة للإنسان عبر القضاء على الفقر في الحياة والتكنولوجيا. لتحفيز تنمية المجتمع وتشجيع الناس على المشاركة في الاقتصاد(أبرز هذا العمل أهمية إنشاء بنى تحتية لتكنولوجيا المعلومات والاتصالات استنادًا إلى حقيقة أن تمكين الدول بتكنولوجيا المعلومات والاتصالات سيساعد على إنتاج ونشر المعرفة الجديدة، وبالتالي الاستفادة من إنتاجية الدولة وتسريع التنمية البشرية بجانب أنشطة الزراعة المستدامة والتكنولوجيا الذكية. النمو الاقتصادي المستدام والعمالة المنتجة والعمل اللائق، ففي القرن الحادي والعشرين، مع الشعور بالمسئولية البيئية والاجتماعية على نطاق واسع، أصبح خيارًا حتميًا للمؤسسات أن تتبنى مفاهيم التنمية المنهجية وتنفذ تطوير الاقتصاد الاجتماعي - الإيكولوجي. وبالتالي، لا يتعين على المؤسسات الاهتمام فقط بالإنتاجية وكفاءة الاستثمار، بل تحتاج أيضًا إلى مراعاة قضايا التنمية المستدامة. Wu, and Xiang, (2018) يري الباحث أن البعد الإقتصـادي يركز على مبدأ العدالة فى التوزيع للموارد بين الأجيال حيث يهتم بما يحقق إستدامة النمو، وذلك من خلال الإهتمام بنوعيتة حيث يجب قيام النمو بالحفاظ على البيئة ومواردها، ويفضل أن يكون مقترناً بخلق المزيد من فرص العمل، بما يؤدي إلى المسـاواة بين فئات المجتمع أوتقليل الفجوة بين زيادة الثروة والإفتقار، والعمل على تقليل العديد من المشاكل الإقتصادية التي تصيب المجتمع كإرتفاع معدلات التضخم أو إرتفاع معدلات البطالة، كما يجب أن يقوم النمو علي قدرات البشر، ومهاراتهم.

\section{Social Dimension Of Development البُعد الاجتماعي للتنمية}

تظهر الاستدامة الاجتماعية عندما تعزز الإجراءات والهياكل والجمعيات والتفاعلات بقوة قدرة الأجيال المعاصرة والقادمة على إنشاء مجتمعات صحية وقابلة للعيش. يتعلق البعد الاجتماعي أو مبدأ العدالة الاجتماعية في إطار التنمية المستدامة بجميع أعضاء المجتمع الذين لديهم وصول متساو إلى الموارد والفرص المتاحة. وهكذا، تشير الاستدامة الاجتماعية إلى الأنشطة التي تضمن أن تكون المجتمعات نزههة ومتنوعة وحليفة وتحكم ذاتيًا وتقدم قيمة نبيلة للحياة. من الحدة في تحديد التنمية المستدامة الاعتراف بأن "الاحتياجات" هي معاصرة ووشيكة الحدوث ويتب تحقيقها في بيئة منصفة. قد تعتبر الشركة أنها من المنطقي اجتماعيًا تقليد الشركات الأخرى، أي تبني سلوكيات عقلانية اجتماعيًا لتحقيق هذا التوازن المنشود. تركز الأنشطة الاجتماعية على المجتمع والرياضة والصحة والرفاهية والتعليم ومسـاعدة أصحاب الدخول المنخفضة والمشاركة في المجتمع. تعتبر هذه الأنشطة تدخلات من أجل تعزيز الأسباب الاجتماعية والثقافية في المجتمعات فضلاً عن تطوير المجتمع. بشكل عام، يتم قياس الاستدامة الاجتماعية من خلال المبادئ والإجراءات المنفذة (2019). Masocha. البعد الاجتماعي هو موضيوع رئيسي للتنمية المستدامة. تشارك الدولة أو المنطقة المجتمع بنجاح في تحديد الأهداف الإنمائية والبيئية، فهي ليست مستدامة بالضرورة. إذا كانت هذه المشاركة تؤدي إلى أهداف وسياسات سياسية تتعارض مع حدود الكواكب المحددة من قبل علماء 
الطبيعة أو تتعارض مع احتياجات الفقراء. تم تقديم رأس المال الاجتماعي كمؤشر للاستدامة في العقد الماضي. يحتاج المجتمع إلى مستويات عالية من الثقة، وعلاقات قوية وشبكات تعمل كأداة ترابط بين أفراد المجتمع من أجل تعزيز الأنشطة المفيدة الجماعية. تعمل الشبكات في مراحل اجتماعية متعددة وتوسع نطاق عملها من خلال التعاون مع الجهات المختلفة وأصحاب المصلحة. مقارنة بالإجراءات الخضراء، فإن الإجراءات المسئولة اجتماعياً تفيد أصحاب المصلحة الداخليين والخارجيين بشكل

مباشر لأن هدفه هو تعزيز رفاهية الناس. Bandara, (2018).

يري الباحث أن البُعد الإجتماعي هو البُعد الإنساني، وهو الذي يجعل من النمو وسيلة للإلتحام الإجتماعي ولعملية

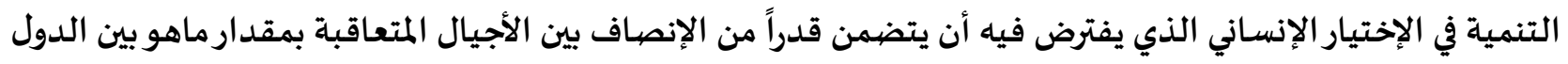

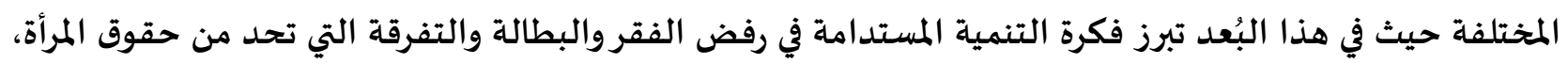

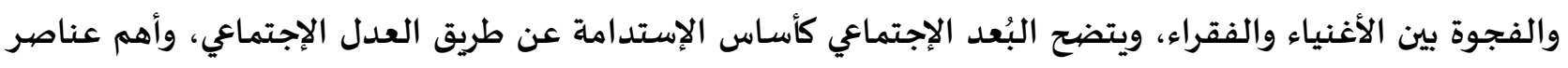

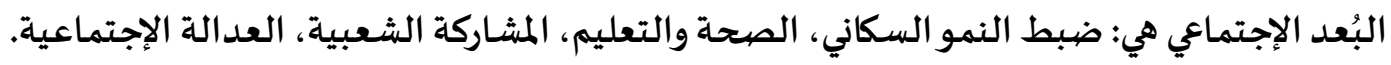

\section{البُعد البيئي للتنمية Environmental Dimension Of Development}

يدور مفهوم الاستدامة البيئية حول البيئة الطبيعية وكيف تظل مثمرة ومرنة لدعم الحياة البشرية. تتعلق الاستدامة البيئية بسلامة النظام البيئي وقدرة تحمل البيئة الطبيعية. يتطلب ذلك استخدام رأس المال الطبيعي بشكل مستدام كمصدر للمدخلات الاقتصادية وكحوض للنفايات. والنتيجة هي أنه يجب حصاد الموارد الطبيعية بشكل أسرع مما يمكن تجديدها بينما يجب أن تنبعث النفايات بشكل أسرع من البيئة التي يمكن استيعابها ، وذلك لأن أنظمة الأرض لها حدود أو حدود يتم فيها الحفاظ على التوازن. ومع ذلك، فإن البحث عن النمو المطلق يفرض متطلبات أكبر على النظام الأرضي ويضع ضغطًا أكبر على هذه الحدود لأن التقدم التكنولوجي قد يفشل في دعم النمو المتسارع. تتزايد الأدلة لدعم المخاوف بشأن استدامة البيئة. آثار تغير المناخ، على سبيل المثال، توفر حجة مقنعة للحاجة إلى الاستدامة البيئية. يشير تغير المناخ إلى تغييرات كبيرة وطويلة

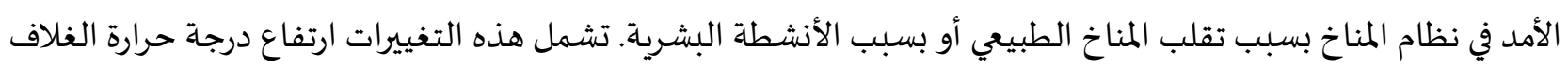
الجوي والمحيطات، وانخفاض مستويات الجليد، وارتفاع مستوى سطح البحر، وزيادة تحمض المحيطات وزيادة تركيزات الغازات الدفيئة. لقد أظهر تغير المناخ بالفعل علامات على التنوع البيولوجي. وقد لوحظ أن درجات الحرارة المرتفعة تميل إلى الأثر على توقيت التكاثر في الأنواع الحيوانية والنباتية وأنماط هجرة الحيوانات وتوزيعات الأنواع وأحجام السكان. جادلت دراسـة Ukaga et al (2011) بأنه على الرغم من كثرة التنبؤات، فإن التأثرات الكاملة للاحتباس الحراري غير معروفة. ما ينصح باه بوضوح، هو أنه من أجل الاستدامة، يجب على جميع المجتمعات أن تتكيف مع الحقائق الناشئة فيما يتعلق بإدارة النظم الإيكولوجية والحدود الطبيعية للنمو (2019) . Mensah.

يري الباحث أن جودة حياة الأفراد تتأثر بالسلب أو الإيجاب بفعل جودة البيئة، وقد يظهر ذلك الأثر بسبب عوامل معينة

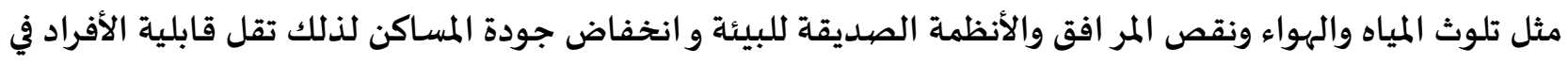

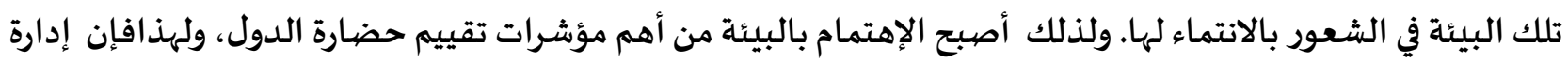

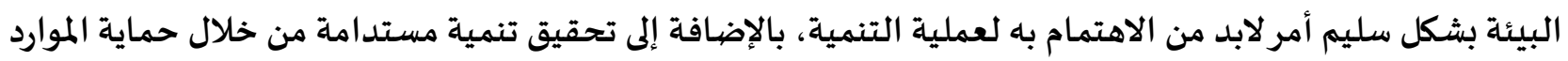

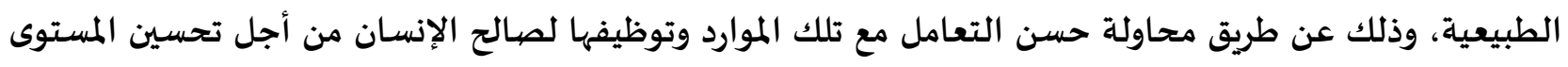


عند مراجعة الأدبيات البحثية المتعلقة بإدارة الموارد البشرية الخضراء، اتضح منها أنه من القضايا الهامه في الوظائف الخضراء لإدارة الموارد البشرية حيث الارتباط بالنواحي البيئية، وأن اعتماد الوظائف الخضراء لله علاقة إيجابية مع زيادة الأداء التنظيمي بالتالي يساعد على تعزيز صهورة المنظمة ، بالإضيافة إلى أهها تعطى الموظفين انطباعاً لأداء مهامهم بعناية وبأقل ضرر للبيئة مما يزيد من رفع الانتماء والولاء والثقة بين الموظفين. لذلك فسوف يتم تناول عدداً من الدراسات التجريبية السابقة التي تناولت وظائف إدارة الموارد البشرية الخضراء، حيث هدفت دراسة (2019) .التحقق من العلاقة بين وظائف الموارد البشرية الخضراء بأبعادها المتمثلة في (التصميم الوصفي الأخضر، الاستقطاب والاختيار الأخضر، ادارة الاداء الأخضر، المكافأت والتعويضات الخضراء، ومشاركة الموظفين الخضراء) والأداء التنظيمي من قبل موظفي بنك ICICI بالهند. تم إستخدام استبيان تم توزيعه على الموظفين والإداريين، وتوصلت إلى أن كل من التعويض والمكافآت وأداء الموارد البشرية الخضراء ومشاركة الموظفين لها علاقة إيجابية قوية بالمقارنة بعوامل أخرى مع الأداء البيئي. وكان الهدف من دراسة هو وضع أفكار إدارة الموارد البشرية الخضراء في أفعال بدلاً من تقديم رؤى واسعة حولها وهي موجودة

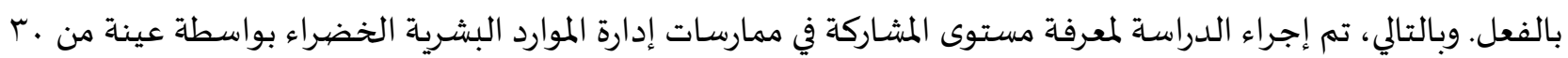
مصرفًا تجاريًا يعمل في بنجلاديش بنوك خاصة وعامة ، وكانت موجهة نحو مدراء ادارة الموارد البشرية فى هذه البنوك. تشمل نتائج الدراسة مستوى ممارسات إدارة الموارد البشرية الخضراء ( التحليل الوظيفي الأخضر، الاستقطاب والاختيار الأخضر، التدريب الأخضر، تقييم الأداء الأخضر، ادارة المكافأت الخضراء ، ادارة الانضباط الأخضر) وجدت هذه الدراسة أن اعتماد الممارسات الخضراء لله علاقة إيجابية مع زيادة الأداء التنظيمي ويساعد على تعزيز صورة المنظمة. بالإضافة إلى أهها تعطى الموظفين انطباعاً لأداء مهامهم بعناية وبأقل ضرر للبيئة، مما يزيد من رفع الانتماء والولاء والثقة بين الموظفين، لذلك فإن المنظمات ذات السمعة الجيدة فى ادارة البيئة قد يكون لها مصدراً للميزة تنافسية لقدرتها على الاستقطاب موظفين عالي الأداء بينما كان الهدف من دراسـة Moraes, et al. هو تحليل المدى الذي تلعب فيها إدارة الموارد البشرية الخضراء المتمثلة في (التدريب البيئي للموظفين، والتمكين البيئي للموظفين، العمل الجماعي للأغراض البيئية، الأداء ذو الكفاءة البيئية) دورًا في تبني مبادئ الكفاءة البيئية في القطاع المالي. تم إجراء دراسة استقصائية شملت VN موظفًا يعملون في أحد أكبر البنوك المالية في البرازيل، توصلت هذه الدراسـة إلى النتائج التالية: من بين جميع العوامل التي تؤخذ في الاعتبار في هذه الدراسـة، التدريب البيئي فقط هو الذي يؤثر إيجابياً على الكفاءة البيئية مما ينتج عنه تحقيق الأهداف البيئية، والمساهمة في أداء بيئي أفضل للمنظمات والنضج البيئي ؛ وقد يكون التدريب يعاني من صعوبات بسبب العوائق المرتبطة بالتمكين والعمل الجماعي؛ وكذلك سيحصل برنامج الكفاءة البيئية للشركة المدروسة على فوائد إذا وفر المزيد من الاستقلالية للموظفين؛ وأخيراً، قد يكون برنامج الكفاءة البيئية للبنك المدروس أكثر فاعلية إذا كان متصلاً بفرق العمل الخضراء. ولقد جاء في دراسة Halawi, \& Zaraket, (2018) أن الشركات اللبنانية الخاصة يمكنها الحصول على ميزة تنافسية عند تبني إدارة موارد بشرية خضراء عالية المسئولية والمتمثلة في (التعويضات والمكافأت الخضراء، التحليل الوظيفي الأخضر، والتصميم الوظيفي الأخضر، الاستقطاب والاختيار الأخضر، التدريب الأخضر، تقييم الأداء الأخضر، ادارة الأداء الأخضر)، خاصة في ظل المنافسة الشديدة التي تميز العديد من الصناعات. يتم النظر إلى المسئولية الخضراء للشركات الخاصة اللبنانية في إطار 
الموارد البشرية من خلال أثرها على الاحتفاظ بالموظفين وخلق قضية نبيلة لهم. حاولت هذه الدراسة استكشاف موقف الشركات اللبنانية فيما يتعلق بمسؤولية الموارد البشرية الخضراء، والسعي إلى تقديم أفكار عامة مبسطة عن إدارة الموارد البشرية الخضراء بشأن سلوك عمل الموظف من خلال أخذ نموذج لشركتين لبنانيين يمثلان صناعات متنوعة، وكانت موجهة نحو مدراء الموارد البشرية. توصلت الدراسة إلى أنه لا يمكن أن يكون تشجيع الموظفين كبشرعلى الحفاظ على الممارسات الخضراء ناجحًا فقط إذا تم النظر في الجوانب البيئية في جميع الأعمال الأسـاسية. بالنسبة للقطاع المصرفي من ناحية أخرى، ووفقًا لنتائج وتحليل بطاقات الأداء المتوازن حيث زاد وزن البنك المدروس في المكون المالي، فإن البنك يزيد اهتمامه تدريجياً بالمخاوف المتعلقة بالممارسات الخضراء والجوانب البيئية. كما هدفت دراسة (2018) John,. \& Sathiq إلى التعرف على أثر ممارسات الموارد البشرية الخضراء المتمثلة في (الوصف الوظيفي الأخضر، التحليل الوظيفي الأخضر، الاستقطاب والاختيار الأخضر، التدريب الأخضر، ادارة الأداء الأخضر ، المكافأت الخضراء) على رضا الموظفين لدى بعض البنوك المجدولة أجريت هذه الدراسة في البنوك المختارة المجدولة مع حجم العينة المكون من IVr بنك بالهند. تُبين النتائج أن غالبية المبحوثين يفهمون مفهوم إدارة الموارد البشرية الخضراء ويقبلون ذلك كمفهوم قابل للتطبيق، وجدوا أن الممارسات الخضراء تؤثر على رضا الموظفين إيجابياً ، كما أن هناك فرق كبير في أثر ممارسات الموارد البشرية الخضراء بين أنواع مختلفة من البنوك ومستوى الرضا الوظيفي للموظفين وفق معايير معينة. تستنتج الدراسة أن غالبية البنوك مسئولة اجتماعياً وتقوم بمبادرات لتشجيع الممارسات الخضراء .بينما كان الهدف الرئيسي من دراسة (2017) .Sunita) مراجعة مستوى الممارسات الخضراء التي تتبناها البنوك الهندية المختلفة والمتمثلة في (الاستقطاب والاختيار الأخضر، المكافأت، التدريب البيئي، فرق العمل الخضراء، الثقافة البيئية الخضراء، مشاركة الموظفين الخضراء) ، وتجنيد استراتيجيات الموارد البشرية الفعالة لتبنها. من منظور الاستدامة البيئية، تشجع نتائج الدراسة على استخدام ممارسات الموارد البشرية الخضراء في القطاع المصرفي. وبشكل عام، لم يتم إدراج القضايا البيئية بالكامل في ممارسات إدارة الموارد البشرية التقليدية مثل الاختيار والاستقطاب والمكافآت والتخطيط الوظيفي من أجل الأداء البيئي الجيد. تم استنتاج وجود خلل بين ممارسات الموارد البشرية لدعم إدارة البيئة. ستساعد هذه الدراسـة أيضًا الإدارة العليا للقطاع المصرفي في وضع سياسات جديدة للموارد البشرية والصيرفة الخضراء من أجل بيئة مستدامة. ولقد هدفت دراسة Chanderjeet (2017) إلى ملاحظة أهمية مصطلح "التخضير" في وظيفة الموارد البشرية من خلال أحدث الحلول الصديقة للبيئة والتطويرالمتوقع لنموذج جديد لإدارة الموارد البشرية الخضراء. تزداد خدمات الصناعة المصرفية يوما بعد يوم على المستوى العالمي، لذلك يصبح من الضروري اكتشاف الممارسات الخضراء في الأعمال المصرفية وكذلك في البيئة. ركزت هذه الدراسـة على مختلف ممارسات إدارة الموارد البشرية الخضراء متبوعة بالقطاع المصرفي والمتمثلة في (الاستقطاب والاختيار الأخضر، المكافأت الخضراء، التدريب البيئي الأخضر، فرق العمل الخضراء، الثقافة البيئية الخضراء، مشاركة الموظفين الخضراء). ركزت الدراسـة بشكل أساسي على ممارسات إدارة الموارد البشرية الخضراء المختلفة والعلاقة بين المسئولية الاجتماعية المصرفية وإدارة الموارد البشرية الخضراء، وامتدت الدراسة إلى تقديم اقتراحات لإدارة الموارد البشرية حول مبادرات لجعل الصناعة المصرفية خضراء والاستفادة من تلك القيم نتج عن الجهود المبذولة فى مجال الموارد البشرية الخضراء زيادة في الكفاءات وتقليل فى التكاليف، والابقاء على الموظفين، وتحفيز الانتاجية، 
وفوائد ملموسة اخري. بالإضافة إلى أن الموارد البشرية هي لاعب اساسي في تطبيق ممارسات وسياسات ادارة الموارد البشرية

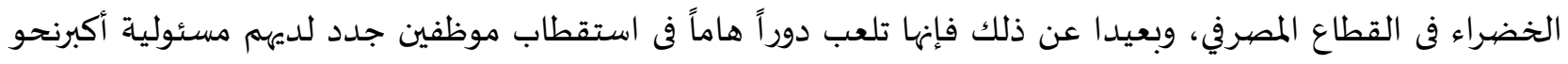

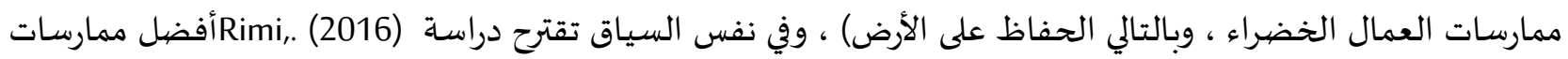
نموذج إدارة الموارد البشرية الخضراء المتمثلة في (الاستقطاب والاختيار الأخضر، التدربب الأخضر، تقييم الأداء الأخضر،التعويضات الأخضر) لتحسين وابتكار الخدمات المصرفية الخضراء للمؤسسات المصرفية في بنجلاديش. يقدم

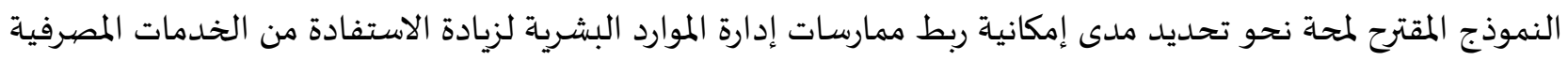

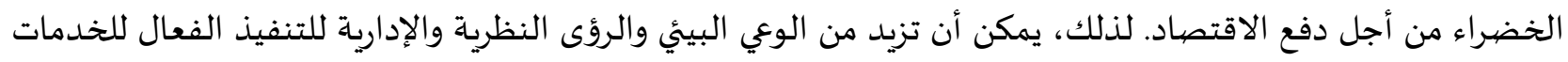

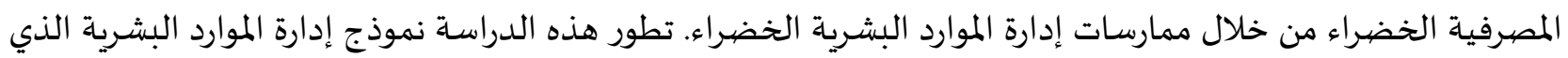
يشير إلى أن إدارة البنك يجب أن تربط ممارسات إدارة الموارد البشرية باستخدام قدرات موظفي البنك لتحسين وابتكار الخدمات المصرفية الخضراء في استراتيجياتهم الخضراء، كما يقدم استعراض الأدبيات الموجودة حول الأعمال المصرفية

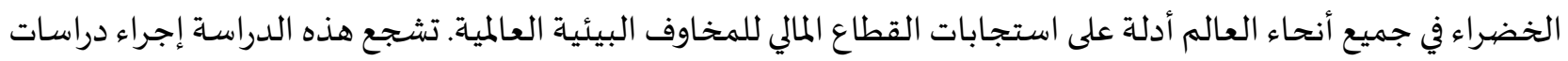

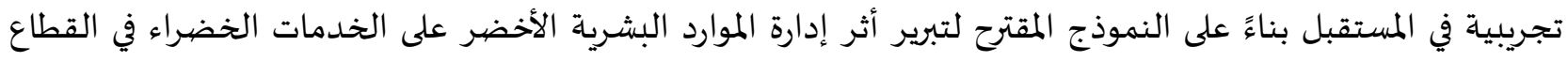
المصرفي والقطاعات الأخرى داخل وخارج بنجلاديش. وفي البيئة العربية توصلت دراسة (السكارنة، IV) إلى وجود أثر ذو دلالة إحصائية لممارسات إدارة الموار د البشرية الخضراء (التوظيف الأخضر، التدربب والتطوير الأخضر، تقييم الأداء الأخضر وحفظ الطاقة) علي استراتيجية التمايز بالمنظمات

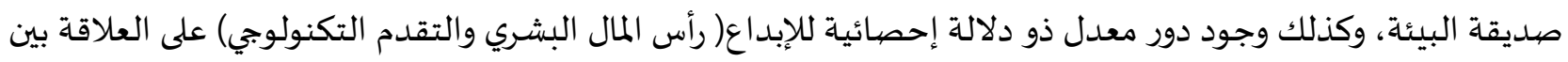

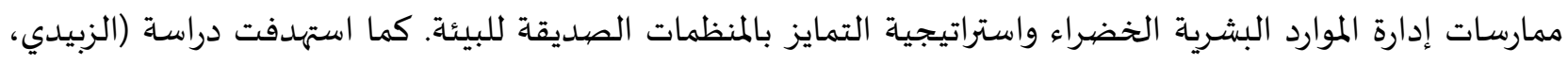

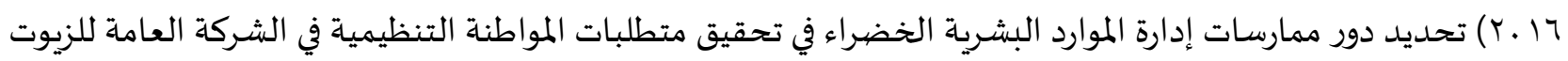
النباتية في العراق، وتم التركيز علي ممارسات إدارة الموارد البشرية الخضراء التالية ( التوظيف الأخضر، التدريب الأخضر،

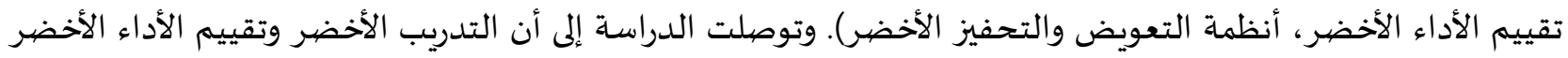
يؤثر على المواطنة البيئية، في حين لا يوجد أثر للتوظيف الأخضر وأنظمة التعويض والتحفيز الأخضر على المواطنة التنظيمية. كما هدفت دراسة (قطيشات، Y. Y. إلى بيان أثر الممارسات الخضراء لإدارة الموارد البشرية في الأداء الاجتماعي والبيئي في الشركة الأردنية لخدمات الزيوت والمحروقات، واعتمدت الدراسة علي المنهج الوصفي التحليلي. وبلغت عينة الدراسة (.با (I)

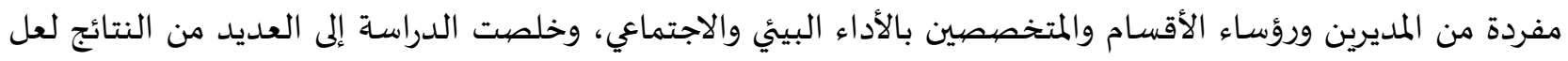
أهمها وجود أثر للممارسات الخضراء لإدارة المواردالبشرية (تحليل وتصميم الوظيفة الخضراء، والاستقطاب الأخضر،

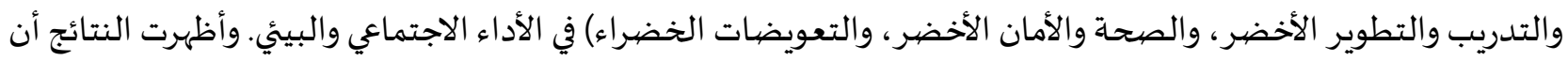
الصحاة والأمان الأخضر كان أكثر الممارسات الخضراء أثراً الخاء والي الأداء الاجتماعي والأداء البيئي. وعند مراجعة الأدبيات البحثية المتعلقة بالتنمية المستدامة يتضح قدرة نشاط الفكر الريادي للقرن العشرين في تعزيز النموالاقتصادي وتعزيزالأهداف البيئية وتحسين الظروف الاجتماعية في البلدان النامية بشكل عام لإحداث تنمية مستدامة 
شاملة، حيث هدفت دراسة (2019) Zimmermann, إلى التعرف على كيف تطبق البنوك الألمانية الاستدامة ؟ بالإضافة إنشاء تصنيف لاستراتيجيات الاستدامة التي تنفذها البنوك. تحقيقًا لهذه الغاية، أجريت بr مقابلة متعمقة داخل القطاع المصرفي الألماني للكشف عن أنماط الممارسات المستدامة لهذه المؤسسات المالية. على وجاه التحديد، هناك ثلاث ميزات رئيسية تميز هذه الاستراتيجيات. أولاً، تركز البنوك إما على أعمالها الأساسية أو الفرعية. ثانياً، يمكن للبنوك التركيز على القضايا الاجتماعية أو البيئية. ثالثًا، ضمن حدود أعمالها، يمكن للبنوك دعم مشروعات الاستدامة الخارجية من حيث التمويل أو المحتوى. وقد وجد أيضًا أن اختيار الاستراتيجية يكمن في مجموعة متباينة من دوافع الأعمال والدوافع الاجتماعية والبيئية. وبالتالي تستكشف الدراسة الطرق التي تسهم بها المؤسسات المالية في تحقيق أهداف التنمية المستدامة. يحسن التصنيف الموجود في هذا العمل الفهم فيما يتعلق بتنفيذ استراتيجيات الاستدامة ويشكل مصدر إلهام لمديري الاستدامة في البنوك، كما أنها يضيف إلى أبحاث الاستدامة في سياق الخدمات، والتي، على عكس الصناعة التحويلية، لم تخضيخ للبحث على نطاق واسع. وقد أجريت دراسة Kumar and Prakash (2019) على القطاع المصرفي الهندي لدراسـة مدى الإبلاغ عن الاستدامة من قبل البنوك العاملة في الهند. تم تحليل وترميز تقرير الاستدامة وتقرير المسئولية الاجتماعية للشركات وتقرير مسئولية الأعمال

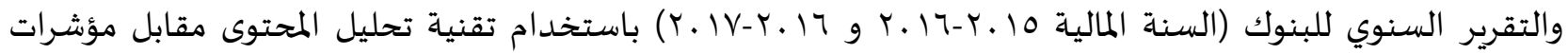
الاستدامة. هذه الدراسة هي واحدة من أولى الدراسات التي تدرس مدى الإبلاغ عن الاستدامة من قبل البنوك التجارية في الهند بما يتماشى مع المعايير والإرشادات الرئيسية المتعلقة بالاستدامة. تظهر نتيجة الدراسة أن البنوك في الهند أبطأ بكثير في تبني ممارسات الإبلاغ عن الاستدامة. لقد وجد أن قضايا الاستدامة ذات الأولوية العليا للبنوك ترتبط ارتباطًا مباشرًا بعملياتها التجارية مثل الدمج المالي والتثقيف المالي والتكنولوجيا الموفرة للطاقة، وغير ذلك. مؤشرات الاعتبارات البيئية لم يتم معالجتها نسبياً من قبل معظم البنوك في الهند. تظهر نتائج الدراسة أيضًا وجود اختلاف كبير في الكشف عن المؤشرات البيئية والبيئية الاجتماعية والبيئية بين بنوك القطاعين العام والخاص في الهند. بينما أشار(2019) Dikau,. \& Volz, إلى تكليفات البنك المركزي وأهداف الاستدامة وتشجيع التمويل الأخضر من خلال ورقة عمل تبحث هذه الورقة إلى أي مدى تتناسب المخاطر المرتبطة بالمناخ وسياسات التخفيف مع المجموعة الحالية من اختصاصات البنك المركزي وأهدافه. تحقيقًا لهذه الغاية، أجرى الباحث تحليلًا تفصيليًا لتكليفات وأهداف البنك المركزي باستخدام قاعدة بيانات التشريعات الخاصة بالبنك المركزي لصندوق النقد الدولي ومقارنتها بترتيبات ومسئوليات الاستدامة الحالية التي اعتمدتها البنوك المركزية في الممارسة العملية. تراجع الدراسة أيضًا المخاطر المحتملة والمفاضلات التي تنطوي عليها عندما تعمل البنوك المركزية كعوامل حفازة لتخضير النظام المالي. أظهر البحث التجريبي مدى ارتباط تفويضات البنك المركزي بالأنشطة الخضراء لدعم النمو المستدام أو دمج التمويل الأخضر أو دمج المخاطر المتعلقة بالمناخ في الأطر الأسساسية لتنفيذ السياسات. وتحلل دراسة (2019) . Korzeb أداء الاستدامة. تحليل مقارن في القطاع المصرفي البولندي من خلال مشاركة القطاع المصرفي البولندي في التنمية المستدامة من خلال تقييم متعدد الأبعاد. تبرز نتائج الدراسة العديد من أوجاء القصهور في أداء الاستدامة للأنشطة المصرفية التجارية. وجدت الدراسة انقساماً بين البنوك الوطنية والأجنبية. أظهرت البنوك المملوكة للحكومة والبنوك الوطنية التزامًا أكبر بهذه المسألة مقارنةً بالبنوك التي لديها رأس مال أجنبي. تشير النتائج إلى أن البنوك التي لديها رأس 
مال أجنبي لم تكن مهتمة بالكامل برعاية الأنشطة الرامية إلى التنمية المستدامة. تناقش دراسة (2018) . Volz كيفية تعزيز التمويل الأخضر للتنمية المستدامة في آسيا من خلال الحاجة إلى تخضير النظام المالي ودور الحوكمة المالية. يستعرض حالة الإقراض الأخضر والاستثمار في آسيا ويوفر نظرة عامة على مبادرات الإدارة المالية الخضراء في جميع أنحاء آسيا. تحدد الدراسة ابتكارات السوق لزيادة التمويل الأخضر في آسيا وكذلك الحواجز أمام الاستثمارات الخضراء والسياسة المالية وتسلط الضوء على المجالات ذات الأولوية لصانعي السياسات. وجدت الدراسة أيضًا أنه على الرغم من أن التمويل والاستثمار الأخضر لا يزالان في الوقت الحالي سوقًا متخصصية في النظم المالية الآسيوية، فقد كانت معدلات النمو مرتفعة ، وشهدت الأسـواق الآسيوية المختلفة بالفعل العديد من الابتكارات المالية الخضراء. وتدور دراسـة Igbudu, \& Popoola, (2018) حول تعزيز ولاء البنوك من خلال الممارسات المصرفية المستدامة من خلال فهم دور الممارسات المصرفية المستدامة في ولاء البنوك مع استكشاف الأثر الوسيط لصهورة الشركة على العلاقة بين الممارسات المصرفية المستدامة والولاء المصرفي. لهذه الدراسـة، تم اعتماد الاه استبيانات مستمدة من عملاء القطاع المصرفي. أظهرت النتائج من نمذجة المعادلة الهيكلية أن الممارسات المصرفية المستدامة أثرت بشكل إيجابي ومباشر على ولاء البنوك وصهورة الشركة، وصورة الشركة أثرت بشكل إيجابي ومباشر على ولاء البنوك، وصورة الشركة أيضًا توسطت في العلاقة بين الممارسات المصرفية المستدامة وولاء البنوك. وتقدم دراسة تطورات استكشافية في المعرفة حول دور البنوك في التنمية المستدامة للنظم الإيكولوجية الإقليمية. تسلط الدراسة الضوء على دور البنوك في تعزيز التنمية المستدامة للأراضي وفرصة الانتقال نحو رؤية بيئية مشتركة لتنمية الأراضي. يتم تحديد المتغيرات الرئيسية التي يمكن أن تدعم صناع القرار في هذا التطور بهدف التحقيق في دور البنوك في دعم ظهور منهج مشترك لتنمية الأراضي مستوحى من وجهة نظر النظم الإيكولوجية. تبرز الدراسة فرصة البنوك لتوسيع مهمتها بما في ذلك تعزيز التنمية الاجتماعية وحماية البيئة كعوامل رئيسية لتنمية الأراضي. بينما سلطت دراسة Romiguer, Alexandre, (2011) على أهمية استخدام معايير الاستدامة في طريقة عمل المنظمات، وكان أهم ما توصلت إليه من نتائج تركز المنظمات الإسبانية على تحسين صحة موظفيها في ظل توفير بيئات عمل آمنة وصحية.

والجديربالذكر أن البحث الحالي يختلف عن البحوث السابقة فى عدة جو انب لعل أهمها:

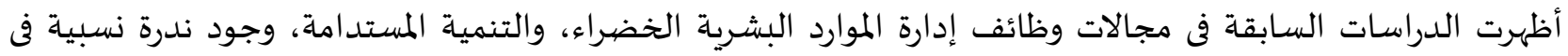

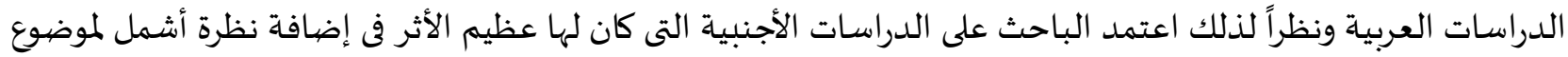
البحث، ويمكن إبراز ما يميز البحث الحالي عن البحوث والأدبيات السابقة بالنواحي التالية: نجد أن معظم الدراسات السابقة لم تركز على توضيح العلاقة بين الوظائف الخضراء لإدارة الموارد البشرية والتنمية

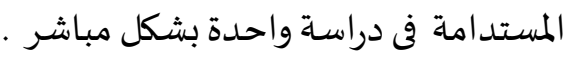

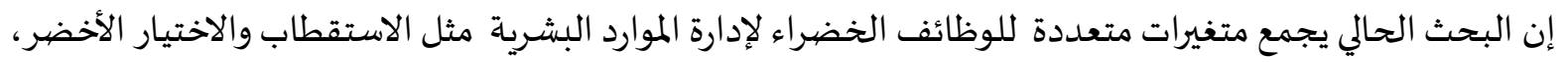
التدريب والتنمية الأخضر، إدارة الأداء الأخضر، التعويضات الخضراء، الوصف الوضيرة الوظيفي الأخضر، علاقات الموظفين الخضراء ، فرق العمل الأخضر، والثقافة الخضراء بهدف التعرف على أفضل الوظائف التى تتوافق مع البيئة المصرية، وهذا يعتبر مدخلاً وتحليلاً مغايراً لما تم في الدراسـات الأجنبية السابقة. 
إن معظم الدراسـات السابقة تناولت موضوع الوظائف الخضراء لإدارة الموارد البشرية من الاتجاه البيئي والحد من

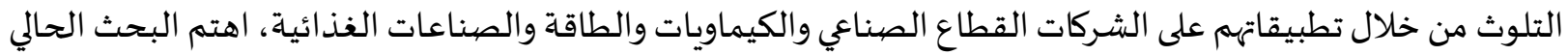

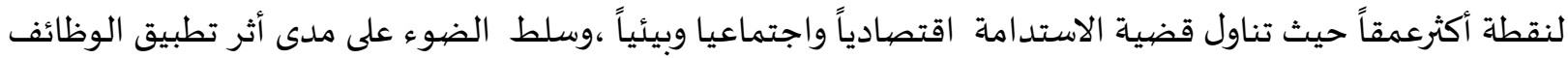

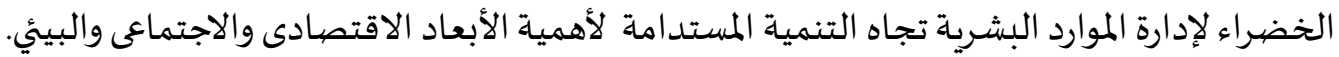
أشارت الدراسات التي تناولت موضوع الوظائف الخضراء للموارد البشرية إلى أن بعض النتائج المتعلقة بهذا المتغير تختلف من بلد لآخر، ومن قطاع إلى آخر، ومن بيئة وطبيعة عمل إلى آخري، لذلك جاء هذا البحث بمتغيرات فى بيئة مختلفة عن البيئات الي درست الوظائف الخضراء للموارد البشرية، والتى كان معظمها في بيئات صناعية وخدمياة متقدمة تختلف عن البيئة المصرية.

في ظل اتساع نطاق الأعمال العالمي الذى اختلف تماماً وظهور التحولات الرقمية والذكاء الاصطناعي، كل هذا التطور

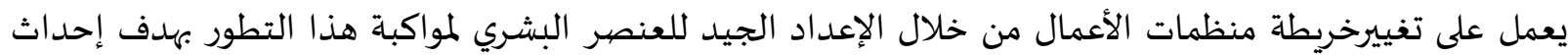

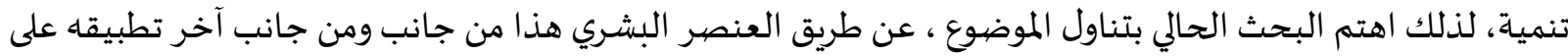
قطاع خدمات حيوي فى اقتصاد الدول، وخدمة المجتمع، والحفاظ على سلامة البيئة، فتم التطبيق على القطاع المصرفي والمتمثل فى بنك القاهرة بمحافظة الاسكندرية فيعتبر ذلك شكل مختلف عن ما تناولته الدراسات السابقة لمجالات التطبيق المتمثل فى الشركات الصناعية والحد من التلوث البيئي.

ب- مشكلة البحث

تم إدخال الوعي البيئي في أنظمة الإدارة كوسيلة لإدارة البيئة من خلال أنشطة المنظمة. وفي هذا الصددد، يضع المديرون أنظمة

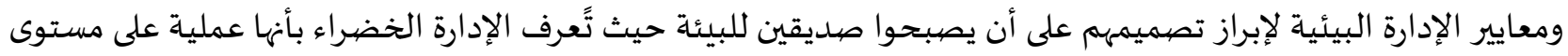

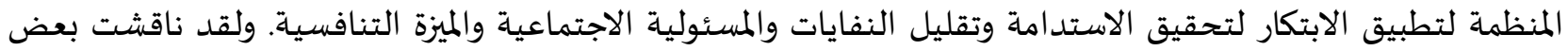
الدراسات كيف يمكن لتطبيق الإدارة الخضراء في المنظمات أن تضمن الترتيب المستمر للأنشطة وتقييمها من منظور بيئي إلى الحد من التلوث ومنع حدوثه. مثل (2019) .Jaid, \& Misal والتى كان الغرض منها هو التحقق من العلاقة بين الوظائف الخضراء بأبعادها المتمثلة في (التصميم الوصفي الأخضر، الاستقطاب والاختيار الأخضر، ادارة الاداء الأخضر، المكافأت والتعويضات الخضراء، ومشاركة الموظفين الخضراء) والأداء التنظيمي من قبل موظفي بنك ICICI بالهند. والتى توصلت إلى إلى وجود أثر إيجابي قوي بشكل جزئي فيما يتعلق بالوظائف التعويض والمكافآت ادارة الاداء الأخضر ومشاركة الموظفين ورفضيه

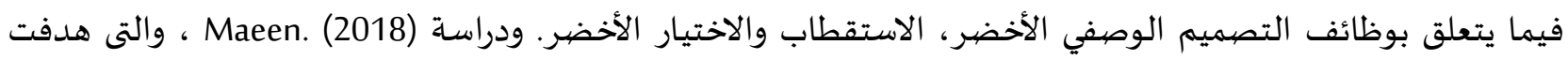

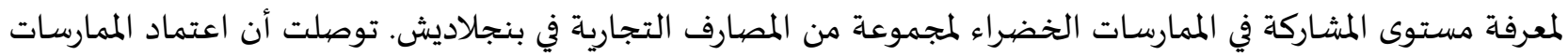

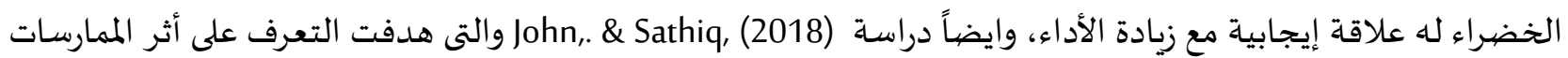

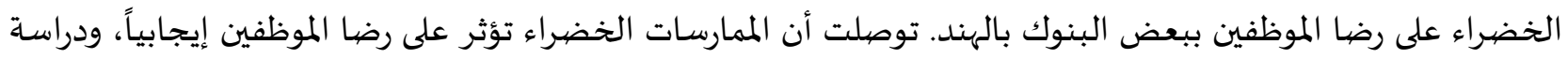

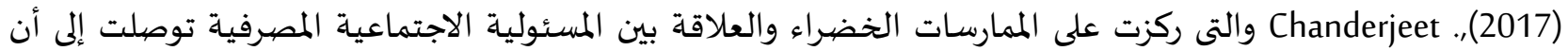
الموارد البشرية هي لاعب محوري في تطبيق السياسات الخضراء في القطاع المصرفي، وتلعب دوراً إيجابياً في استقطاب موظفين جدد لديهم مسئولية أكبر نحو ممارسات العمال الخضراء. وأن دراسة (2016) . Rimi, والتى اقترحت نموذج لأفضل مولى ممارسات إدارة الموارد البشرية الخضراء لتحسين الخدمات المصرفية الخضراء وجدات أنداء الوظائف الخضراء لهاء لهاء علاقة إيجابيةمع الوعي البيئي للتنفيذ الفعال للخدمات المصرفية الخضراء. 
على ضيوء ماسبق يلاحظ أن معظم الدراسات تناولت الوظائف الخضراء لإدارة الموارد البشرية إلا أنها لم تربطها بمدي علاقتها بشكل مباشر بالتنمية المستدامة، لذلك يتناول الباحث في هذا البحث أثر الوظائف الخضراء لإدارة الموارد البشرية وربطها بشكل مباشر في تحقيق التنمية المستدامة في فروع بنك القاهرة بمحافظة الاسكندرية. ومن خلال الفهم الأكثر عمقاً للوظائف الخضرا، وتطبيقها بشكل علمي ومنهبي سليم، يمكن للمنظمات تحسين آدائها الاقتصادى والاجتماعى والبيئي بطريقة

تتسم بالإستمرارية ، حيث تعتبر الوظائف الخضراء لإدارة الموارد البشرية من الأدوات القوية التى تجعل من المنظمات خضراء.

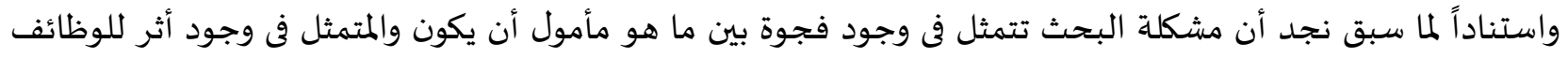

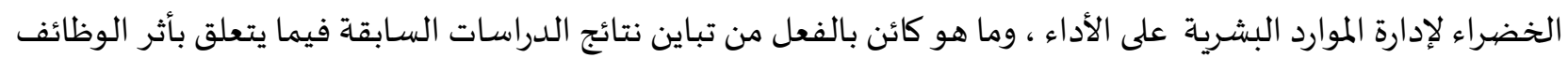

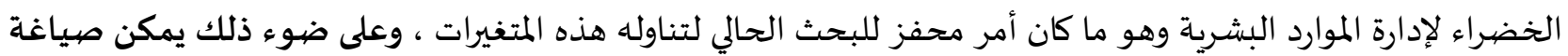
مشكلة البحث في التساؤل الرئيسي التالي: - هل تؤثر الوظائف الخضراء لإدارة الموارد البشرية على التنمية المستدامة بفروع بنك القاهرة بمحافظة الاسكندرية ؟ وكيف يسهم بنك القاهرة بمحافظة الاسكندرية بممارساته الخضراء في التنمية المستدامة ( اقتصادياً / اجتماعياً وبيئياً) ؟. ع- أهداف البحث إن الهدف الرئيس للبحث يكمن فى دراسة وتحليل أثر الوظائف الخضراء لإدارة الموارد البشرية على التنمية المستدامة ببنك

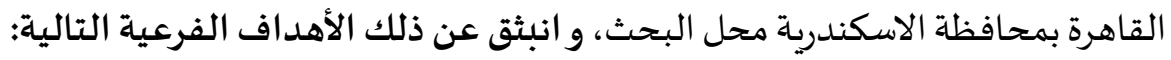
ا- معرفة مدي وجود أثر لوظائف ادارة الموارد البشرية الخضراء- الاستقطاب والاختيار الأخضر، التدريب والتنمية

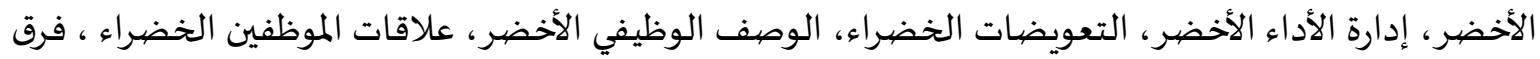

العمل الأخضر، والثقافة الخضراء على البُعد الاقتصادي للتنمية المستدامة ببنك القاهرة بمحافظة الاسكندرية

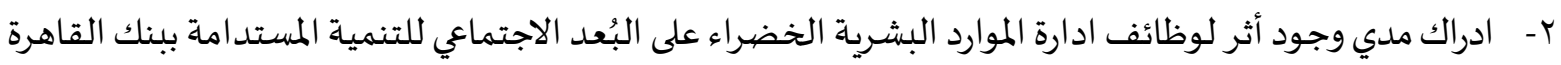

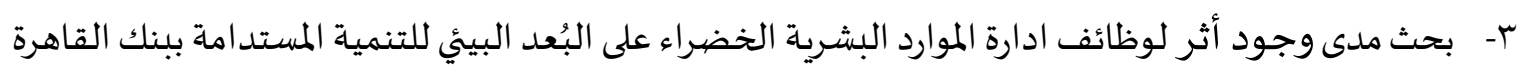
ع- اختبار النموذج المقترح لأثر الوظائف الخضراء لإدارة الموارد البشرية على التنمية المستدامة ببنك القاهرة محل البحث. 0- أهمية البحث

تتمثل أهمية هذا البحث من أهمية الأهداف التى يسعى الباحث لتحقيقها، ويعتبر هذا البحث محاولة للتعرف على أثر الوظائف الخضراء لإدارة الموارد البشرية على التنمية المستدامة على فروع بنك القاهرة بمحافظة الاسكندرية. • الأهمية العلمية للبحث:

هناك ندرة نسبية في معالجة هذا الموضوع على مستوى المنظمات العربية، وبالتالي يمكن اعتبار هذا البحث من الأبحاث التى يمكن الاستفادة منها مستقبلاً. الأهمية التطبيقية للبحث:

- - الكشف عن أثر الوظائف الخضراء لإدارة الموارد البشرية على التنمية المستدامة على فروع بنك القاهرة بالاسكندرية - اعتبار هذا البحث امتداداً للدراسات التي تهتم بالوظائف الخضراء لإدارة الموارد البشرية والأداء فى منظمات الأعمال. - يساهم هذا البحث في التطرق للوظائف الخضراء لإدارة الموارد البشرية وهو ما قد يمثل إضافة إلى الجانب النظري، وتوجيه النظر لإدارة الموارد البشرية الخضراء، انطلاقاً من دورها الإيجابي القوي حال تطبيقها. - تحسين اداء القطاع المصرفي لماله من أهمية بالغة في المساعدة على تحسين الاقتصاد المصرى 
- قد تكون توصيات هذا البحث مفيدة للمديرين عند اتخاذ القرارات المتعلقة بتوسيع أعمالهم ، واتخاذ خطوات لجعل الأنظمة البيئية أكثر قدرة من حيث الأستدامة البيئية. كما أن نتائج هذا البحث قد تكون هامة مستقبلاً لإضافة مجموعة المعارف من خلال توسيع أبحاث الوظائف الخضراء في قطاع الخدمات. 7- منهبج البحث

\section{تستخدم المناهج والأسساليب التالية لتحقيق هدف البحث:}

- المنهج الاستنباطي: لإيجاد الخلفية النظرية التي تستند إليها التساؤلات البحثية فيما يتعلق بمتغيرات البحث،

$$
\text { واشتقاق فروض البحث وإعداد الإطار النظري. }
$$

- المنهج الاستقر ائي: في اختبار فروض البحث عن طريق الاستقصاء عن مدي وجود أثر للوظائف الخضراء لإدارة

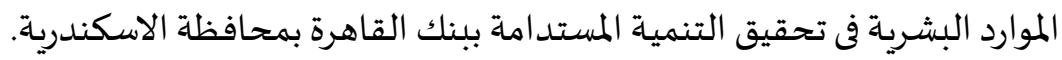

\section{- V - النموذج المقترح للبحث}

بناءاً على مراجعة الأدبيات البحثية التى تناولت الوظائف الخضراء لإدارة الموارد البشرية وتبين منها أن هذه الوظائف يمكن

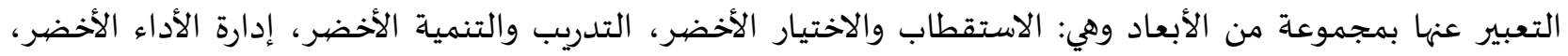

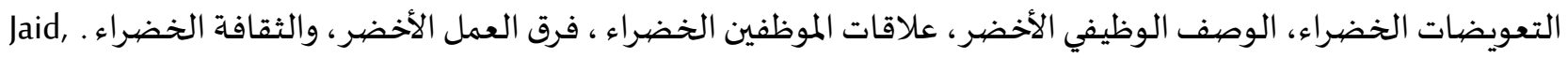
Chanderjeet \& Sunita. 2017 \& John, \& Sathiq, 2018 \& Halawi, \& Zaraket, 2018 \& Maeen. 2018 \& \& Misal, 2019

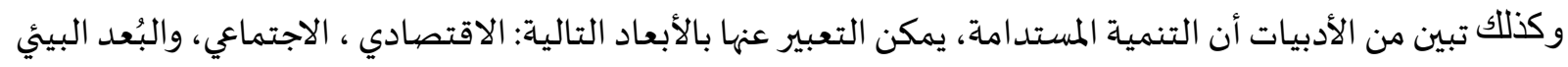
Zimmermann, (2019) \& Kumar and Prakash (2019) \& Dikau, \& Volz, (2019) \& Korzeb, (2019) \& Volz, (2018) \& Igbudu, \& Popoola, (2018) \& Vincenzo, \& Fransesco. (2017) \& Romiguer, Alexandre, (2011).

وتأسيساً لما سبق يتكون النموذج المقترح للبحث من أحدي عشر متغير، والشكل رقم (1) يوضح النموذج المقترح للبحث:

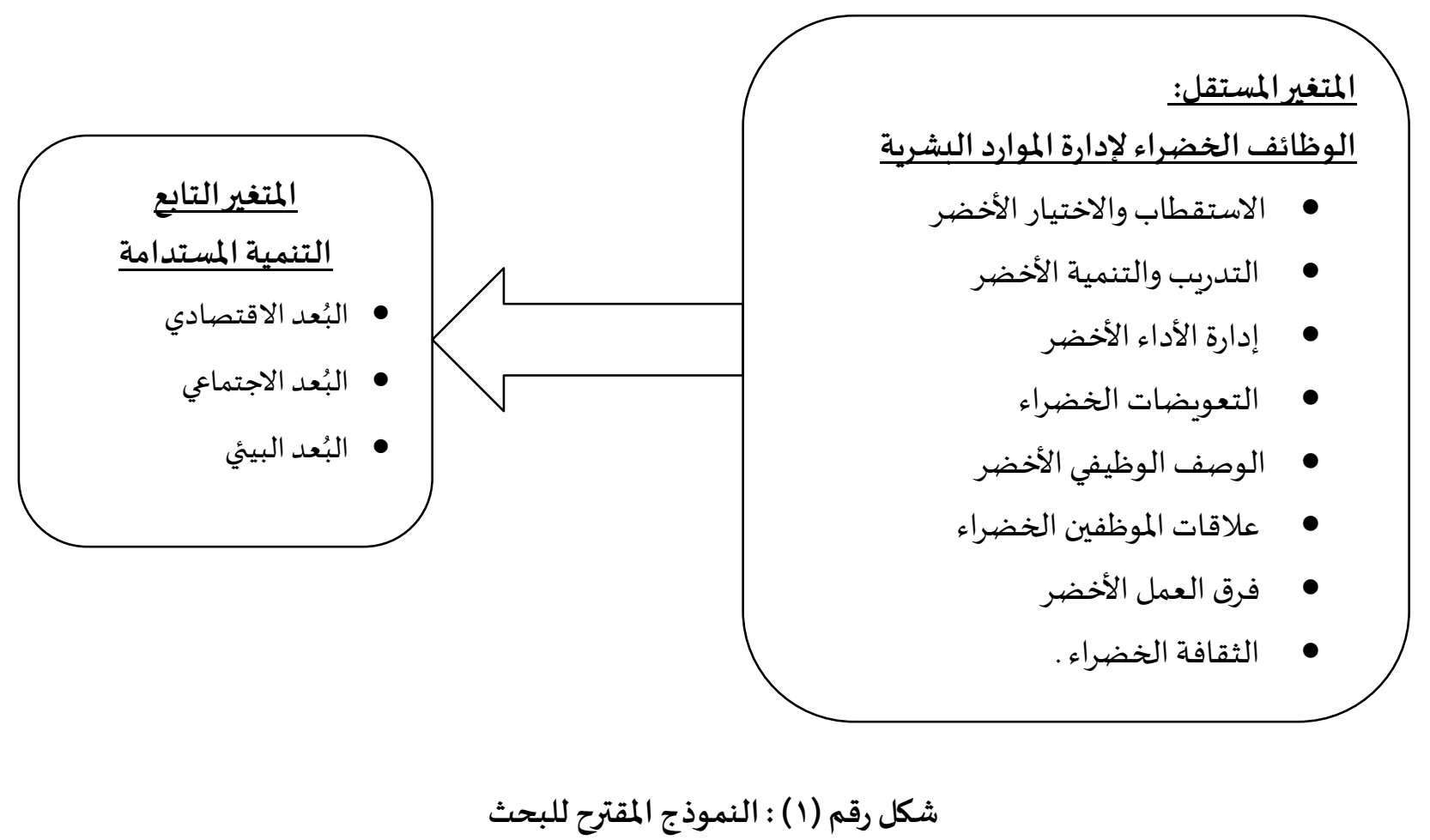


بناءاً على النموذج المقترح للبحث يمكن تصنيف متغيرات البحث إلى نوعين من المتغيرات هما:

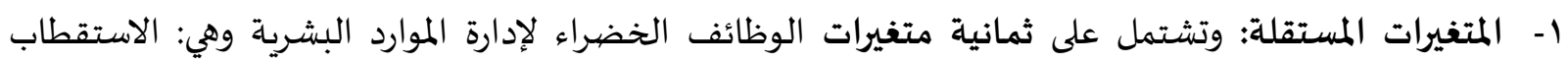
والاختيار الأخضر، التدربب والتنمية الأخضر، إدارة الأداء الأخضر، التعويضات الخضراء، الوصف الوظيفي

الأخضر، علاقات الموظفين الخضراء ، فرق العمل الأخضر، الثقافة الخضراء.

r- المتغيرات التابعة: وتشتمل على ثلاثة متغيرات تمثل التنمية المستدامة وهي: البُعد الاقتصادي، الاجتماعي ، والبيئي

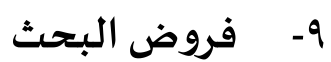
بناءاً على تلك العلاقات المفترضة في النموذج المقترح للبحث والتي تم استخلاصها استناداً إلى نتائج الأدبيات البحثية، وإنطلاقاً من مشكلة البحث وأهدافه، يمكن صياغة مجموعة من الفروض التي يمكن اختبارها للإجابة على تساؤلات البحث وتحقيق أهدافه، وهي كالتالي:-

الفرض الأول (Hoا ) تؤثر الوظائف الخضراء لإدارة الموارد البشرية أثراً إيجابياً معنوياً على التنمية المستدامة. وأمكن للباحث تقسيم هذا الفرض إلى الفروض الفرعية التالية:

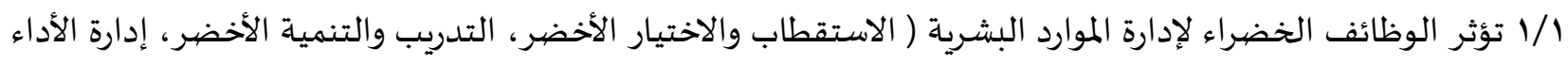

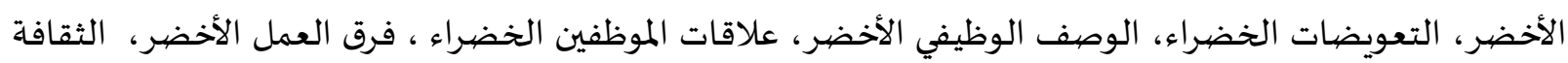

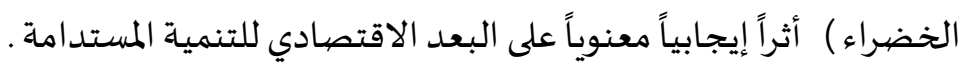

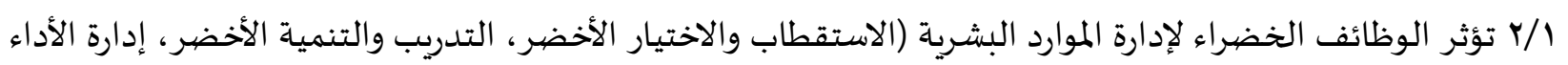

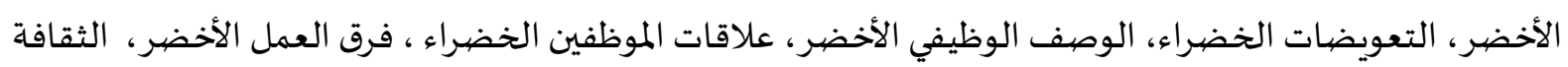

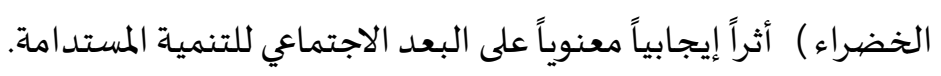

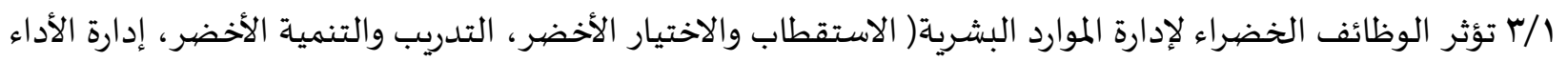

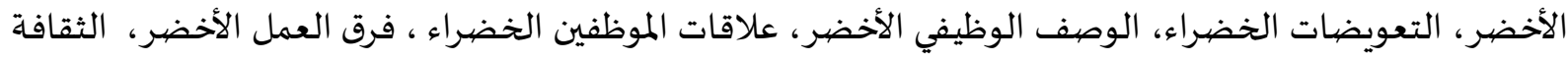

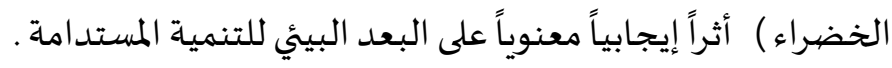

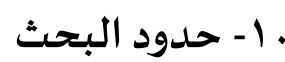

$$
\begin{aligned}
& \text { يمكن تقسيم حدود هذا البحث إلى :- }
\end{aligned}
$$

ـ ـ ا الحدود الزمنية: تتمثلت فى الفترة التى تم تجميع البيانات الأولية اللازمة للبحث من مصادرها المختلفة، وهى الشهور

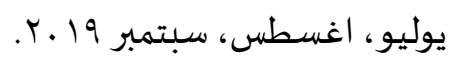

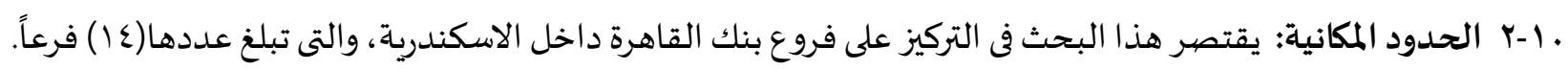

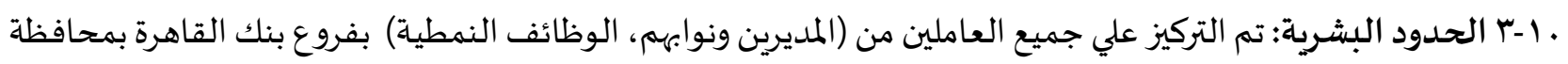

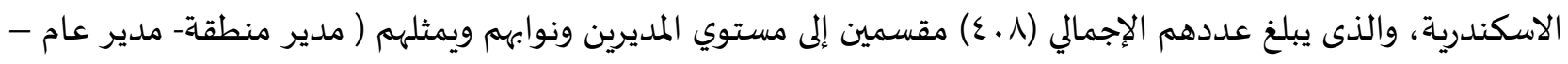

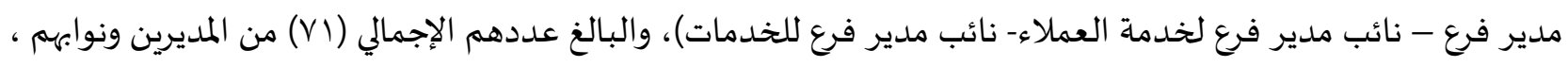

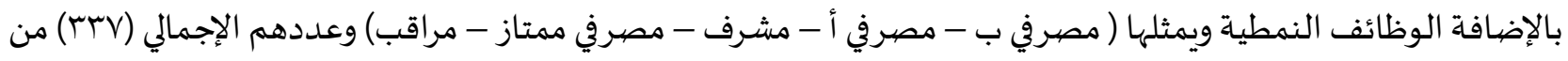
تلك الوظائف. 
يتناول هذا الجزء المنهجية التى اعتمد عليها البحث لتحقيق أهدافه، وذلك بتحديد مقاييس متغيرات البحث، الطريقة الإحصائية المستخدماة، مجتمع وعينة البحث وجمع البيانات، تحليل البيانات والنتائج.

|1 - امقايلس متغيرات البحث

قام الباحث بقياس المتغير المستقل محل البحث والمتمثل في الوظائف الخضراء لإدارة الموارد البشرية من خلال ثمانية أبعاد فرعية هي: الاستقطاب والاختيار الأخضر، التدريب والتنمية الأخضر، إدارة الأداء الأخضر، التعويضات الخضراء، الوصف الوظيفي الأخضر، علاقات الموظفين الخضراء ، فرق العمل الأخضر، والثقافة الخضراء، بحيث تم قياس كلٍ منها باستخدام نموذج قياس عاكس وهو يعني أن عند تطوير البنية البحثية، يجب علي الباحثين التفكير في نوعين واسعين من مواصفات القياس هما: نموذجي القياس العاكس والنموذج التكويني/ البنائي. نموذج المقياس العاكس يستند مباشرة إلي نظرية الاختبار الكلاسيكية ـ ووفقاً لهذه النظرية ، تمثل المقاييس تأثيرات (أو مظاهر) للبنية الأساسية ، لذلك تأتي العلاقة السببية من البناء وصولاً إلي مقاييسا،، يمكن الاطلاع علي المؤشرات العاكساه كعينة تمثيلية لجميع العناصر المحتملة المتاحة في المجال المفاهيمي للبناء لذلك، وبما أن المقياس العاكسي يفرض أن جميع عناصر المؤشر ناتجـة عن نفس البنية ( أى أنها تنبع من نفس المجال) ، يجب أن ترتبط المؤشرات المرتبطة ببنية معينة ارتباطاً وثيقاً مع بعضها البعض. بالإضافة إلى ذلك، يجب أن تكون العناصرالفردية قابلة للتبادل ، ويمكن عموماً تجاهل أى عنصر واحد دون تغيير معني البناء ، طالما أن البناء لديه الثبات الكافي. حقيقة أن العلاقة تنتقل من البنية إلى مقاييسها تعني أنها إذا تغير تقييم الصفة الكامنة ( علي سبيل المثال، بسبب Mashala, (2018) \& Sunita, (2017) التغيير في معيار المقارنة)، فإن جميع المؤشرات ستتغير في وقت واحد. استناداً إلى \&Moraes, et al, (2018) \& Tang, et al, (2017) الموظفين الخضراء باستخدام نموذجي قياس يتضمن كل منهما ست فقرات، بينما تم قياس التدريب والتنمية الأخضر، إدارة الأداء الأخضر، التعويضات الخضراء ، فرق العمل الأخضر، والثقافة الخضراء باستخدام نماذج قياس يتضمن كل منها خمس فقرات. وأخيراً، تم قياس الوصف الوظيفي الأخضر باستخدام نموذج قياس يتضمن ثلاث فقرات. كما قام الباحث بقياس المتغير التابع محل البحث والمتمثل في التنمية المستدامة من خلال ثلاثة أبعاد فرعية هي: البُعد Bunting et (الاقتصادي، البُعد الاجتماعي، والبُعد البيئي، بحيث تم قياس كلٍ منها باستخدام نموذج قياس عاكس استناداً إلى 2015) .al. وبشكل أكثر تحديداً، تم قياس البُعد الاقتصادى للتنمية المستدامة باستخدام نموذج قياس يتضهمن ثلاث فقرات، في حين تم قياس البُعد الاجتماعي للتنمية المستدامة باستخدام نموذج قياس يتضمن خمس فقرات، وأخيراً، تم قياس البُعد البيئي للتنمية المستدامة باستخدام نموذج قياس يتضمن فقرتان، ولقد قام المستقصى منهم بتحديد مدي اتفاقهم أو اختلافهم مع العبارات الممثلة لبنود نماذج القياس وذلك على مقياس ترتيبي ذو مسافات متساوية (مقياس ليكرت الخماسي ذو

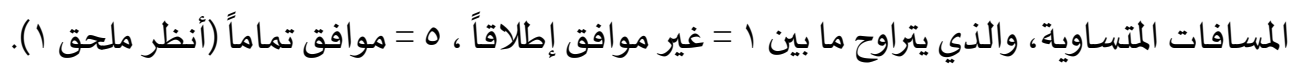


أولاً: لغرض تقييم ثبات ، وصدل نماذج القياس قام الباحث باستخدام الأتي: معامل التحميل: يستخدم لقياس صددق التقارب لمقياس المتغير . مؤشر الثبات المركب: يستخدم لقياس الثبات الاتساق الداخلي . متوسط التباين المستخلص: يستخدم لقياس صدةق التقارب لنماذج القياس معيار"فورنيل-لاركر" : وهذا المعيار يقوم بتقييم صدق التمايز Discriminant Validity ثانياً: نتائج الإحصياء الوصفي للتعرف علي نتائج الإحصاء الوصفي ممثلاً في: الوسط الحسابي - الانحراف المعياري لجميع متغيرات البحث، فضلاً عن معاملات الارتباط فيما بين تلك المتغيرات. ثالثا: اختبارات الفروض: لغرض قياس فروض البحث استخدم الباحث تقييم النموذج البنائي من خلال: قام الباحث باستخدام طريقة المربعات الصغرى الجزئية لنمذجة المعادلة البنائية، وذلك بالاستعانة ببرنامج التحليل الإحصائي Ringle et al., (2005) SmartPLS 2.0 هي طريقة قائمة على التباين لتقدير نماذج المعادلة البنائية وذلك بهدف تعظيم التباين المفسر للمتغيرات الكامنة أو غير المشاهدة داخلية المنشأ، وبعبارة أخري، يمكن القول بأن تلك الطريقة تقوم بتقدير المعاملات (علاقات نموذج المسار) بالشكل الذي يؤدي إلى تعظيم قيم معامل التحديد (R2) للمتغيرات التابعة (Hair et al.,(2014b. بالإضافة إلى إهها تعمل بكفاءة مع العينات صغيرة الحجم والنماذج المعقدة، فضلاً عن أهها عملياً لا تضع أية قيود أو افتراضات حول البيانات المستخدمة (خاصة فيما يتعلق بنمط توزيع البيانات). بالإضيافة إلى سهولة تعاملها مع نماذج القياس العاكسة والتكوينية على حد سواء فضلاً عن المتغيرات التي يتم قياسها بفقرة وحيدة وذلك دونما أية مشاكل، وبالتالي إمكانية تطبيق تلك الطريقة على نطاق واسع من المواقف البحثية. وأخيراً، توفر تلك الطريقة درجة عالية من الكفاءة في تقدير المعلمات والتي تتجلى في القوة الإحصائية التي تفوق تلك الناجمة عن طريقة

Hair et al., نمذجة المعادلة البنائية القائمة على التغاير (2011) (11

يتمثل المجتمع المستهدف للبحث الحالي في جميع المديرين والموظفين بفروع بنك القاهرة بمحافظة الاسكندرية والبالغ عددهم 1.ـ مفردة. (أنظر ملحق ץ).لتوضيح بيان بهذا العدد موزع على الفروع (مديرين ووظائف نمطية) ولغرض جمع البيانات Krejcie, \& الأولية اللازمة لإتمام البحث، قام الباحث باختيار عينة بلغت 197 مفردة وفقا لتحديد حجم المجتمع وفقاً

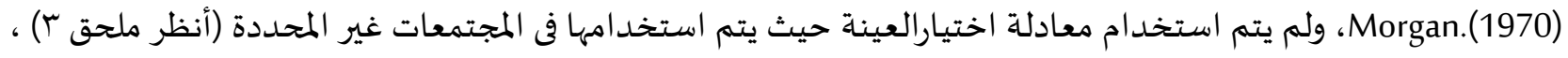
ولقد تم الإتصال بالمشاركين المحتملين عن طريق المقابلة الشخصياة، وذلك دون اتفاق مسبق مع أي منهم، فضلاً عن التأكيد على أن البيانات المجمعة لن يتم استخدامها إلا لأغراض بحثية. ولقد بلغ إجمالي عدد المشاركين في البحث 9 1/ مفردة من أصل 197 بمعدل استجابة بلغ ع,97\%، ولقد قام الباحث باستبعاد سبع قوائم استقصاء بسبب تجاوز حجم البيانات المفقودة في 
تلك القوائم نسبة الـ 10 من إجمالي عدد عبارات الاستبيان والتي تبلغ .0 عبارة. تنقية البيانات من أنماط الاستجابة المريبة أو المشكوك فها، والتي تمثل قيام المستقصى منهم بالرد بنفس الإجابة على نسبة عالية من أسئلة قائمة الاستقصاء أدت إلى

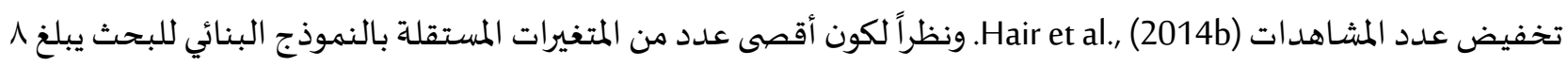
متغيرات، والحد الأدنى لمتطلبات حجم العينة اللازم لتحقيق قوة إحصائية تبلغ .ی\%، وقيم معاملات تحديد R2 لا تقل عن • 1\% بإحتمال خطأ 0\% هو عVا مشاهدة. لذلك فإن عدد المشاهدات والبالغ 1/1 مفردة يعتبر كافي لتقدير نموذج المسار.

Cohen, للبحث الحالي باستخدام طريقة المربعات الصغرى الجزئية (1992)

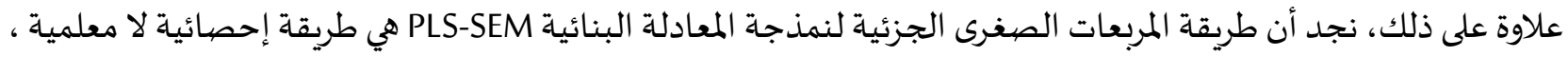

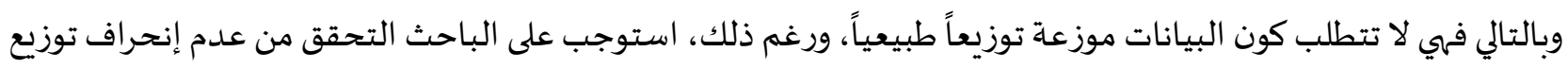
البيانات بشكل كبير عن التوزيع الطبيعى، حيث أن عدم إعتدال التوزيع بشكلٍ حاد يخلق إشكالية في تقييم معنوية معلمات النموذج (Henseler et al.., لذا، لما، تم قياس مدى إلتواء Skewness وتفرطح Kurtosis توزيع مؤشرات متغيرات البحث باستخدام الإصدار رقم بم من برنامج الحزمة الإحصائية للعلوم الاجتماعية (SPSS)، وتبين انحراف توزيع بعض المؤشرات

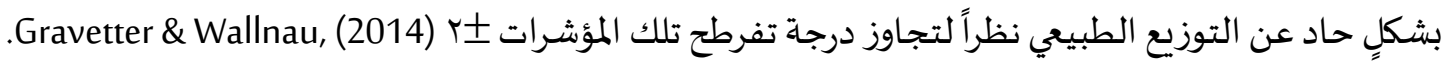
لذلك قرر الباحث إسقاط مؤشر واحد (الفقرة رقم آ بقائمة الاستقصاء) من نموذج قياس متغير التعويضات الخضراء (معامل تفرطح = Y,YON)، ومؤشر واحد (الفقرة رقم \イ بقائمة الاستقصاء) من نموذج قياس متغير علاقات الموظفين

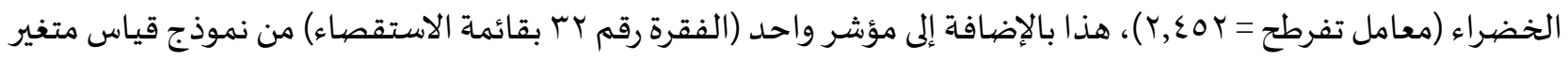

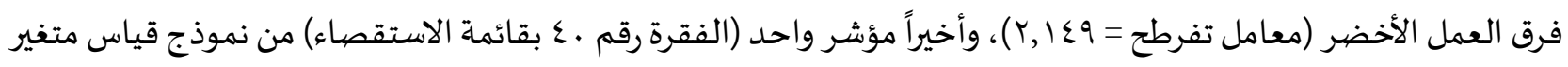

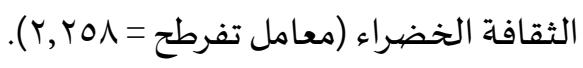
الخصائص الديموجرافية للمشاركين بالبحث يمكن استعراضها فيما يلي: غالبية المديرين والموظفين بفروع بنك القاهرة بمحافظة الاسكندرية والمشاركين بالبحث الحالي من الذكور (7,. Y\%)، جميع فئات المستوى الوظيفي ممثلة بشكلٍ جيد،

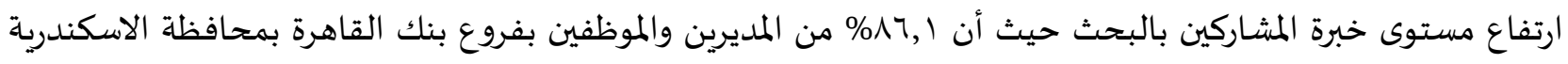

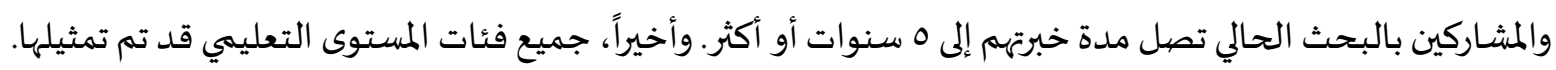

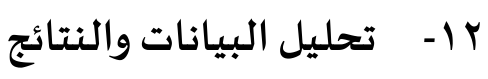
ب ا ا ا نتائج الإحصاء الوصفي يوضح جدول رقم (r) نتائج الإحصاء الوصفي ممثلاً في قيم الوسط الحسابي والانحراف المعياري لجميع المتغيرات محل البحث، فضلاً عن معاملات الارتباط فيما بين تلك المتغيرات. يمكن ملاحظة أن قيم الوسط الحسابي للأبعاد الممثلة للوظائف

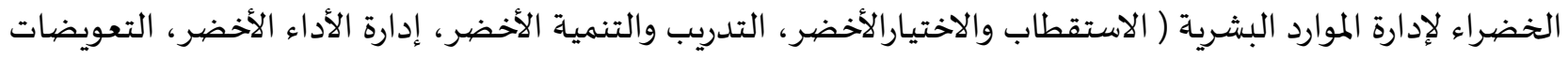

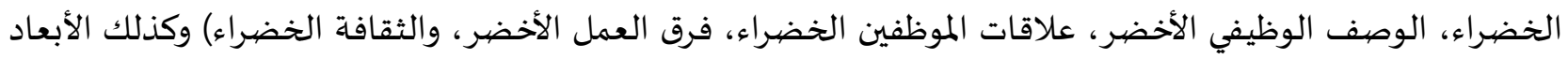

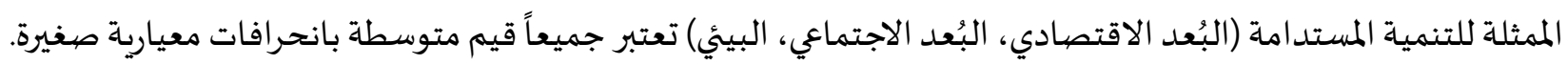


جدول رقم (r)

الإحصاء الوصفي ومصفوفة معاملات الارتباط بين متغيرات البحث

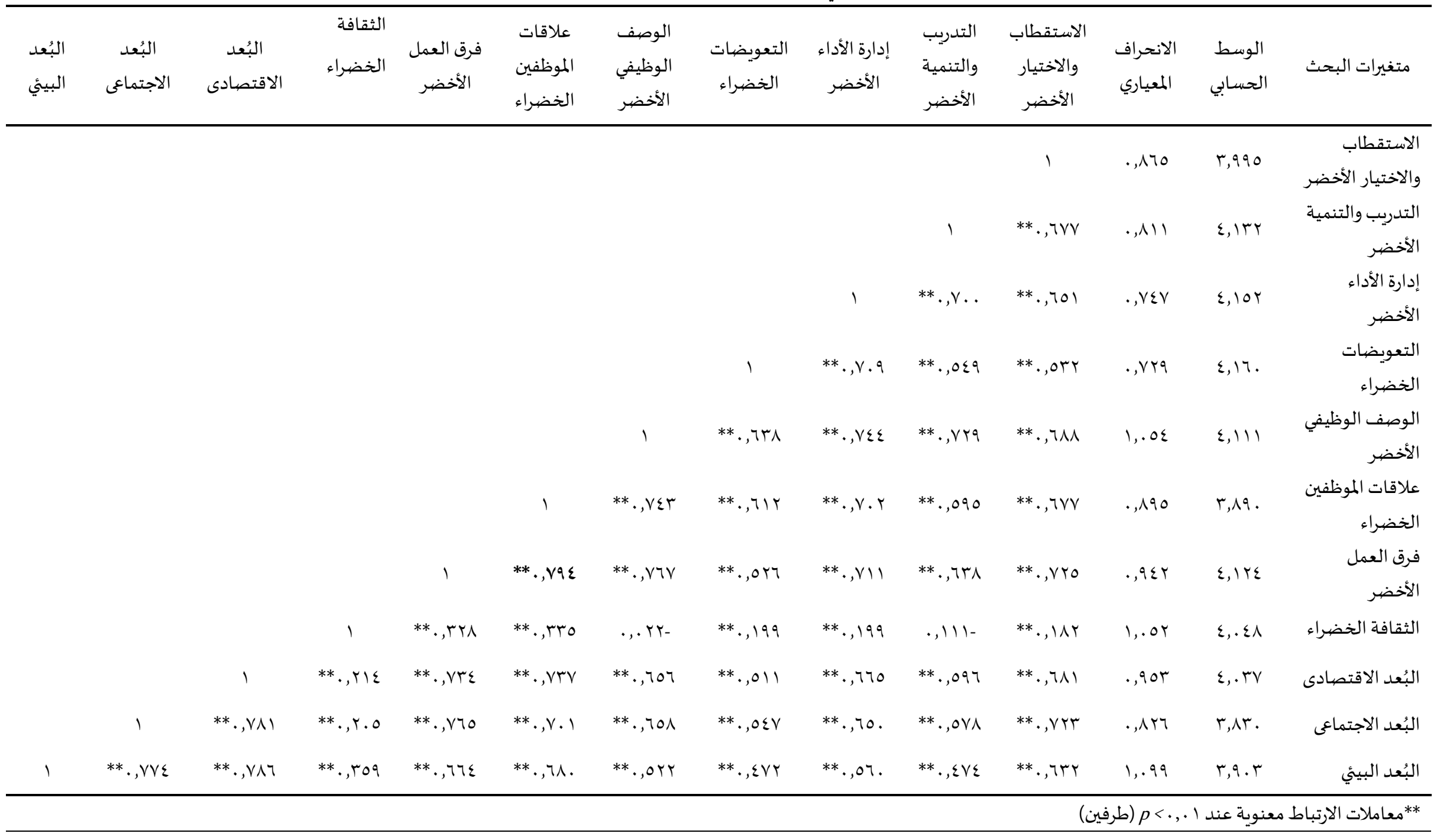


علاوة على ذلك، وبناءاً على معاملات الارتباط الموضحة بجدول رقم (؟)، رصد الباحث وجود علاقات ارتباط طردية قوية

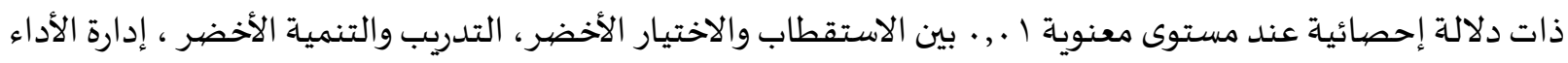
الأخضر، التعويضات الخضراء، الوصف الوظيفي الأخضر، علاقات الموظفين الخضراء ، فرق العمل الأخضر من ناحية،

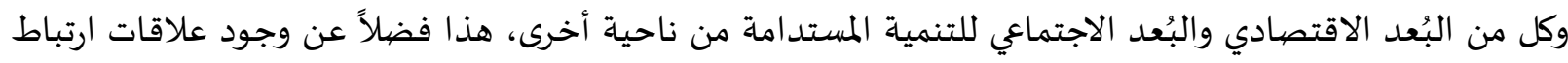

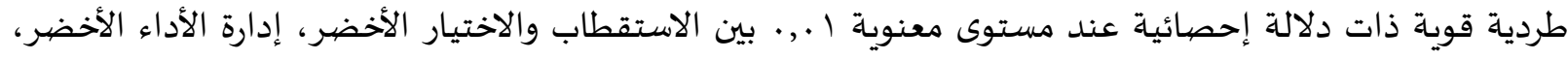

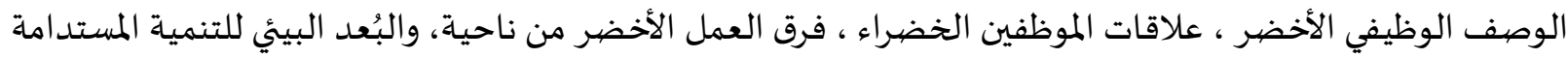

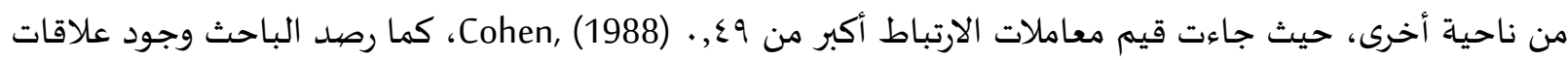
ارتباط طردية متوسطة القوة ذات دلالة إحصائية عند مستوى معنوية ا . . . بين التدريب والتنمية الأخضر ، التعويضيات

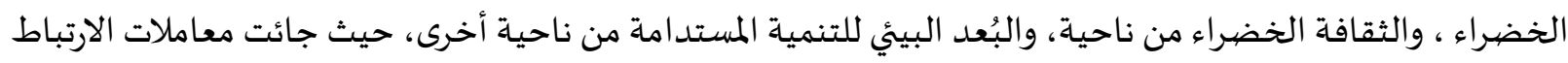

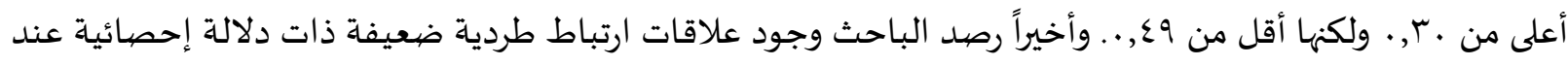

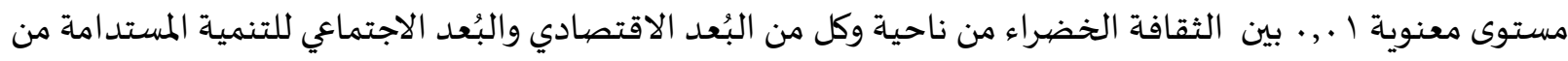
ناحية أخرى حيث جاءت قيم معاملي الارتباط أقل من • ؟َ, .. النتائج السابقة تعد مؤشراً للأثر الإيجابي للوظائف الاستقطاب والاختياتيار الأخضر ، التدريب والتنمية الأخضر ، إدارة

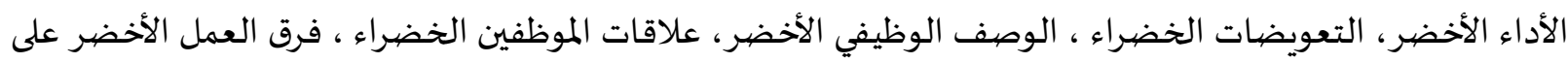

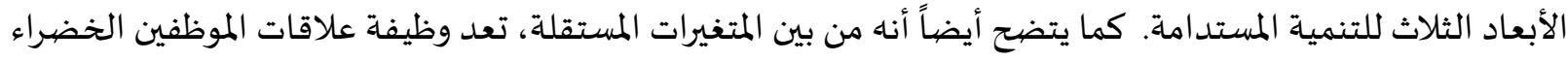

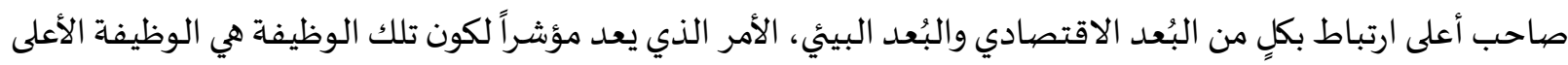

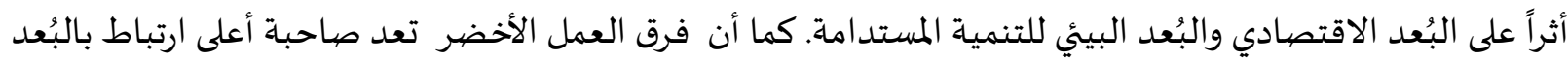

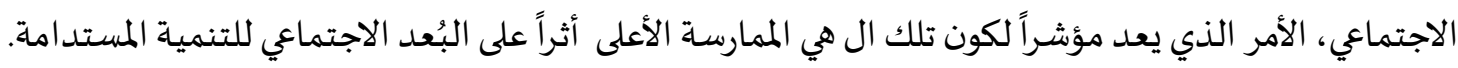
علاوة على ذلك يتضح من معاملات الارتباط بين المتغيرات المستقلة أن معامل الارتباط بين وظيفتي علاقات الموظفين

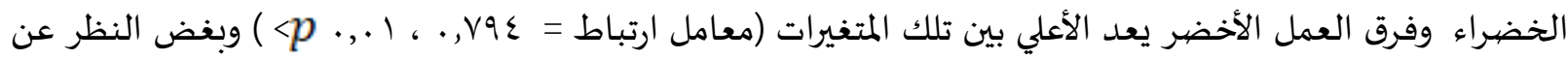
الدلالة الإحصائية لهذا المعامل إلا أنه ليس كبير بشكلٍ كافي (أصفر من 9,رو.) لتوقع وجود علاقات التعدد الخطي

Field, بين المتغيرات المستقلة (2013) Multicollinearity

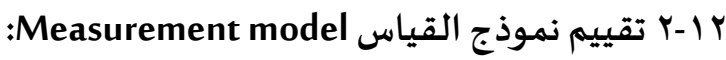
إن الهدف من تقييم نموذج القياس إنما يتمثل في تخفيض خطأ القياس إلى إدنى مستوى ممكن وذلك بشقية، العشوائي

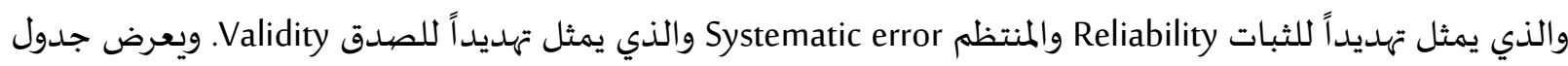
رقم (ع) النتائج الإحصائية لطريقة المربعات الصغرى الجزئية PLS المتعلقة بنموذج القياس. بداية وبمعلومية عدد

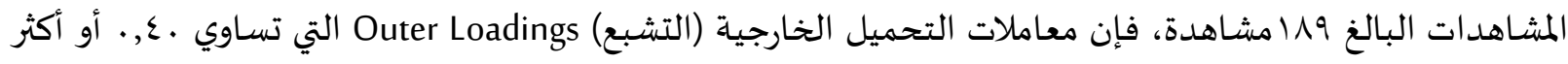

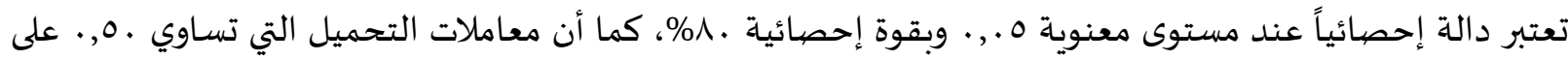

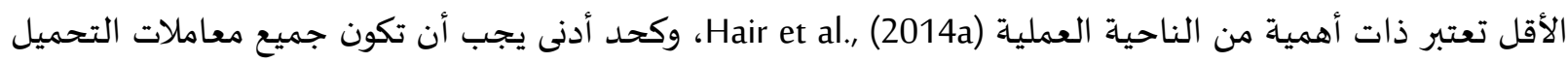

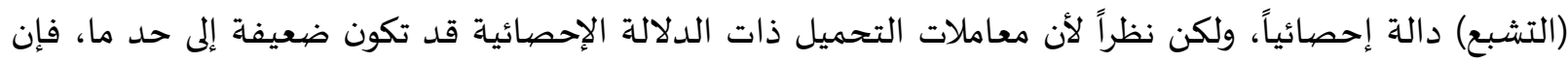

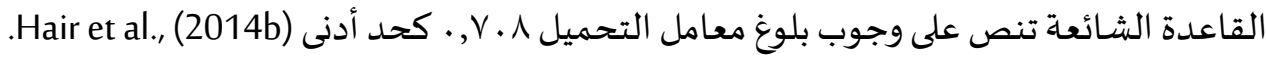




\begin{tabular}{|c|c|c|c|c|}
\hline \multirow{2}{*}{ (مؤشر الثبات المركب) الاتساق الداخلي } & \multicolumn{2}{|c|}{ 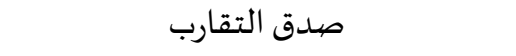 } & \multirow{2}{*}{ رقمم الفقرة } & \multirow[b]{2}{*}{ متغيرات البحث } \\
\hline & متوسط التباين & الخارجية (التشبع) التحميل & & \\
\hline \multirow{5}{*}{., $9 \leqslant 9$} & \multirow{5}{*}{$\cdot, \vee \wedge १$} &., $9 \leqslant Y 1$ & 1 & \multirow{5}{*}{ الاستقطاب والاختيار الأخضر } \\
\hline & &., $9 \ldots$ & r & \\
\hline & & $\cdot, \wedge \varepsilon \cdot \wedge$ & r & \\
\hline & & $\cdot, 9 \cdot \wedge r$ & $\varepsilon$ & \\
\hline & & $\cdot, \wedge \varepsilon \varepsilon \wedge$ & 7 & \\
\hline \multirow{2}{*}{., $91 \%$} & \multirow{2}{*}{$\cdot, \wedge \varepsilon}$. & $\cdot, \lambda \wedge \cdot r$ & 9 & \multirow{2}{*}{ التدريب والتنمية الأخضر } \\
\hline & &., $901 \mathrm{~V}$ & 1. & \\
\hline \multirow{4}{*}{.,$\wedge 9$} & \multirow{4}{*}{., $7 V}$. & . Aror & ir & \multirow{4}{*}{ إدارة الأداء الأخضر } \\
\hline & & $\cdot, \Lambda \varepsilon \mid r$ & $1 \varepsilon$ & \\
\hline & & $\cdot, \vee \varepsilon \wedge \vee$ & 10 & \\
\hline & & $\cdot, \wedge 0 \leqslant V$ & 17 & \\
\hline \multirow{4}{*}{$\cdot, 109$} & \multirow{4}{*}{., 7.0} & $\cdot, \vee \cdot \wedge l$ & IV & \multirow{4}{*}{ التعويضات الخضراء } \\
\hline & & $\cdot, \wedge \vee 10$ & 11 & \\
\hline & & $\cdot, \vee \neg \leqslant 0$ & 19 & \\
\hline & & .,, 017 & r. & \\
\hline \multirow{3}{*}{ 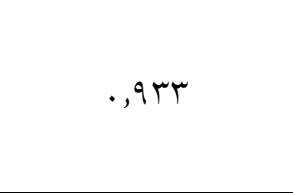 } & \multirow{3}{*}{. A Y TO } & $\cdot, \sqrt{ } 791$ & rt & \multirow{3}{*}{ الوصف الوظيفي الأخضر } \\
\hline & & $\cdot, 9 \vee \cdot 1$ & r & \\
\hline & & $\cdot, 9711$ & $T \varepsilon$ & \\
\hline \multirow{3}{*}{$\cdot, \wedge 71$} & \multirow{3}{*}{., 719} &., $9.9 r$ & ro & \multirow{3}{*}{ علاقات الموظفين الخضراء } \\
\hline & & $\cdot, 10 \vee 9$ & r & \\
\hline & & $\cdot, V .97$ & rq & \\
\hline \multirow{3}{*}{., $9 \leqslant 0$} & \multirow{3}{*}{$\cdot, 101$} & $\cdot, \wedge \vee \cdot\urcorner$ & r & \multirow{3}{*}{ فرق العمل الأخضر } \\
\hline & &., $970 \varepsilon$ & $r \varepsilon$ & \\
\hline & &., 9490 & ro & \\
\hline 1 & 1 & 1 & r & الثقافة الخضراء \\
\hline
\end{tabular}

يتبع في الصفحة التالية 


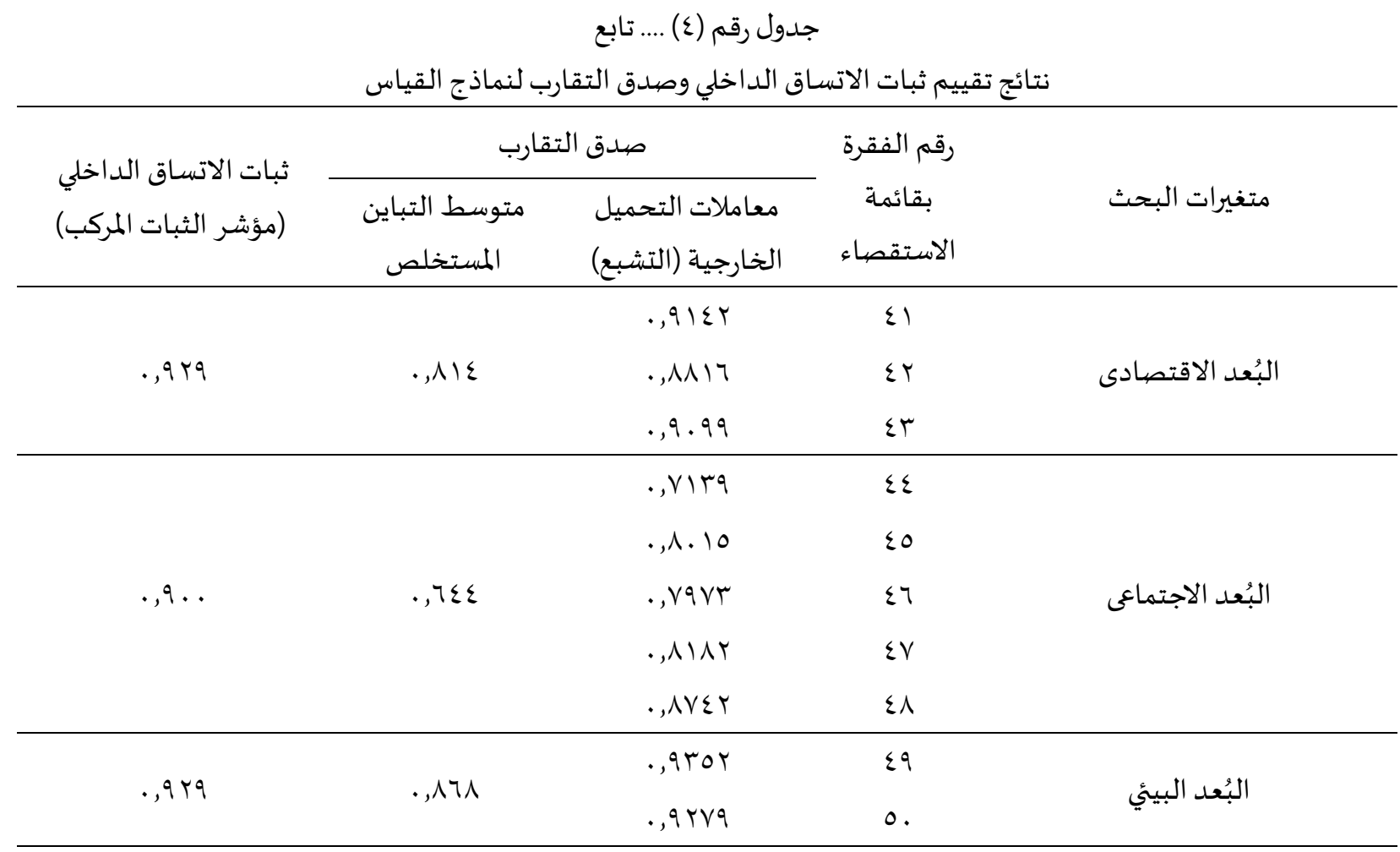

وبناءاً على ذلك قام الباحث باسقاط مؤشر واحد (الفقرة رقم 0 بقائمة الاستقصاء) من نموذج قياس الاستقطاب

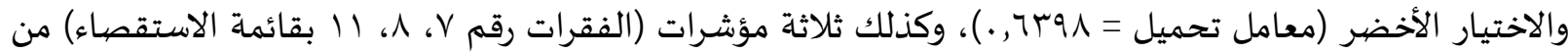

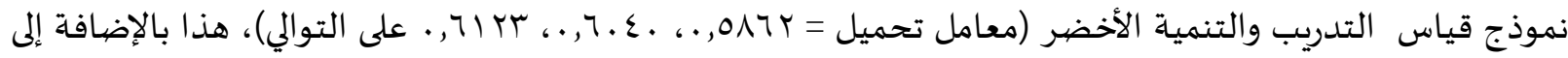

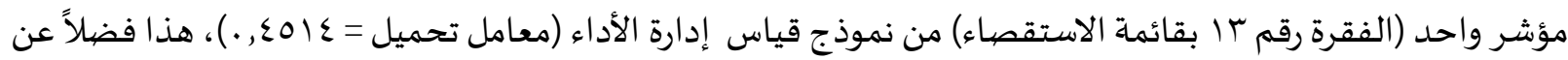

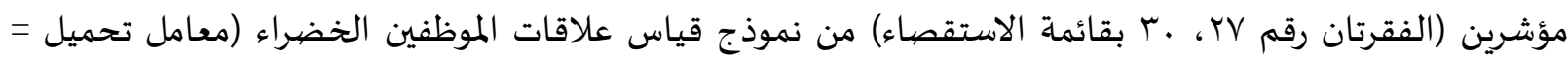

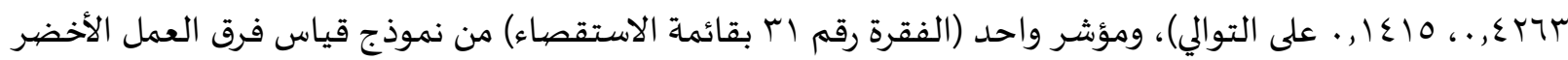

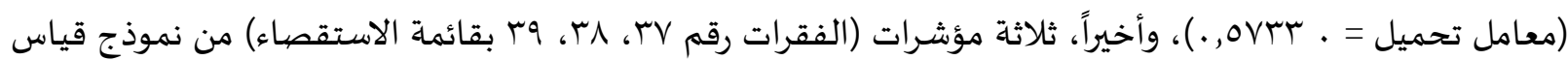

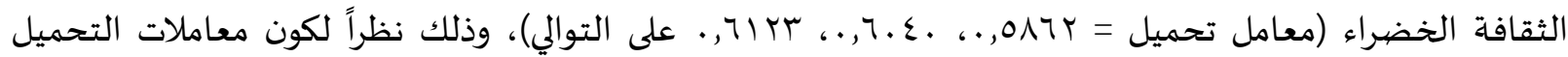

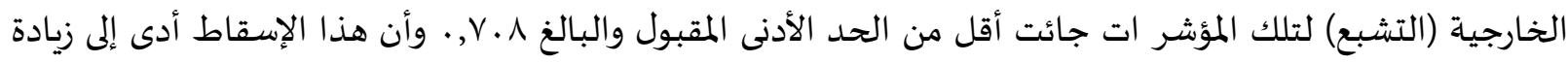

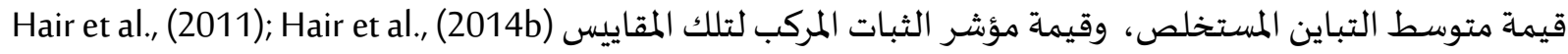

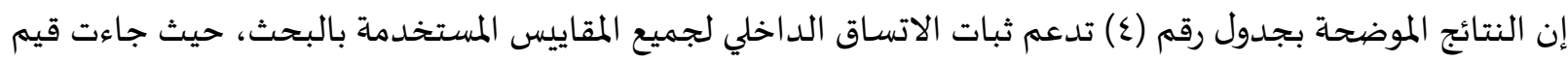

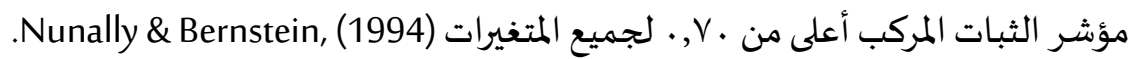

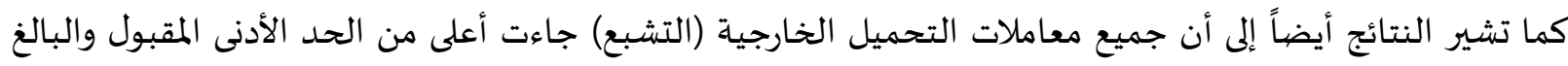

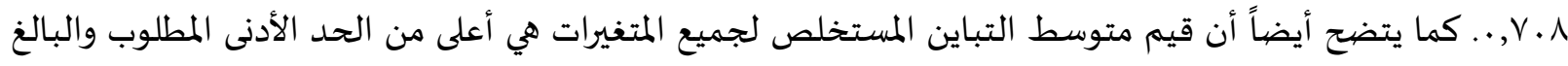
• o,.. هذه النتائج تعتبر دليلاً حاسماً على تحقق صدق التقارب لجميع متغيرات النموذج (2014b) مair et al., وأخيراً،

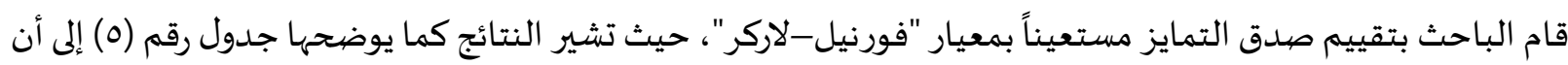
قيم الجذر التربيعي لمتوسط التباين المستخلص لمتغيرات البحث (القيم القطرية) جائت جميعها أعلى من معاملات 
الارتباط بين تلك المتغيرات وباقي المتغيرات الكامنة لنموذج المسار، مما يعد دليلاً على صدق تمايز جميع المتغيرات للبحث

.Fornell \& Larcker, (1981)

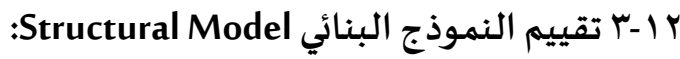

إن ثبات وصيدق نماذج القياس المستخدمة بالبحث تسمح بتقييم تقديرات النموذج البنائي، ووفقاً للمنهج المقترح من قبل كلٍ من .Henseler et al.,(2009). Hair et al,(2014 b) لتقييم النموذج البنائي، قام الباحث في البداية بتقييم علاقات التعدد الخطي بين المتغيرات المستقلة عن طريق أجراء تحليل إنحدار المربعات الصغرى الاعتيادي، وذلك باستخدام برنامج التحليل الإحصائي SPS 25 وطلب تشخيص علاقير المكات التعدد الخطي. 


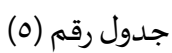

نتائج معيار "فورنيل-لاركر" لتقييم صدق التمايز لنماذج القياس

\begin{tabular}{|c|c|c|c|c|c|c|c|c|c|c|c|}
\hline متوسط التباين & البُعد البيئي & الاجتماعى البُعد & الاقتصادى البُعد & فرق العمل & الموظفين & الوالوضيفي & التعويضات الخضراء & الأدضر الأداء & الألتدريب & الأانتقطاب & متغيرات البحث \\
\hline ., $\vee \wedge 9$ & & & & & & & & & & $\cdot, \Lambda M$ & الأخضر الاستطاب والاختيار \\
\hline$\cdot, \wedge \varepsilon$. & & & & & & & & &., $91 V$ & . TVV & الأخضريب والتنمية \\
\hline . TV. & & & & & & & & $\cdot, 119$ & $\cdot, \mathrm{V}$. &., 701 & إدارة الأداء الأخضر \\
\hline., 7.0 & & & & & & & ., VYA & $\cdot, v \cdot q$ &., $0 \leq 9$ & . OrT & التعويضات الخضراء \\
\hline . Aro & & & & & & $\cdot, 9 \cdot 1$ & ( &.,$V \varepsilon \varepsilon$ & ., Vrq & . & الأخضف الوظيفي \\
\hline., 719 & & & & & . &.,$V \varepsilon r$ & ( & $\cdot, V \cdot Y$ &., 090 & . TVV & الخضاقات الموظفين \\
\hline .,101 & & & & (9T & .,$\vee 9 \varepsilon$ & ., VาV & .047 &., 211 & 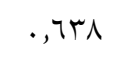 & . Vro & فرق العمل الأخضر \\
\hline . & & & $\cdot, 9 \cdot r$ & . Vr\& & . VTr &., 707 &., 011 & . &., 097 & . & البُعد الاقتصادى \\
\hline., $7 \varepsilon \varepsilon$ & & $\cdot, \Lambda \cdot r$ & $\cdot, \mathrm{YNI}$ & ., V70 & $\cdot, \mathrm{V} \cdot \mathrm{l}$ & .,701 &., $0 \leqslant V$ & . 70 . &., $0 \mathrm{VA}$ & . VRT & البُعد الاجتماعى \\
\hline 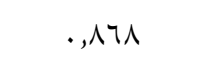 & (qTr &.,$V V \varepsilon$ & . V14 & . &., $1 \wedge$. & .,OTY & . EVY &., 07 & ., $\varepsilon V \varepsilon$ & אוTד, . & البُعدد البيئي \\
\hline
\end{tabular}


وبشكل أكثر تحديداً، قام الباحث بتقييم علاقات التعدد الخطي بالنسبة لوظائف الاستقطاب والاختيار الأخضر ،

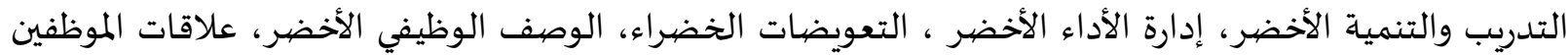

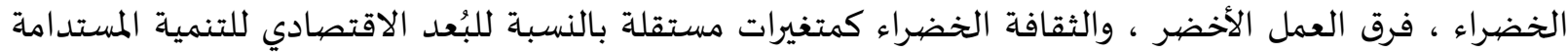

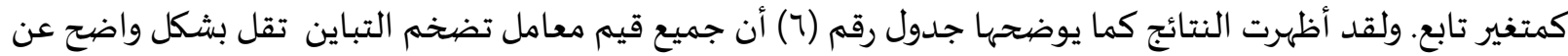

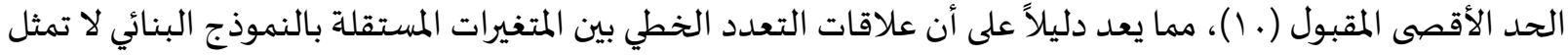

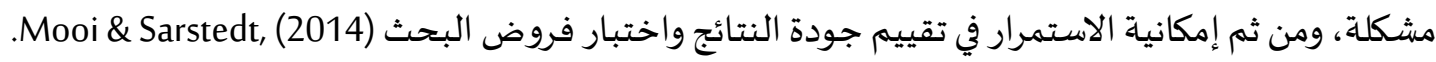

$$
\text { جدول رقم (7) }
$$

\begin{tabular}{|c|c|}
\hline معامل تضخم التباين & المتغيرات \\
\hline$r, 770$ & الاستقطاب والاختيار الأخضر \\
\hline$r, 1 \pi r$ & التدربب والتنمية الأخضر \\
\hline$r, 001$ & إدارة الأداء الأخضر \\
\hline T, & التعويضات الخضراء \\
\hline$\varepsilon, \wedge 9 \varepsilon$ & الوصف الوظيفي الأخضر \\
\hline$r, 7 \wedge 7$ & علاقات الموظفين الخضراء \\
\hline$\varepsilon, 00 \varepsilon$ & فرق العمل الأخضر \\
\hline $1,97 \pi$ & الثقافة الخضراء \\
\hline
\end{tabular}




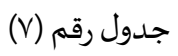

النتائج الإحصائية لطربقة المربعات الصغرى الجزئية PLS لتقييم النموذج البنائي واختبارات الفروض

\begin{tabular}{|c|c|c|c|c|c|c|c|c|c|c|}
\hline نتيـجة اختبار & $Q^{\mathrm{T}}$ & $R^{\bar{\tau}}$ & قيم P & قيم |t| - ق & الخطيأ & معاملات & & & المسـار & 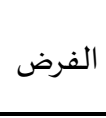 \\
\hline \multirow{9}{*}{ قبول الفرض } & & &.,.$r q$ & $r, 19 V$ &., .91 & $* ., r \ldots$ & البُعد الاقتصيادي & $\leftarrow$ & الاستقطاب والاختيار الأخضر & \multirow{9}{*}{$1 / 1$} \\
\hline & & &., $7 \leqslant 7$ &.,$\varepsilon 7$. &.,.$\vee \wedge$ & דr.., & البُعد الاقتصيادي & $\leftarrow$ & التدريب والتنمية الأخضر & \\
\hline & & & $\cdot, .71$ & $1, \lambda r 1$ &.,.$\wedge \vee$ & $\cdot, 17$ & البُعد الاقتصيادي & $\leftarrow$ & إدارة الأداء الأخضر & \\
\hline & & & $\cdot, v \cdot 9$ & $\cdot, r \vee \varepsilon$ &., .7 & 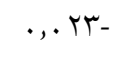 & البُعد الاقتصهادي & $\leftarrow$ & التعويضات الخضراء & \\
\hline & & &.,$\varepsilon 0 \leqslant$ & ., Vo. &.,.$\wedge 7$ &., $.7 \varepsilon-$ & البُعد الاقتصيادي & $\leftarrow$ & الوصف الوظيفي الأخضر & \\
\hline & & &.,$\ldots$ & $\varepsilon, \varepsilon .0$ &.,.$V V$ & $* * ., r \varepsilon$. & البُعد الاقتصيادي & $\leftarrow$ & علاقات الموظفين الخضراء & \\
\hline & & & $\cdot, \cdot r$ & $r, r \leq r$ &., 11 & $* .$, ro9 & البُعد الاقتصهادي & $\leftarrow$ & فرق العمل الأخضر & \\
\hline & & & $\cdot, \varepsilon \cdot \varepsilon$ & 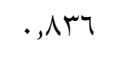 &., .00 &.,.$\leqslant 7-$ & البُعد الاقتصهادي & $\leftarrow$ & الثقافة الخضراء & \\
\hline &., 0.9 & ., $7 \varepsilon$. & & & & & & & & \\
\hline \multirow{9}{*}{ قبول الفرض } & & & $\cdot, \ldots 1$ & r &., $.9 \leq$ & **., rוr & البُعدد الاجتماعي & $\leftarrow$ & الاستقطاب والاختيار الأخضر & \multirow{9}{*}{$r / 1$} \\
\hline & & & $\cdot, r \cdot q$ & $1, .19$ &.,.$\times 1$ &.,$. V Y-$ & البُعـد الاجتماعي & $\leftarrow$ & التدريب والتنمية الأخضر & \\
\hline & & & • IV & 1,..r &.,.$\vee \vee q$ & $\cdot, . \vee \vee 9$ & البُعد الاجتماعي & $\leftarrow$ & إدارة الأداء الأخضر & \\
\hline & & & $\cdot, \cdot 10$ & $1, \vee Y q$ &., $.7 \wedge$ & $\cdot, 11 \mathrm{~V}$ & البُعد الاجتماعي & $\leftarrow$ & التعويضيات الخضراء & \\
\hline & & & $\cdot, r \leqslant 1$ & $1,1 V \varepsilon$ &., .91 & $\cdot, 1 \cdot V-$ & البُعد الاجتماعي & $\longleftarrow$ & الوصف الوظيفي الأخضر & \\
\hline & & &., .77 & $1,1 \leq 9$ & 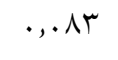 & ., 10r & البُعـد الاجتماعي & $\leftarrow$ & علاقات الموظفين الخضراء & \\
\hline & & & $\cdot, \ldots$ & $\varepsilon, 0 \wedge$ &., 1.1 & $* * ., \Sigma 7 r$ & البُعد الاجتماعي & $\leftarrow$ & فرق العمل الأخضير & \\
\hline & & &., .07 & 1,911 &., $.0 \varepsilon$ &., $1 \cdot \varepsilon-$ & البُعـد الاجتماعي & $\leftarrow$ & الثقافة الخضراء & \\
\hline & .,$\varepsilon r q$ &., 771 & & & & & & & & \\
\hline
\end{tabular}

يتبع في الصفحة التالية 
جدول رقم (V)..... تابع

النتائج الإحصائية لطريقة المربعات الصغرى الجزئية PLS لتقييم النموذج البنائي واختبارات الفروض

\begin{tabular}{|c|c|c|c|c|c|c|c|c|c|c|}
\hline نتيجة اختبار & $Q^{\tau}$ & $R^{\tau}$ & قيم ق ق ق & قيم |t| & المعياري & معاملات & & & المسار & الفرض \\
\hline \multirow{9}{*}{ قشبول الفرض جزئي } & & & $\ldots v$ & $r, V r q$ &., .97 & **., ז T & البُعدد البيئي & $\leftarrow$ & الاستقطاب والاختيار الأخضر & \multirow{9}{*}{$r / l$} \\
\hline & & & ., Vro & 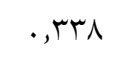 &., .94 & .,.r & البُعد البيئي & $\leftarrow$ & التدريب والتنمية الأخضر & \\
\hline & & & $\cdot, V \cdot V$ & . TVY &., .95 & .,. ro & البُعدد البيئي & $\leftarrow$ & إدارة الأداء الأخضر & \\
\hline & & &., 049 &., 717 &.,.$\times 1$ &.,.$\leqslant \varepsilon$ & البُعدد البيئي & $\leftarrow$ & التعويضيات الخضراء & \\
\hline & & &., 177 & $1, r q$ &., $1 . \varepsilon$ &., $1 \leq \varepsilon-$ & البُعدد البيئي & $\leftarrow$ & الوصف الوظيفي الأخضر & \\
\hline & & &.,$\ldots 1$ & r, r八o &., $.9 \mathrm{~V}$ & **.,rTV & البُعد البيئي & $\leftarrow$ & علاقات الموظفين الخضراء & \\
\hline & & & $\cdot, ., \varepsilon 9$ & $1,9 \vee 7$ &., 111 & $* .$, r/9 & البُعد البيئي & $\leftarrow$ & فرق العمل الأخضر & \\
\hline & & &., $1 \leqslant r$ & 1,879 & $\cdot, \cdot \vee \wedge$ &., $11 \varepsilon$ & البُعد البيئي & $\leftarrow$ & الثقافة الخضراء & \\
\hline & $\cdot, \varepsilon V V$ &., 000 & & & & & & & & \\
\hline
\end{tabular}

المصدر: من إعداد الباحث إستناداً إلى نتائج برنامج التحليل الإحصائي SmartPLS 2.0 
ويوضح جدول رقم (V) النتائج الإحصائية لطريقة المربعات الصغرى الجزئية PLS المتعلقة بالنموذج البنائي بالإضافة إلى ملخص لنتائج اختبار الفروض.إن المعيار الرئيسي لتقييم النموذج البنائي إنما يتمثل في معامل التحديد R2 . . إن قيم معامل

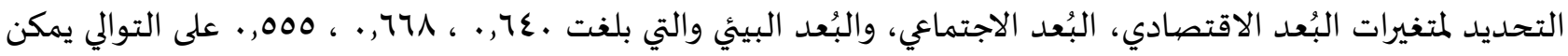

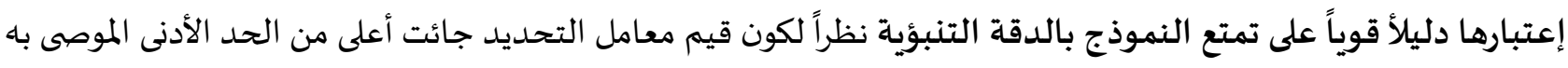

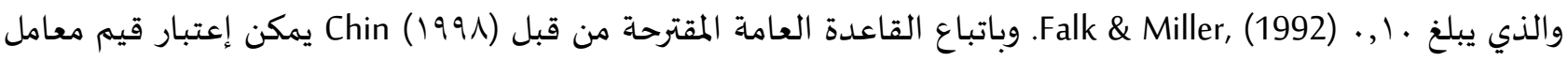

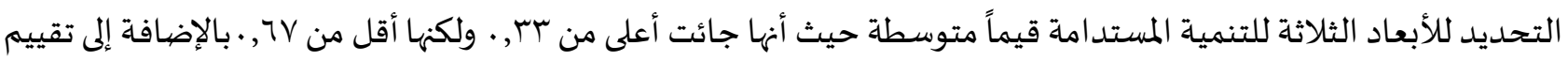

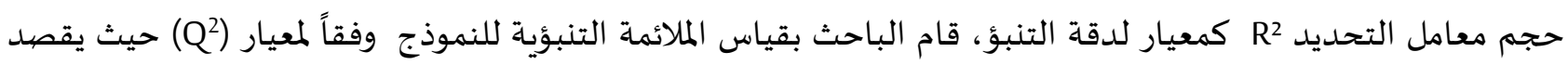

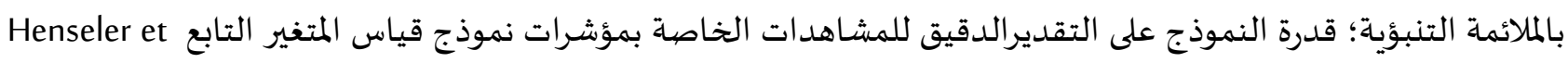

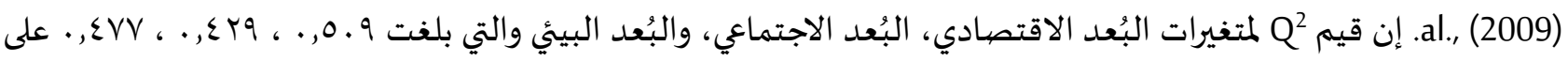

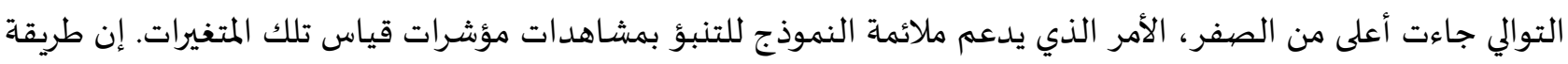

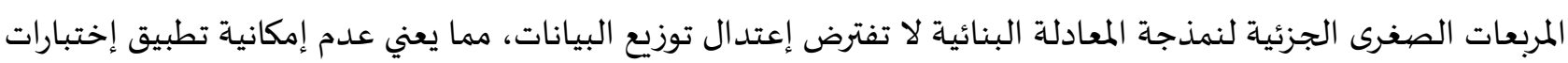

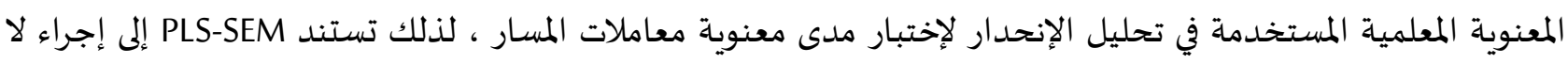

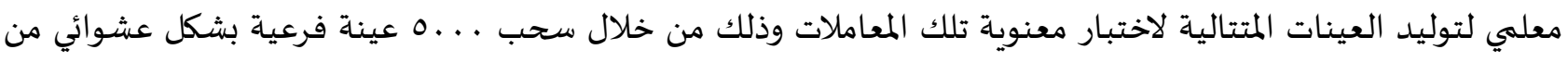

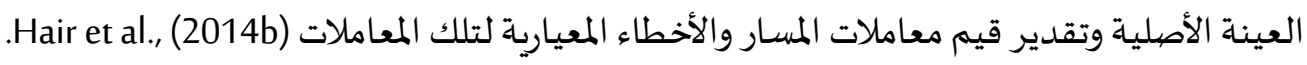

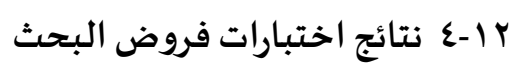
فيما يتعلق بالفرض الفرعي الأول للبحث (Ho) )، أظهرت النتائج التي يوضحها جدول رقم (V)، الأثر الإيجابي والمعنوي لوظائف الاستقطاب والاختيار الأخضر ، علاقات الموظفين الخضراء ، وفرق العمل الأخضر على البُعد الاقتصادي للتنمية المستدامة. وبشكل أكثر تحديداً، تعتبر وظيفة علاقات الموظفين الخضراء صاحبة الأثر الإيجابي الأعلى على البُعد الاقتصادي للتنمية

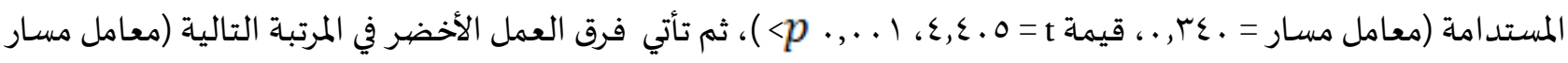

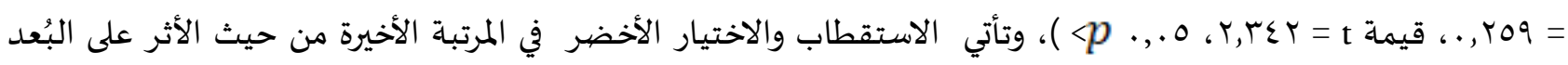

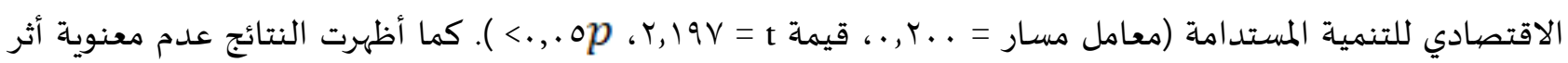
وظائف التدريب والتنمية الأخضر ، إدارة الأداء الأخضر، التعويضات الخضراء، الوصف الوظيفي الأخضر، والثقافة الخضراء على البُعد الاقتصيادي للتنمية. وقد أعزى الباحث عدم معنوية أثر وظائف التدريب والتنمية الأخضر، إدارة الأداء الأخضر، التعويضات الخضراء، الوصف الوظيفي الأخضر، والثقافة الخضراء كمتغيرات مستقلة على البُعد الاقتصادي للتنمية المستدامة كمتغير تابع وذلك على الرغم من وجود علاقات طردية قوية أو متوسطة القوة ذات دلالة إحصائية عند مستوى معنوية ا .,. تربط تلك الاستراتيجيات بالبُعد الاقتصبادي للتنمية المستدامة (أنظر جدول رقمَ) إلى أثر الوظائف الأخرى كمتغيرات مُعَدِلة. بناءاً على النتائج السـابقة، تم قبول الفرض الفرعي الأول للبحث (H1)، والذي ينص على أن الوظائف الخضراء لإدارة الموارد

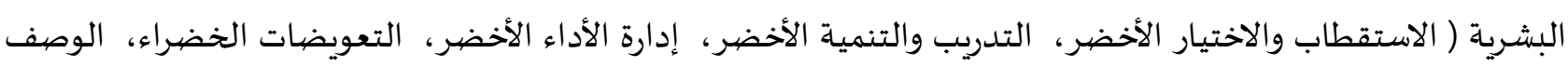

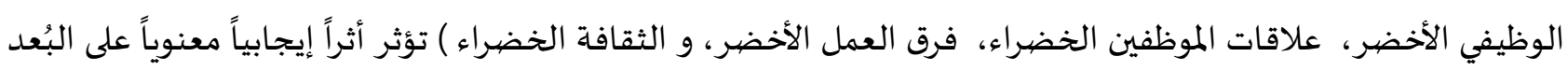
الاقتصادي للتنمية المستدامة وذلك بشكل جزئي فيما يتعلق بوظائف الاستقطاب والاختيار الأخضر، علاقات الموظفين 
الخضراء، وفرق العمل الأخضر ورفضية فيما يتعلق بوظائف التدريب والتنمية الأخضر ، إدارة الأداء الأخضر ، التعويضات الخضراء، الوصف الوظيفي الأخضر ، والثقافة الخضراء ،وفيما يتعلق بالفرض الفرعي الثاني للبحث (H2)، أظهرت النتائج التي يوضحها جدول رقم (7)، الأثر الإيجابي والمعنوي لوظيفتي الاستقطاب والاختيار الأخضر، وفرق العمل الأخضر على البُعد الاجتماعي للتنمية المستدامة. وبشكل أكثر تحديداً، تعتبر فرق العمل الأخضر صاحبة الأثر الإيجابي الأعلى على البُعد

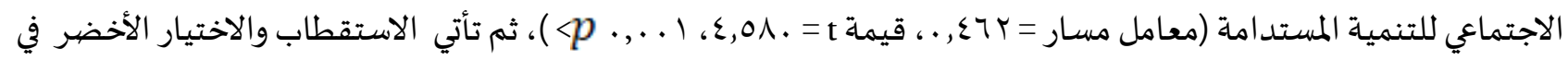

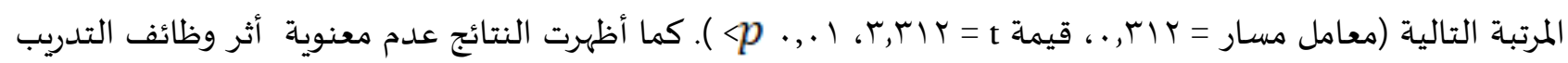
والتنمية الأخضر، إدارة الأداء الأخضر، التعويضات الخضراء، الوصف الوظيفي الأخضر، علاقات الموظفين الخضراء ، والثقافة الخضراء على البُعد الاجتماعي للتنمية المستدامة. وقد أعزى الباحث عدم معنوية أثر وظائف التدريب والتنمية الأخضر ، إدارة الأداء الأخضر ، التعويضات الخضراء، الوصف الوظيفي الأخضر ، علاقات الموظفين الخضراء ، والثقافة الخضراء كمتغيرات مستقلة على البُعد الاجتماعي للتنمية المستدامة كمتغير تابع وذلك على الرغم من وجود علاقات طردية قوية أو متوسطة القوة ذات دلالة إحصائية عند مستوى معنوية ا .,. تربط تلك الوظائف بالبُعد الاجتماعي للتنمية المستدامة (أنظر جدول رقمَr) إلى أثر الوظائف الأخرى كمتغيرات مُعَدِلة. بناءاً على النتائج السابقة، تم قبول الفرض الفرعي الثاني للبحث (H2)، والذي ينص على أن الوظائف الخضراء لإدارة الموارد البشرية ( الاستقطاب والاختيار الأخضر، التدريب والتنمية الأخضر ، إدارة الأداء الأخضر، التعويضات الخضراء، الوصف الوظيفي الأخضر، علاقات الموظفين الخضراء ، فرق العمل الأخضر ، والثقافة الخضراء ) تؤثر أثراً إيجابياً معنوياً على البُعد الاجتماعي للتنمية المستدامة وذلك بشكل جزئي فيما يتعلق بوظيفتي الاستقطاب والاختيار الأخضر ، وفرق العمل الأخضر ورفضة فيما يتعلق بوظائف التدريب والتنمية الأخضر، إدارة الأداء الأخضر، التعويضات الخضراء، الوصف الوظيفي الأخضر ، علاقات الموظفين الخضراء ، والثقافة الخضراء. أما فيما يتعلق بالفرض الفرعي الثالث للبحث (H ) أظهرت النتائج التي يوضحها جدول رقم (V)، الأثر الإيجابي والمعنوي لوظائف الاستقطاب والاختيار الأخضر ، علاقات الموظفين الخضراء ، وفرق العمل الأخضر على البُعد البيئي للتنمية المستدامة. وبشكل أكثر تحديداً، تعتبر وظيفة علاقات الموظفين الخضراء صاحبة الأثر الإيجابي الأعلى على البُعد البيئي للتنمية المستدامة

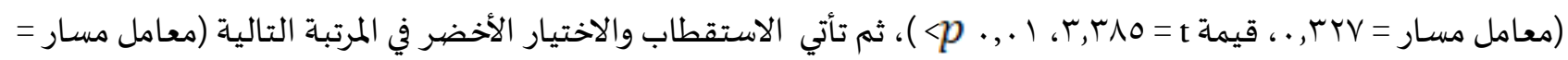

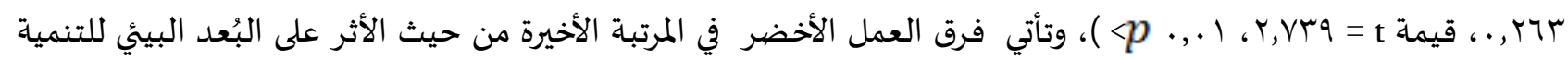

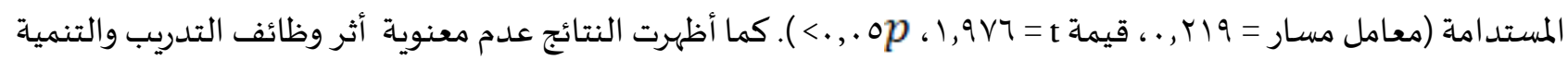
الأخضر، إدارة الأداء الأخضر ، التعويضات الخضراء، الوصف الوظيفي الأخضر ، والثقافة الخضراء على البُعد البيئي للتنمية.

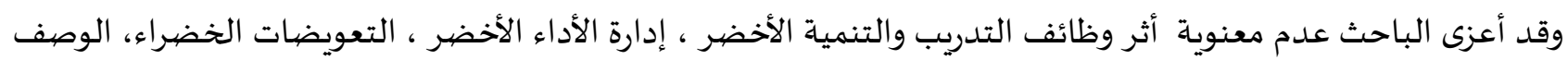
الوظيفي الأخضر ، والثقافة الخضراء كمتغيرات مستقلة على البُعد البيئي للتنمية المستدامة كمتغير تابع وذلك على الرغم من وجود علاقات طردية قوية أو متوسطة القوة ذات دلالة إحصائية عند مستوى معنوية ا..,. تربط تلك الوظائف بالبُعد الاقتصادي للتنمية المستدامة (أنظر جدول رقم ع) إلى أثر الوظائف الأخرى كمتغيرات مُعَدِلة. 
بناءاً على النتائج السـابقة، تم قبول الفرض الفرعي الثالث للبحث (H3) والذي ينص على أن الوظائف الخضراء لإدارة الموارد البشرية ( الاستقطاب والاختيار الأخضر، التدريب والتنمية الأخضر، إدارة الأداء الأخضر، التعويضات الخضراء، الوصف ، التف الوظيفي الأخضر ، علاقات الموظفين الخضراء، فرق العمل الأخضر ، والثقافة الخضراء ) تؤثر أثراً إيجابياً معنوياً على البُعد البيئي للتنمية المستدامة وذلك بشكل جزئي فيما يتعلق بوظائف الاستقطاب والاختيار الأخضر ، علاقات الموظفين الخضراء ، وفرق العمل الأخضر ورفضة فيما يتعلق بوظائف التدريب والتنمية الأخضر ، إدارة الأداء الأخضر ، التعويضيات الخضراء، الوصف الوظيفي الأخضر ، والثقافة الخضراء.

وبناء على ما سبق النتائج الاحصيائية النهائية لفروض البحث تم قبول الفرض الرئيسي للبحث، والذي ينص على أن الوظائف الخضراء لإدارة الموارد البشرية تؤثر إيجابياً معنوياً على التنمية المستدامة وذلك بشكل جزئي فيما يتعلق بأثر وظيفتي الاستقطاب والاختيار الأخضر، وفرق العمل الأخضر وعلاقات الموظفين الخضراء على التنمية المستدامة بأبعادها الثلاثة (الاقتصادي، الاجتماعي، والبيئي)، وكذلك بأثر علاقات الموظفين الخضراء على البُعد الاقتصادي والبيئي للتنمية المستدامة

ورفضية فيما عدا ذلك.

r ا -0 تفسير النتائج ومناقشتها

يمكن تفسيرومناقشّة النتائج التي أظهرتها نتائج التحليل الإحصيائي السابق على النحو التالي:

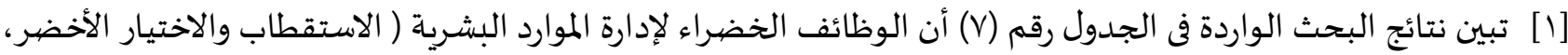

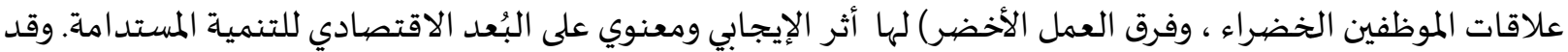
أتضح بشكل أكثر تحديداً، أن وظيفة علاقات الموظفين الخضراء تُعد صاحبة الأثر الإيجابي الأعلى على البُعد الاقتصادي

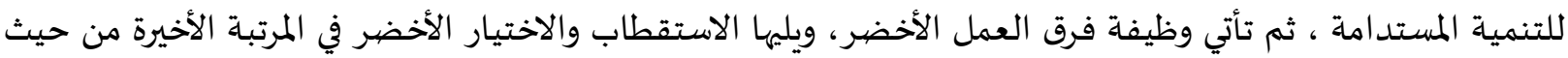

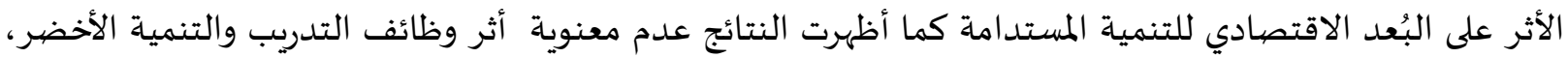
إدارة الأداء الأخضر، التعويضات الخضراء، الوصف الوظيفي الأخضر، والثقافة الخضراء على البُعد الاقتصيادي للتنمية

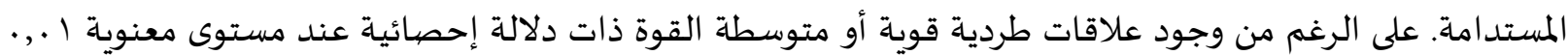
تربط تلك الاستراتيجيات بالبُعد الاقتصادي للتنمية المستدامة، وقد أرجع الباحث عدم معنوية أثر تلك تلك الوظائف

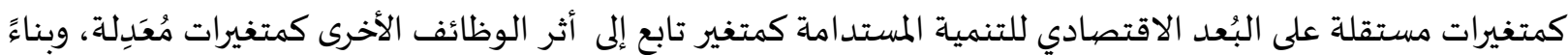
عليه تم قبول الفرض الفرعي الأول للبحث (Ho )، والذي ينص على أن الوظائف الخضراء لإدارة الموارد البشرية تؤثر إيجابياً

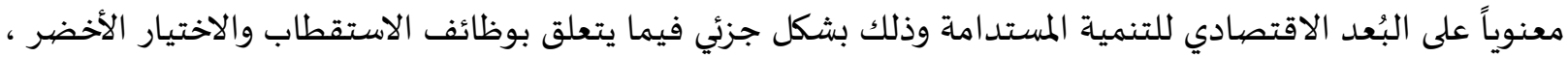
علاقات الموظفين الخضراء، وفرق العمل الأخضر ورفضة فيما يتعلق بوظائف التدريب والتنمية الأخضر، إدارة الأداء

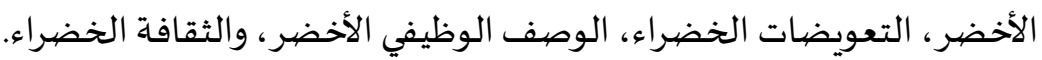

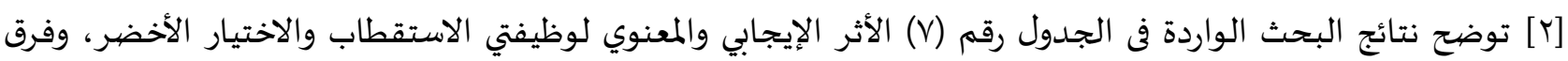

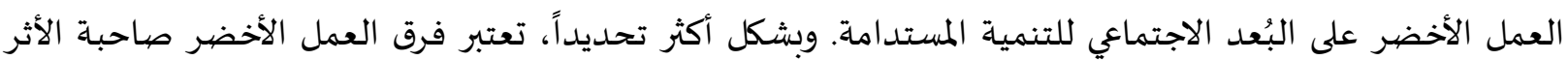

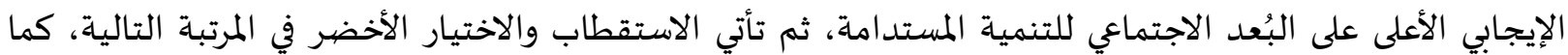

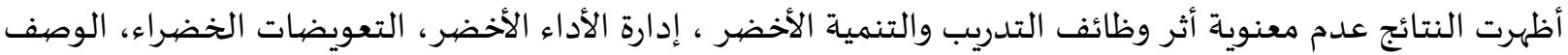

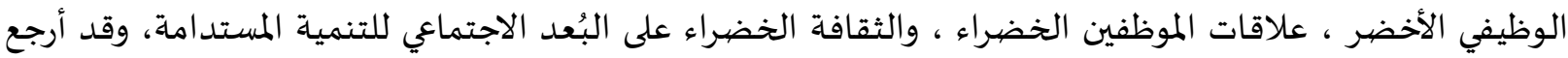

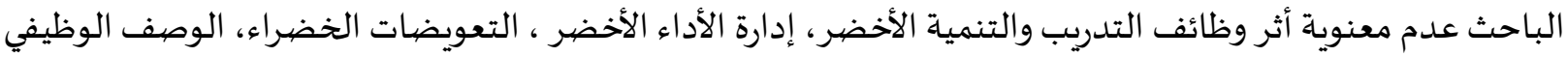


الأخضر، علاقات الموظفين الخضراء، والثقافة الخضراء كمتغيرات مستقلة على البُعد الاجتماعي للتنمية المستـدامة كمتغير

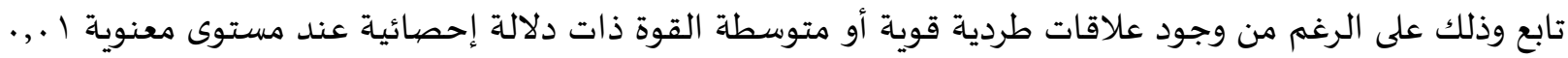

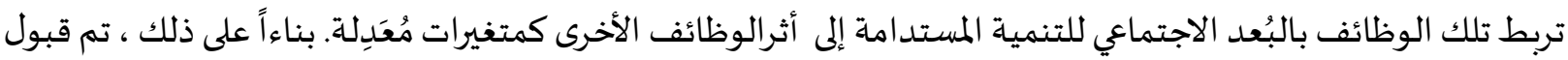

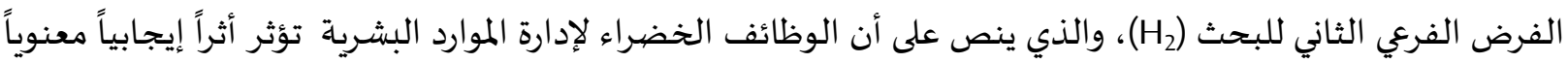

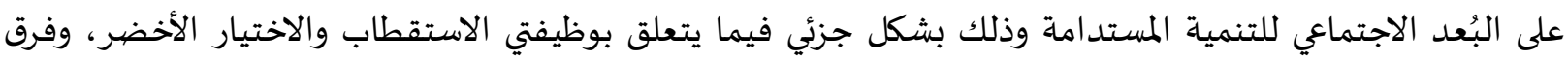

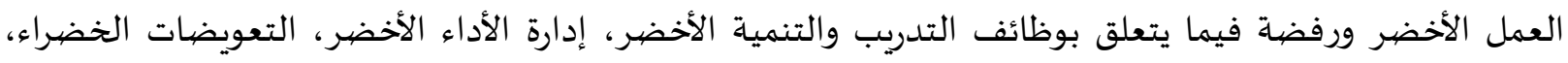

الوصف الوظيفي الأخضر، علاقات الموظفين الخضراء ،والثقافة الخضراء.

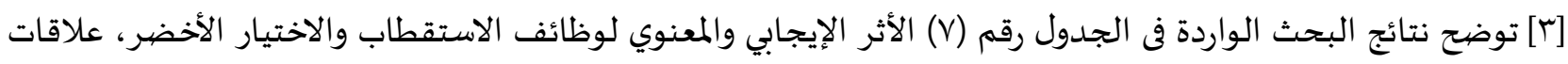

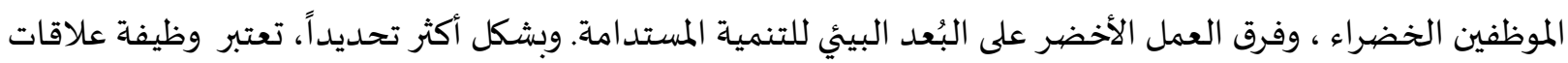

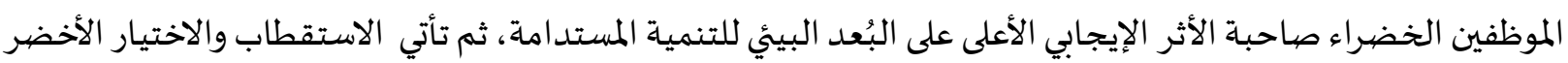

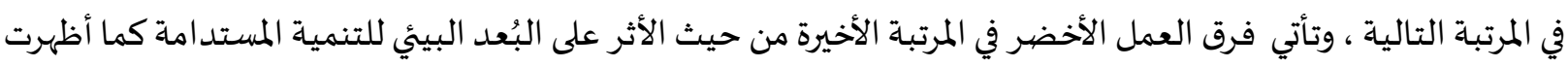

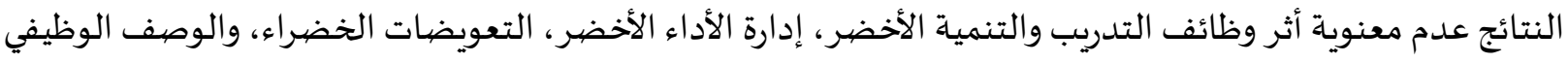

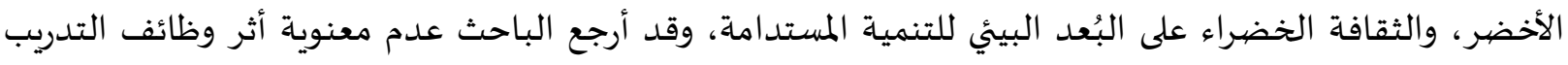

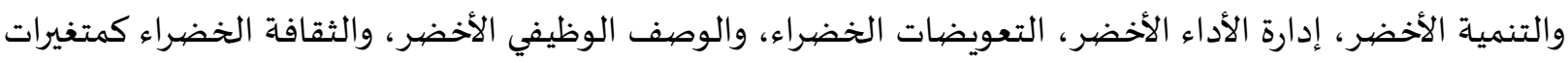

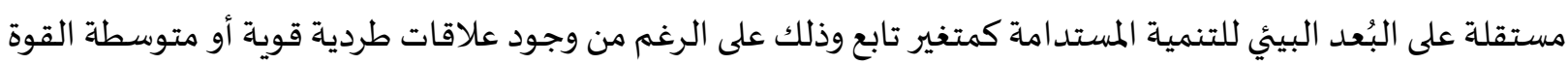

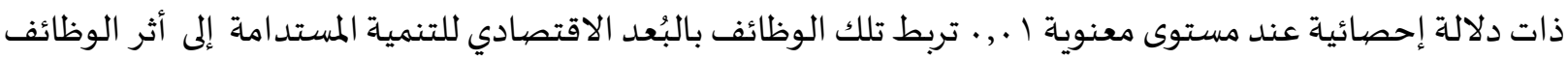

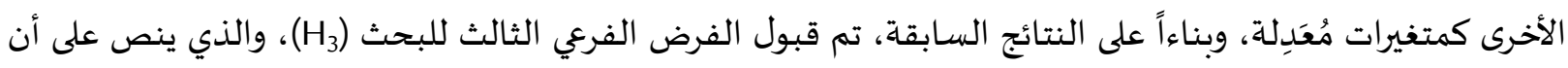

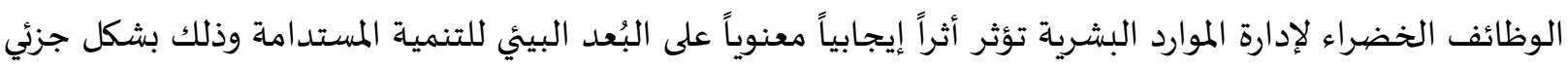

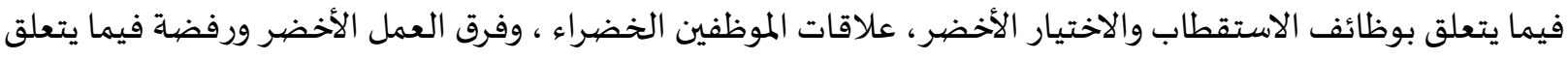

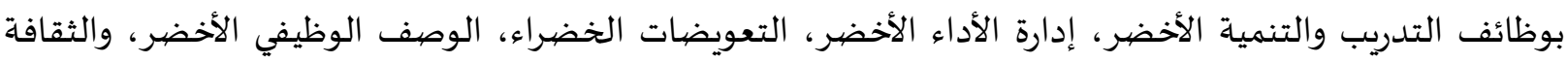
الخضراء.

[ـ] وبناء على ما تقدم من نتائج للفروض الفرعية للبحث تم قبول الفرض الرئيسي للبحث، والذي ينص على أن الوظائف

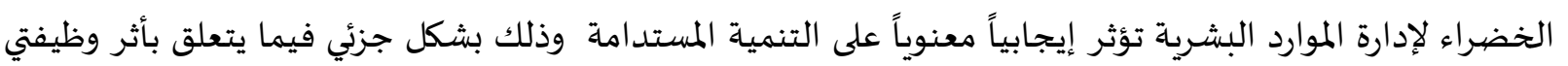

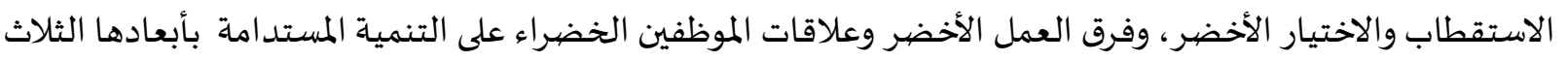

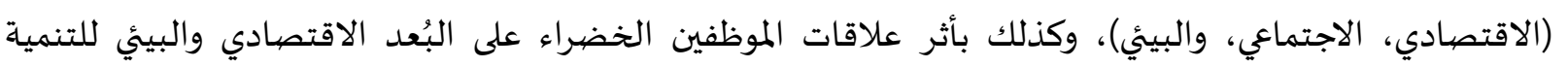

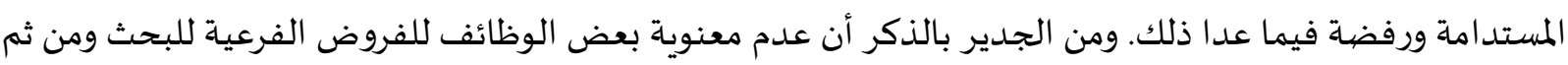

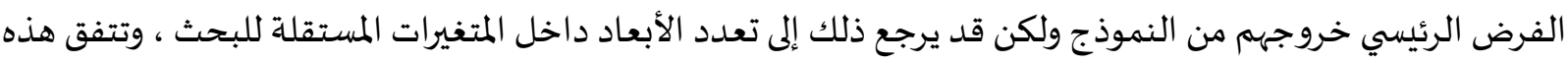

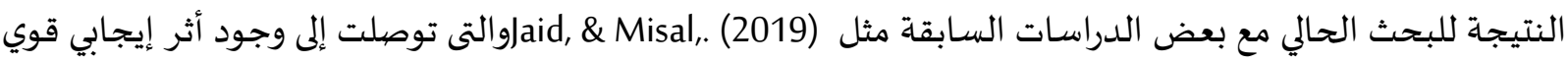
بشكل جزئي فيما يتعلق بالوظائف التعويض والمكافآت ادارة الاداء الأخضر ومشاركة الموظفين ورفضيه فيما يتعلق

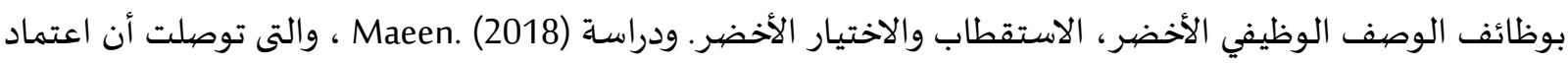

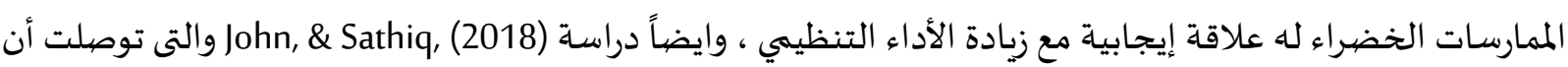

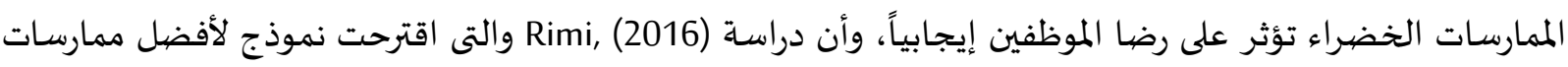

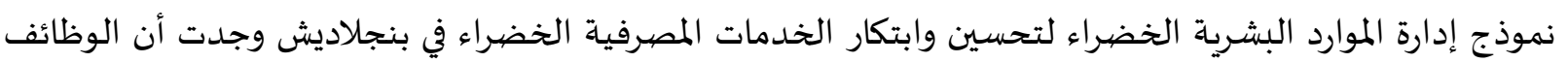


Chanderjeet الخضراء لها علاقة إيجابيةمع الوعي البيئي والرؤى النظرية للتنفيذ الفعال للخدمات الخضراء. ودراسة

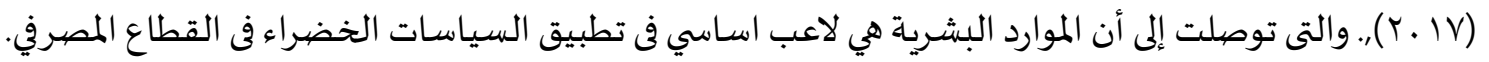

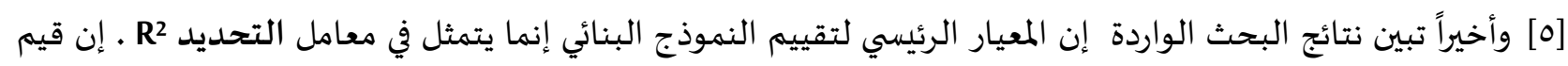

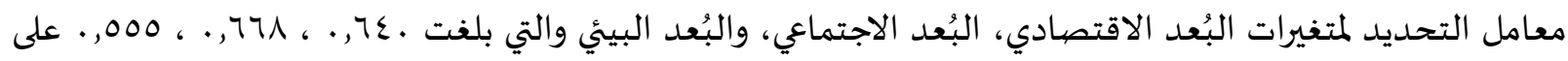

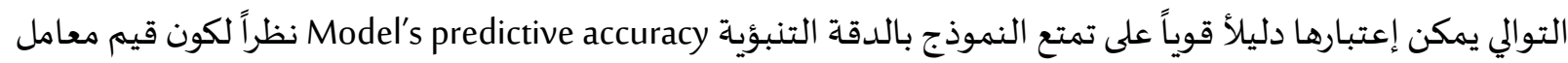

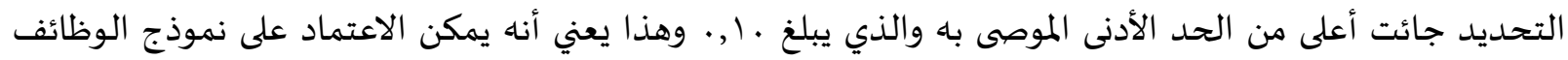

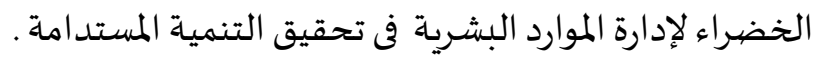

بار - توصيات البحث

فف ضوء ما كشفت عنه نتائج البحث الحالي، وبناءًا على ما قدمه الباحث من تفسير ومناقشة لنتائج البحث والتي أشارت إلى

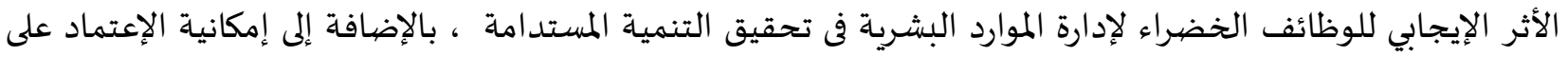

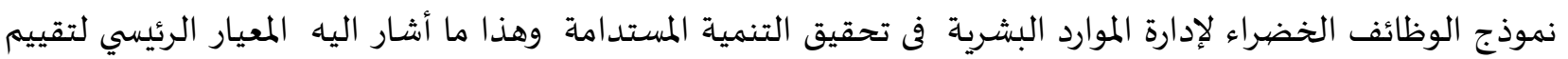
النموذج البنائي والذى تمثل في معامل التحديد R2 ، ميمكن للباحث أن يتقدم بنوعين من التوصيات هما: توصيات تطبيقية

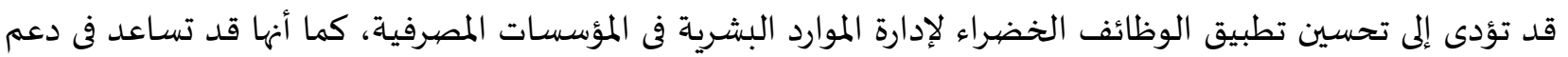

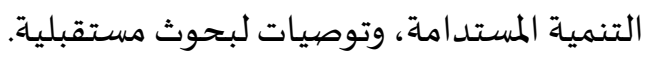
با إ-1 التوصيات التطبيقية

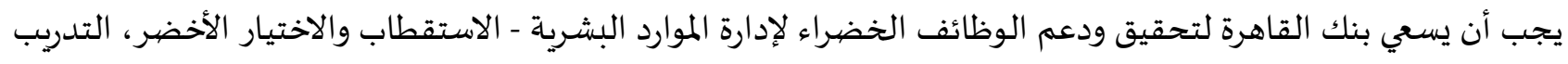

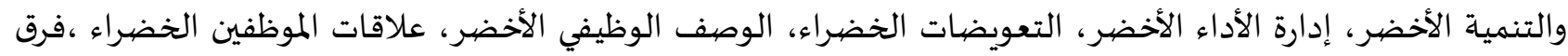
العمل الأخضر، والثقافة الخضراء - بصورة مجمعه بإعتبارها مكملة لبعضها البعض، لما لذلك من آثاردار إيجابية تحقيقاً

للتنمية المستدامة بأبعادها (الاقتصادي، الاجتماعي، الاخفراء البيئي) ا - يجب أن يسعي البنك، أن يقلل من استخدام الورق في عملية الاستقطاب والاختيار، وذلك بمساعدة التكنولوجيا الحديثة

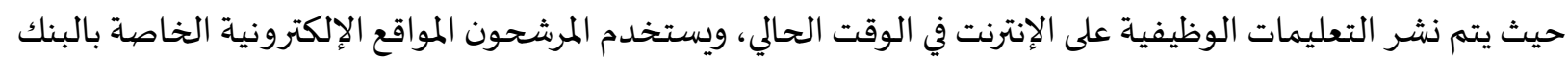

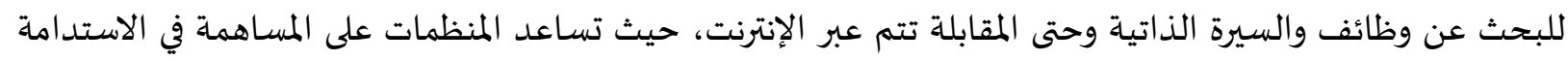
البيئية.

r- يجب عند تقديم توصيف وظيفي للإدارة البيئية الخضراء للموظفين من قبل إدارة الموارد البشرية بالبنك وأثناء اختيار الموظفين التأكيد على أن الوعي البيئي هو معيار الكفاءة.

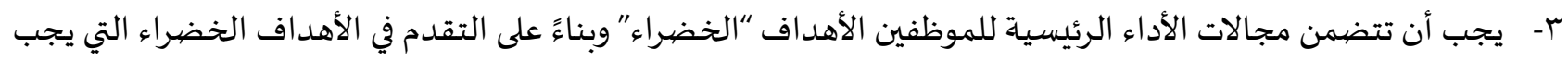
تقييم أداء الموظفين وفقاً لها. قد يكون هناك خيار لتطوير معايير الأداء الخضراء والتي يمكن أن تكون مقياس تقييم الأداء الأخضر للموظفين على جميع المستويات. يجب وضع أهداف وغايات ومسئوليات خضراء للمديرين وينبغي أن تنعكس درجة الإنجاز في التقييمات.

ع- يجب تطوير محتويات التدريب لزيادة كفاءات الموظفين والمعرفة في القضايا المتعلقة بالبيئة وينبغي أن تنعكس من خلال الممارسات وضرورة أن تتضمن خطط التدريب والتنمية برامج وورش عمل لتمكين الموظفين من تطوير واكتساب المعرفة في 
0- يجب تخصيص التعويضات لمكافأة اكتساب الموظفين للمهارات الخضراء وإنجازاتهم. يمكن تقديم مكافآت نقدية وعينية

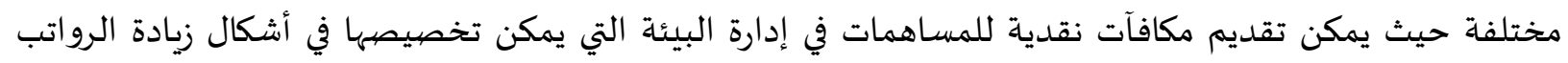
والحوافز النقدية والمكافآت بينما قد تشمل المكافآت العينية الإجازات الخاصة والهية والهدايا للموظفين وأفراد أسرهم. 7- إنشـاء مركز لريادة الأعمال لمساعدة الأفراد من جميع التخصصيات على بلدء أعمالهم علي أن تستند هذه الأعمال إلى أفكار

إبداعية بيئيًا.

V- يحتاج القطاع المصرفي إلى التركيز على استخدام إدارة الموارد البشرية لجعل موظفيه مستعدين ومختصين في أداء البيئة.

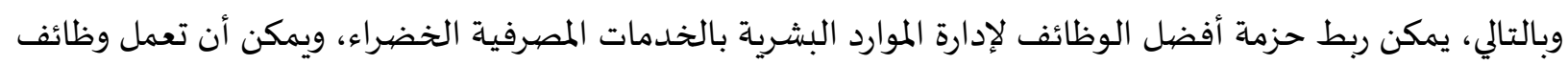
إدارة الموارد البشرية الخضراء كمصدر للتمييز من خلال تحفيز الخدمات الخضراء المبتكرة في القطاع المصرئي.

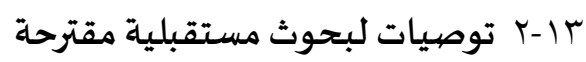
يوصي الباحث باقتراحات للباحثين للاهتمام بالجو انب التالية:

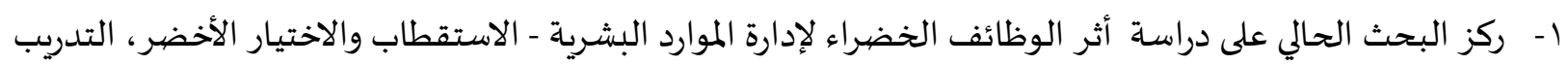

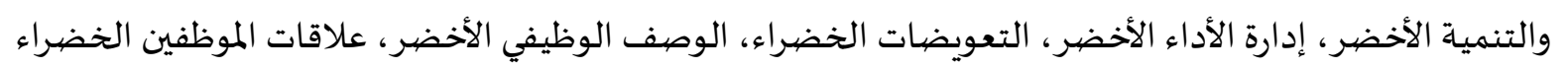

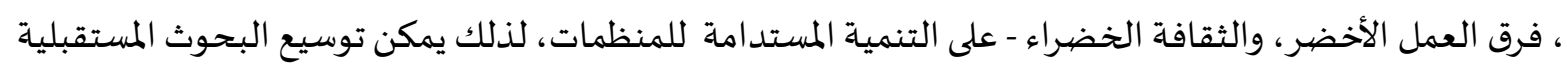

$$
\text { عن طريق دراسة بعض الوظائف الأخري لإدارة الموارد البشرية. }
$$

ץ- يقترح الباحث بإجراء بحوث مستقبلية تتضمن إضافة بعض المتفيرات الوسيطة مثل أبعاد الفكري الريادي ، الالتزام

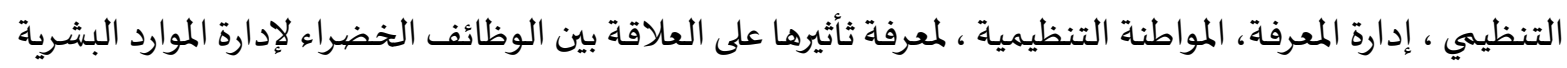

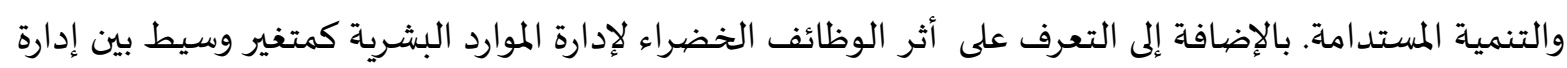

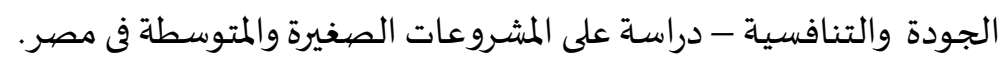

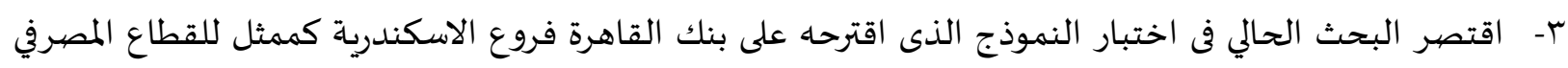
المصري، لذلك يمكن توسيع البحوث المستقبلية عن طريق اختبار ذلك النموذج في عدد من المنظمات المبات الصناعية مثل

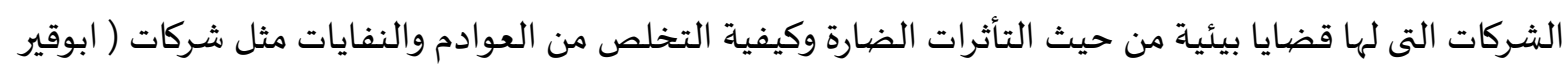

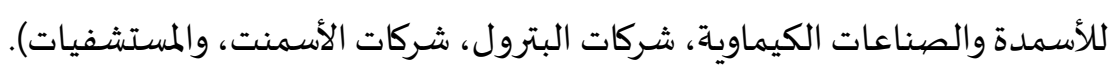

ع- يوصي الباحث أن تقوم البحوث المستقبلية بعمل دراسـة مقارنة عن طريق تقسيم الشركات العاملة في قطاع البترول

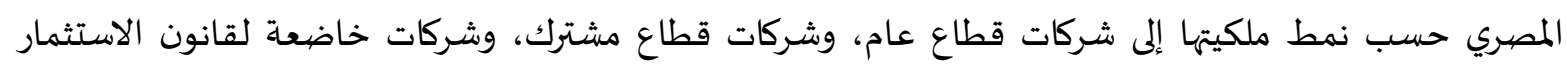

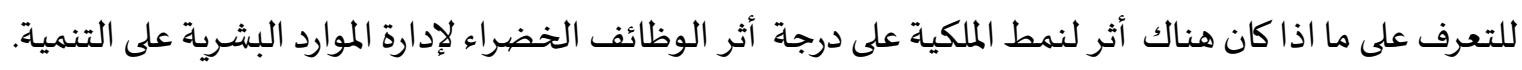

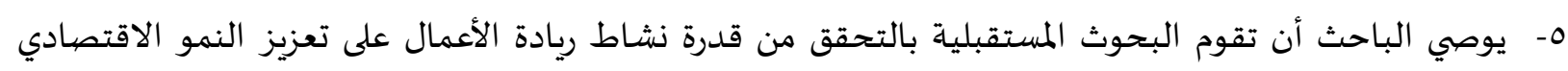

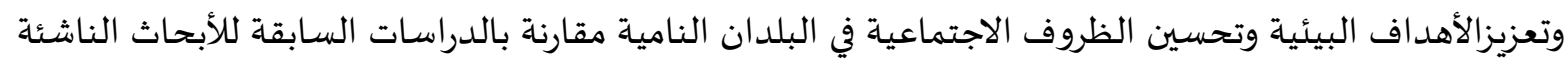
حول ريادة الأعمال والتنمية المستدامة. 


\section{المراجع}

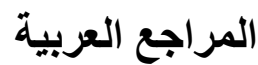

ا- الزبيدي، غني دحام تناي(17 (Y)، أثر ممارسات إدارة الموارد البشرية الخضراء في في تحقيق متطلبات المواطنة التنظيمية:

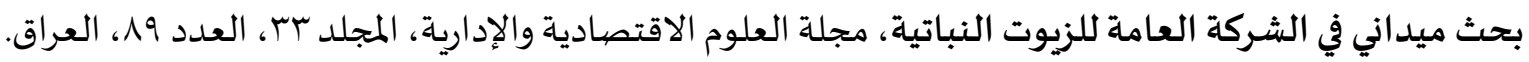

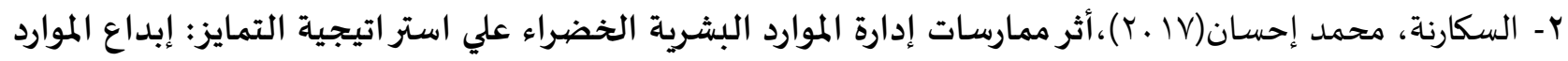

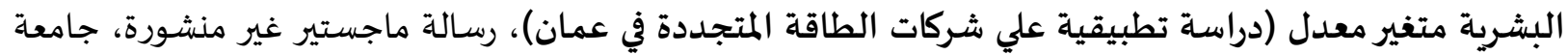

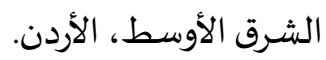

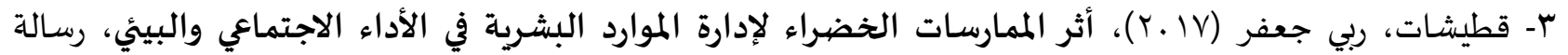

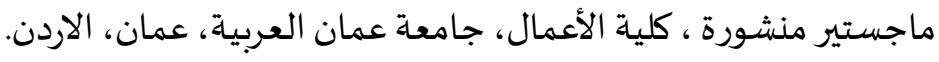
المراجع الأجنبية

- Arulrajah, A., Anton, O., \& Nawaratne, N. (2015). Green Human Resource Management Practices: A Review. Sri Lankan Journal of Human Resource Management, (1)5 pp.1-16.

- Bandara, W. (2018). Green Supply Chain Management Practices in Sustainable Development on Hospitality Industry in Sri Lanka", Master Thesis., Sri Lanka

- Basnett, Y. \& Bhattacharya, D. (2015). Exploring Spaces for Economic Transformation in the Sustainable Development Goals. Report $\odot$ Overseas Development Institute ODI, UK, 2015

- Bunting, G., \& Osborne, P. (2015). Sustainability Skills Survey: Staff Questionnaire, University of Wales, Trinity Saint David \& Swansea Metropolitan University, National HE STEM Programme.

- Chanderjeet (2017). Concept of Green HRM in Banking Industry, International Journal of Advance Research in Computer Science and Management Studies, India

- Chin, W. (1998). The partial least squares approach to structural equation modeling. Modern methods for business research, 295(2).

- Cohen, J. (1988). Statistical power analysis for the behavioral sciences. Mahwah, NJ: Lawrence Erlbaum.

- Cohen, J. (1992). A power primer. Psychological Bulletin, 112, 155-159.

- Darwish, M (2015). Sustainable Development: Using Sustainability - Green Building Education to Enable the Increase of Diversity in Construction Engineering, Copyright (c) American Society for Engineering Education, USA.

- Deepika R \& Dr. Karpagam., (2016). A study on green HRM Practices in an organization, international journal of Applied Research:2(8):426-429.

- Dernbach, J. \& Cheever, F. (2015). Sustainable Development and Its Discontents, University of Denver Strum College of Law, Legal Research Paper Series, Working Paper No. 15-33 
- Dikau, S. \& Volz, U. (2019). Central Bank Mandates, Sustainability Objectives and the Promotion of Green Finance, Department of Economics, SOAS University of London, UK

- Falk, R. \& Miller, N. (1992). A primer for soft modeling. University of Akron Press.

- Field, A. (2013). Discovering statistics using IBM SPSS statistics. SAGE.

- Fornell, C., \& Larcker, D. (1981). Evaluating Structural Equation Models with Unobservable Variables and Measurement error. Journal Of Marketing Research, 39-50.

- Gravetter, F., \& Wallnau, L. (2014). Essentials of statistics for the behavioral sciences. Wadsworth, Cengage Learning.

- Hair, J., Black, W., Babin, B., Anderson, R., \& Tatham, R. (2014a). Multivariate data analysis. Pearson Education Limited

- Hair, J., Hult, G., Ringle, C., \& Sarstedt, M. (2014b). A primer on partial least squares structural equation modeling (PLS-SEM). Sage Publications.

- Hair, J., Ringle, C., \& Sarstedt, M. (2011). PLS-SEM: Indeed, A Silver Bullet. Journal of Marketing Theory and Practice, 19, 139-151.

- Halawi, A \& Zaraket, W (2018). Impact of Green Human Resource Management on Employee Behavior, Journal of Applied Business Research, Lebanon

- Henseler, J., Ringle, C., \& Sinkovics, R. (2009). The use of partial least squares path modeling in international marketing. Advances in International Marketing, 20, 277-320.

- Human Development Report (2011). Sustainability and Equity: A Better Future for All, United Nations Development Program, USA, New York

- Hussain, A. (2018). Green Human Resource Management (GHRM) Practices in Organizations: A Comprehensive Literature Survey, Journal of Management Research and Analysis (JMRA), India.

- Igbudu, N., Garanti, Z. \& Popoola, T. (2018). Enhancing Bank Loyalty through Sustainable Banking Practices", Sustainability Journal

- Jabbour, C. (2013). Environmental training in organizations: From a literature review to a framework for future research. Resources, Conservation and Recycling, 74

- Jaid, R. \& Misal, A. (2019). An Empirical Study on Impact of Green Human Resource Functions on Environmental Performance: Case Study With Reference to ICICI Bank, Neville Wadia Institute of Management Studies \& Research, India

- John, F. \& Sathiq, N. (2018). A Study on the Influence of Green HR Practices on Employee Satisfaction among Selected Scheduled Banks, International Journal of Business and Management Invention, Vol. 7, Issue, 10, India 
- Klarin, T. (2018). The Concept of Sustainable Development: From its Beginning to the Contemporary Issues, Zagreb International Review of Economics \& Business, Vol. 21, No. 1, pp. 67-94

- Korzeb, Z. (2019). Sustainability Performance. A Comparative Analysis in the Polish Banking Sector, Sustainability Journal

- Krejcie, R \& Morgan, D.(1970).Determining sample size for research activities. Educational and Psychological Measurement, 30,607-610.

- Krstic, I. \& Avramovic, D. (2018). The Three Dimensions of Sustainable Development Environment, Economy and Society, 50 Years of Higher Education, Science and Research in Occupational Safety Engineering, 6-7 December, 2018, Niš, Serbia

- Kumar and Prakash (2019). Examination of Sustainability Reporting Practices in Indian Banking Sector, Asian Journal of Sustainability and Social Responsibility

- Maeen Uddin. (2018). Practicality of Green Human Resource Management Practices: A Study on Banking Sector in Bangladesh, Vol. VI, Issue 6, International Journal of Economics, Commerce and Management, UK

- Mashala, Y. L. (2018). Green Human Resource Management and Environmental Sustainability in Tanzania: A Review and Research Agenda., International Journal of Academic Multidisciplinary Research (IJAMR)

- Masocha, R. (2019). Social Sustainability Practices on Small Businesses in Developing Economies: A Case of South Africa, Sustainability Journal.

- Mensah, J. (2019). Sustainable development: Meaning, history, principles, pillars, and implications for human action: Literature review, Cogent Social Sciences

- Mooi, E. \& Sarstedt, M. (2014). A Concise Guide to Market Research: The Process, Data, and Methods Using IBM SPSS Statistics. Berlin: Springer.

- Moraes, S., Jabbour, C., Battistelle, R., Rodrigues, J., Douglas S., Renwick, Foropon, C. and Roubaud, D. (2018). When Knowledge Management Matters: Interplay between Green Human Resources and Eco-efficiency in the Financial Service Industry., Emerald Publishing Limited, Journal of Knowledge Management, Brazil

- Nunally, \& Bernstein, (1994). Psychometric theory. New York: McGraw-Hill.

- Rani, Sushma., Mishra, K. (2014). Green HRM: Practices and Strategic Implementation in the Organizations, International Journal on Recent and Innovation Trends in Computing and Communication, Vol. 2 Issue: 11.

- Renwick, D. Redman, T. and Maguire, S. (2008). Green HRM: A Review, Process Model, and Research Agenda, University of Sheffield Working Paper. http://www.sheffield.ac.uk/content/1/c6/08/70/89/200801.pdf. 
- Rimi, N. N. (2016). Green HRM for Green Services: A Proposed Best Practices Green HRM Model for Green Banking Performance in Bangladesh, European Journal of Business and Management, Vol. 8, Issue. 8, Bangladesh

- Rimi, Nadia., Yusoff, Yusliza (2015). Green Human Resource Management in Service Organizations: A Proposed Model for Green Banking Performance, Conference on Green Human Resource Management, Eastin Hotel, Penang, Graduate School of Business (GSB), US, Malaysia 30 May.

- Ringle, C., Wende, S. \& Will, A. (2005) Smart PLS 2.0 (Beta), Hamburg, available at http://www.smartpls.de

- Romiguer, AlexandreTorres (2011). Sustainable Development: Objectives, Enablers and Challenges for Spanish Companies, Unpublished Master Thesis, Tampere University of Technology, Spain

- Sarode, A., Patil, Jayashree., \& Patil, Deepak Tulsiram (2016). A study of Green HRM and Its Evaluation with Existing HR Practices in Industries within Pune Region, International Journal of Research in Engineering, IT and Social Sciences, Vol. 6, Issue 04. p.p.49-67

- Schoolman, E., Guest, J, Bush, K. \& Bell, A. (2012). How Interdisciplinary is Sustainability Research? Analyzing the Structure of an Emerging Scientific Field., Sustain Sci. 7(1):67-80

- Shah, M. (2019). Green Human Resource Management: Development of a Valid Measurement Scale, John Wiley \& Sons, Ltd and ERP Environment, USA.

- Sunita, M. (2017). Green HRM: A Study of Indian Banks, International Journal of Research in IT and Management, Vol. 7, Issue. 4, India

- Tang, G., Chen, Y., Jiang, Y., Paillé, P., \& Jia, J. (2017). Green human resource management practices: scale development and validity. Asia Pacific Journal of Human Resources.

- Vincenzo, F., Marialusia, S. \& Fransesco, C. (2017). The Role of Banks in the Sustainable Development of Territory: An Ecosystems View, World Organization of Systems and Cybernetics (WOSC), Rome

- Volz, U. (2018). Fostering Green Finance for Sustainable Development in Asia, Asian Development Bank Institute, Working Paper Series

- Whitfield, K. (2015). Quick Guide to Sustainable Development: History \& Concepts., Research Service, National Assembly for Wales, Cardiff, E-mail: Karen.whitfield@ assembly.wales.

- Wu, J., Guo, S., Huang, H., Liu, W. and Xiang, Y. (2018). Information and Communications Technologies for Sustainable Development Goals: State-ofthe-Art, Needs and Perspectives, IEEE Press

- Zimmermann, S. (2019). Same Same but Different: How and Why Banks Approach Sustainability, Sustainability Journal. 


\section{ملاحق البتحث}

\section{ملحق رقم(1)}

قائمة إستقصياء

\section{السـادة / المشـاركون}

يقوم الباحث بإجراء دراسة بعنوان " أثر الوظائف الخضراء لإدارة الموارد البشرية على التنمية المستدامة: دراسة تطبيقية على فروع بنك القاهرة بمحافظة الاسكندرية" وذلك بهدف التعرف على أثر الممارسات الخضراء لإدارة الموارد البشرية على لئل

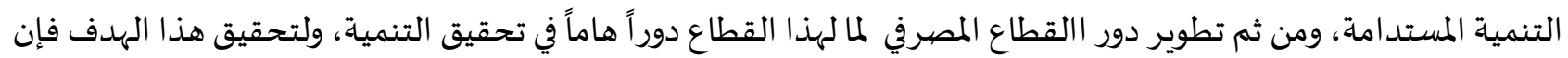
الباحث يتطلع ويقدر مساهمتكم في إتمام الدراسة وذلك بالإجابة على مجموعة الأسئلة الواردة بالقائمة، علماً بأن تلك الأسئلة لا تتطلب الإجابة عنها الإدلاء بأية بيانات شخصية أو سرية فضلاً عن عدم إستخدا امها إلا في أغراض البحث البح العلمي.

\section{مع خالص الشكروالتقديرسلفاً}

الباحث 
إلى أي مدى تتفق أو تختلف مع كل عبارة من العبارات التالية؟ برجاء وضع علامة ( ل) أمام الإجابة المناسبة

\begin{tabular}{|c|c|c|c|c|c|c|}
\hline مو افير & 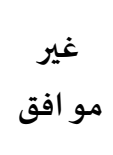 & محايد & 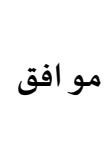 & مو افق & 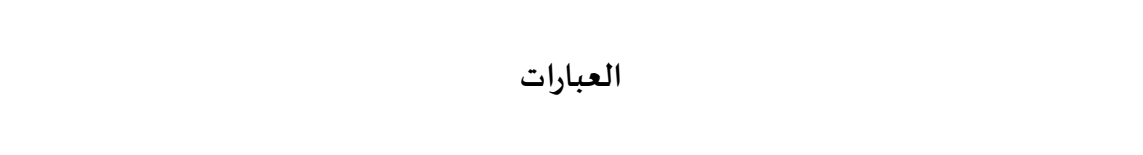 & r \\
\hline & & & & & يتم جذب المرشحين للوظائف الخضراء الذين يستخدمون المعايير الخضراء & .1 \\
\hline & & & & & تشتمل وظيفة الاستقطاب على المعايير البيئية &.$r$ \\
\hline & & & & & المتقدمون في عملية الاختيارعلى وعي بالممارسـات الخضراء & r \\
\hline & & & & & أفهم ما يعنيه مفهوم الوظائف الخضراء لإدارة الموارد البشرية & $\varepsilon$ \\
\hline & & & & & يتم استخدام المقابلة الشخصية الشفهية مع إدخال الجو انب الرسمية & .0 \\
\hline & & & & & تلمتلك الموارد البشرية في البنك رؤي وتصهورات حول الوظائف الخضراء وتستخدم المعايير & .7 \\
\hline & & & & & يتم وضيع القضبايا/المشكلات البيئية في الاعتبارعند إجراء التدريب &.$v$ \\
\hline & & & & & يتم وضع برامج للمرشحين مخصصية للقضشايا/المشكلات البيئية &.$\wedge$ \\
\hline & & & & & ت ت تو افرمواد التدريب عبر الإنترنت & .9 \\
\hline & & & & & يتم توفير مواد التدريب في نسخ إلكترونية بدلاً من الورقية & .1 . \\
\hline & & & & & يعمل البنك على إنشاء وتطويربناء الجدارات الشخصية الخضراء & .11 \\
\hline & & & & & نحن نستخدم مؤشرات الأداء الأخضرفى نظام تقييم الأداء & .14 \\
\hline & & & & & يحدد البنك أهداف ومسؤوليات خضراء للمديرين والعاملين & .14 \\
\hline & & & & & يتم توجيه التغذية المرتدة إلى الموظفين لتحسين سلوكههم الأخضر & $.1 \varepsilon$ \\
\hline & & & & & في البنك، يحدد المديرون أهدافا لتحقيق النتائج الخضراء المدرجة في التقييمات & .10 \\
\hline & & & & & فى البنك توجد معوقات فى نظام إدارة الأداء لعدم تلبية أهداف الإدارة البيئية & .17 \\
\hline & & & & & نحنت نجعل المنافع الخضراء (النقل/السفر) بدلاً من إعطاء بطاقات مسبقة الدفع لشراء & $.1 \mathrm{~V}$ \\
\hline & & & & & 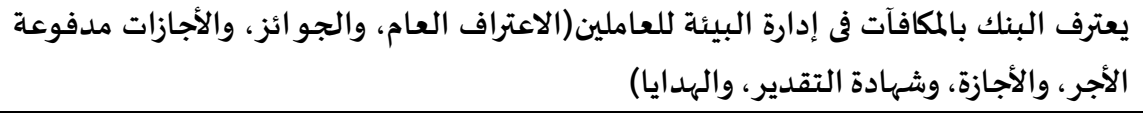 & .11 \\
\hline & & & & & يعطيك البنك الحرية في تعديل أو إنشاء ممارسات جديدة صديقة للبيئة & .19 \\
\hline & & & & & يوفر البنك نماذج طلب الإجازات عبر الإنترنت &.$r$. \\
\hline & & & & & فى البنك، يتم تحديد التعويضـات آخذاً بعين الاعتبار المسـاهمات البيئية &.$M$ \\
\hline & & & & & يشمل الوصف الوظيفي جو انب ترتبط بالممارسات الخضراء الخاصة بالبيئة &.$r$ \\
\hline & & & & & لكافة الوظائف الإدارة على الاهتمام بالقضشايا الخضراء(المحافظة على البيئة) فى الوصف الوظيفي & r \\
\hline & & & & & على السجلات الوصف الوظيفي أدوات صديقة للبيئة مثل استخدام التكنولوجيا بدلاً من الاعتماد &.$r \varepsilon$ \\
\hline & & & & & التعرف على الدور المشترك في الإدارة البيئية بين الموظفين والإدارة. & ro \\
\hline & & & & & إشراك الموظفين في مخططات الاقتراحات الخضراء. &.${ }^{\top}$ \\
\hline & & & & & يتم عمل مشاورات مشتركة في حل القضايا البيئية للمنظمة. &. $\mathrm{rV}$ \\
\hline & & & & & تتم مشاركة المكاسب فيما يتعلق بالمبادرات أو البرامج البيئية. &. $\mathrm{M}$ \\
\hline & & & & & هناك مناخ للتعلم المتبادل بين العاملين للسلوك الأخضروالتوعية به في البنك. &.$r 9$ \\
\hline
\end{tabular}




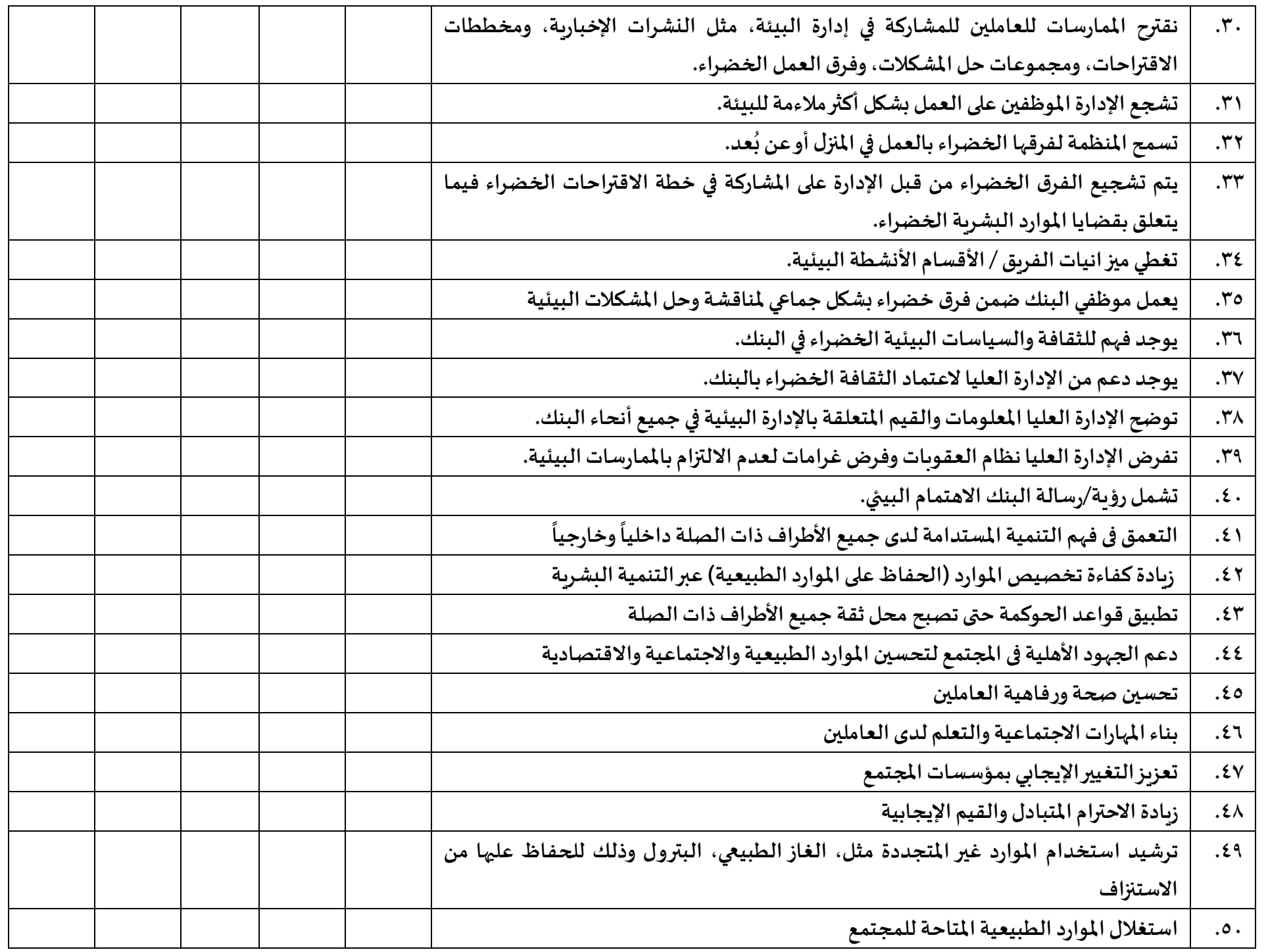

ثانياً: بيانات شخصية

\begin{tabular}{|c|c|c|c|c|c|c|}
\hline & & & & & الإسم (إختياري) & 1 \\
\hline & & 口 انثي & & ل & النوع & $r$ \\
\hline 口 و وظائف نمطية & ف لـائب مدير & 口 ل نائب مديرفرع العملاء & 口 مديرفرع & $\begin{array}{l} \\
\end{array}$ & المستوى الوظيفي & $r$ \\
\hline & لـ لـ من ه سنوات & $\begin{array}{l}\square \\
\end{array}$ & من · ا سنوات & 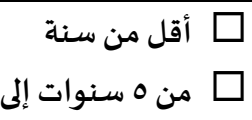 & سنوات الخبرة & $\varepsilon$ \\
\hline & & $\begin{array}{r}\square \\
\text { د } \quad \square\end{array}$ & & $\begin{array}{l}\square \\
\square \text { ماجستير } \quad \square\end{array}$ & المستوي التعليمي & 0 \\
\hline
\end{tabular}




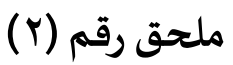

بيان بتوزيع أعداد المديرين والموظفين بفروع بنك القاهرة بمحافظة الأسكندربة (محل البحث)

\begin{tabular}{|c|c|c|c|c|c|c|c|c|c|c|c|}
\hline \multicolumn{6}{|c|}{ الموظقين } & \multicolumn{5}{|c|}{ المديرين } & \multirow{2}{*}{ اسم الفرع البيان } \\
\hline الإجمالي & مراقب & مصترفي & مشرف & مصرفي & مصرفي (ب) & للذاير فُرع & مدير فُرع & فرع & مدائب & ماير & \\
\hline$\varepsilon Y$ & 3 & 0 & V & 12 & 10 & 1 & 1 & 1 & 1 & 1 & فرع سيزوستريس \\
\hline$\varepsilon \cdot$ & 3 & 0 & 6 & 11 & 10 & 1 & 1 & 1 & 1 & 1 & فرع صلاح سالم \\
\hline$r \wedge$ & r & $r$ & $\varepsilon$ & V & Ir & 1 & 1 & 1 & 1 & 1 & فرع سبورتنج \\
\hline ro & r & $r$ & $\varepsilon$ & 7 & 1. & 1 & 1 & 1 & 1 & $T$ & فرع الإقبال \\
\hline Yr & $r$ & $r$ & $\varepsilon$ & 7 & 9 & 1 & 1 & 1 & 1 & 1 & فرع جليم \\
\hline rq & r & $r$ & 0 & $\wedge$ & 11 & 1 & 1 & 1 & 1 & 1 & فرع باكوس \\
\hline$r \mu$ & 1 & $r$ & $\varepsilon$ & 7 & 9 & 1 & 1 & 1 & 1 & 1 & فرع الورديان \\
\hline$r \wedge$ & $r$ & $\varepsilon$ & 0 & 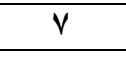 & 1. & 1 & 1 & 1 & 1 & 1 & فرع العجمي \\
\hline 14 & 1 & $r$ & 1 & $\varepsilon$ & 0 & 1 & 1 & 1 & 1 & 1 & فرع برج العرب \\
\hline $1 \varepsilon$ & 1 & $r$ & 1 & $\varepsilon$ & 7 & 1 & 1 & 1 & 1 & 1 & فرع باب سدرة \\
\hline$r \varepsilon$ & $r$ & 0 & $\varepsilon$ & $\Lambda$ & $1 \leq$ & 1 & 1 & 1 & 1 & 1 & فرع المنتزة \\
\hline $1 \varepsilon$ & 1 & 1 & $r$ & $\varepsilon$ & 7 & 1 & 1 & 1 & 1 & 1 & فرع الإبر اهيمية \\
\hline 1. & 1 & 1 & 1 & $r$ & $\varepsilon$ & 1 & 1 & 1 & 1 & 1 & فرع الأكاديمية البحرية \\
\hline $1 \varepsilon$ & 1 & 1 & r & $\varepsilon$ & 7 & 1 & 1 & 1 & 1 & 1 & فرع طريق الحرية \\
\hline \multicolumn{11}{|c|}{1} & مدير منطقة \\
\hline \multicolumn{11}{|c|}{$\mathrm{VI}$} & إجمالى أعداد المديرين \\
\hline \multicolumn{11}{|c|}{$r r v$} & إجمالي أعداد الموظفين \\
\hline \multicolumn{11}{|c|}{$\varepsilon \cdot \Lambda$} & الإجمالي العام \\
\hline
\end{tabular}

المصيدر: إعداد الباحث من خلامل المقابلات الشخصية 19 . 
ملحق رقم (r) تحديد حجم العينة

تحديا حجم الفيبة

\begin{tabular}{|c|c|c|c|c|c|}
\hline المهيتة & גור & العي & alian & ingen & chin \\
\hline 74 & $1 \% \ldots$ & 18 & $\%$ & 1. & 1. \\
\hline $74 \mathrm{~V}$ & $17 \ldots$ & 125 & $r+$ & 18 & 10 \\
\hline$r .7$ & $18 \ldots$ & $18 \mathrm{~A}$ & $7:$ & 14 & 7. \\
\hline $7 \cdot 7$ & $10 \ldots$ & $10 \%$ & To. & $7:$ & 70 \\
\hline$r ?$ & 17.0 & 100 & $7 \%$ & $\nabla \mathrm{A}$ & $r$. \\
\hline rit & $1 \mathrm{~V} \cdot$ & 104 & TV. & $r$ & $r a$ \\
\hline riv & $1 \mathrm{~A} \cdot \mathrm{.}$ & $17 \%$ & TA. & 79 & $2 \cdot$ \\
\hline$r \%$ & $14 .$. & 170 & 74. & 2 & is \\
\hline$r \%$ & $7 \ldots$ & 174 & $7 \ldots$ & $2 \mathrm{t}$ & o. \\
\hline$r \% \mathrm{~V}$ & 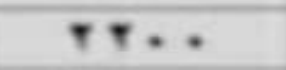 & $1 \mathrm{Va}$ & $r \%$ & $2 A$ & a a \\
\hline$r+1$ & $7: \ldots$ & IA & $r:$ & $\theta T$ & 7. \\
\hline$r r a$ & $7 \%$ & $1 \times 1$ & 78. & 07 & 70 \\
\hline$r r A$ & TA. & 141 & $\mathrm{rA}$. & 07 & $\mathrm{r} \cdot$ \\
\hline$r: 1$ & $r \ldots$ & 147 & $2 \ldots$ & 87 & $\mathrm{vo}$ \\
\hline$r: 7$ & $r a+$. & 7.1 & 27. & 78 & A. \\
\hline$r o s$ & $t \ldots$ & 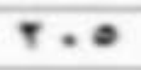 & 25 & $\mathbf{V}$. & $A \theta$ \\
\hline ros & $20 \ldots$ & $\%$ & 87. & $v r$ & 4. \\
\hline$r \otimes v$ & a... & 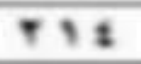 & $2 A$. & 87 & 40 \\
\hline 791 & $7 \cdot$. & $7 \mathrm{~V}$ & e.. & A. & $1 \cdots$ \\
\hline $79:$ & $\boldsymbol{r} \ldots$ & $7 \% 7$ & 00. & A 7 & 11. \\
\hline$r 9 \mathrm{~V}$ & A... & $7+\mathrm{t}$ & $7 \ldots$ & 47 & $1 \%$ \\
\hline 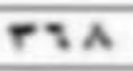 & $4 \ldots$ & $7 \leq 7$ & 70. & $4 \mathrm{~V}$ & 17. \\
\hline$r v \cdot$ & $\cdots$ & $T \leq \mathrm{A}$ & $\mathbf{r} \cdot$ & $1 \cdot \pi$ & 12 \\
\hline rVa & $10 \ldots$ & Ta $t$ & $\mathrm{ve}$ & $1 \cdot \mathrm{A}$ & 10. \\
\hline rVv & $7 \ldots$ & $7 \%$ & A.. & 137 & 17. \\
\hline rva & $r \ldots$ & $7 \%$ & A D . & IN & 18. \\
\hline rA. & t.... & 784 & $4 \ldots$ & $17 \%$ & NA. \\
\hline rA S & $\cdots$ & $7 \times t$ & 10. & $1 \% \mathrm{~V}$ & 14. \\
\hline rAT & $\mathrm{V} \boldsymbol{0} \ldots$ & $\mathrm{T} \vee \mathrm{A}$ & $\cdots$ & $17 \%$ & $7 \cdots$ \\
\hline$r A:$ & $1 \ldots \ldots$ & $\nabla \wedge \theta$ & $11 \ldots$ & 179 & $7 \%$ \\
\hline
\end{tabular}

